Universidade de São PAUlo

FACUldAde De FILOSOfia, Letras E CiênCIAS Humanas

$\&$

UNIVERSITÉ DE LIĖGE

FACUlté De Philosophie et LetTres

CAROLINA LINDENBERG LEMOS

\title{
CONDIÇÕES SEMIÓTICAS DA REPETIÇÃO
}

(Versão corrigida conforme a Resolução CoPGr6018)

São Paulo / Liège

2015 


\section{CAROLINA Lindenberg LEMOS}

\section{CONDIÇões SEMIÓticas da REPETIÇÃo}

(Versão corrigida conforme a Resolução CoPGr6018)

TESE APRESENTADA COM VISTAS À OBTENÇão DO TítUlo DE DOUTOR EM LiNGUística pela Faculdade de Filosofia, Letras e CiÊnCIAS Humanas Da Universidade DE São Paulo e de Docteur en Langues et LetTres pela faculté de Philosophie ET LetTRes da UniVERSitÉ DE LIĖGe NOS QUADROS DO ACORDO DE DUPLA TITULAÇÃO ASSINADO POR ESSAS INSTITUIÇÕES.

Área de Concentração: Semiótica e LingUística Geral / LANGUeS et LetTres

OrientAdores: Prof. DR. Luiz Augusto DE Moraes TAtit e Prof. Dr. SÉmir Badir

São Paulo / Liège

2015 
Nome: LINDENBERG LEMOS, Carolina

Título: Condições Semióticas da Repetição

Tese apresentada com vistas à obtenção do título de Doutor em Linguística pela Faculdade de Filosofia, Letras e Ciências Humanas da Universidade de São Paulo e de Docteur en Langues et Lettres pela Faculté de Philosophie et Lettres da Université de Liège nos quadros do acordo de dupla titulação assinado por essas instituições.

Área de Concentração: Semiótica e Linguística Geral / Langues et Lettres

Aprovada em: de janeiro de 2015

BANCA EXAMINADORA:

Prof. Dr. Luiz Augusto de Moraes Tatit

Universidade de São Paulo

Prof. Dr. Sémir Badir

Université de Liège / FNRS

Prof. Dr. Renata Ciampone Mancini

Universidade de Federal Fluminense

Prof. Dr. Waldir Beividas

Universidade de São Paulo

Prof. Dr. François Provenzano

Université de Liège 
Aos meus mestres

I teach straying from me, yet who can stray from me? I follow you whoever you are from the present hour, My words itch at your ears till you understand them. 


\section{Agradecimentos}

Esta tese deve sua história a mais gente do que posso nomear. Escolhi agradecer aqui as pessoas que participaram diretamente da pesquisa que me trouxe ao texto final.

Ao Prof. Luiz Tatit, por acompanhar minha trajetória de formação e me ajudar a trazer esta tese a cabo.

Ao Prof. Sémir Badir, por me inspirar e me ensinar, pela amizade e pelas aulas, pelos presentes e pelas trocas, enfim, por mais coisas do que posso nomear.

Aos professores Ivã Carlos Lopes e Waldir Beividas, que tão amplamente participaram da minha trajetória.

Ao Prof. François Provenzano, pelas trocas em Liège e por vir de tão longe para participar da banca de doutorado.

Aos professores José Luiz Fiorin, Claude Zilberberg e Jean-Marie Klinkenberg, cujas sugestões de leitura desencadearam saltos importantes.

À Prof ${ }^{a}$ Maria Giulia Dondero, pelo apoio acadêmico e pessoal na minha chegada a Bruxelas e depois. À Prof ${ }^{a}$ Elizabeth Harkot-de-La-Taille, pelo apoio acadêmico e pessoal antes e durante a estada na Bélgica. 
Aos professores e colegas Renata Mancini, José Roberto do Carmo Jr. e Lorenzo Cigana pelas discussões semio-glossemáticas.

A Yasmine Badir e Dany Danino, por abrirem tantas novas vias éticas, estéticas, artísticas e literárias que enriqueceram esta tese e meu mundo em geral.

Aos professores e colegas Evani Viotti, Ronald Beline e Mariana Luz P. de Barros, pela leitura de partes desta tese.

Ao Lucas Shimoda pelas ajudas com a formatação e ao Nelson Lago pelas consultas musicais.

À Érica Flávia de Lima, ao Robson Dantas Vieira e à Denise Cristiane Campos dos Santos, por ajudas incontáveis.

Aos professores Marcelo Cândido, Marc Delrez, Paola Moreno e, mais uma vez, Waldir Beividas e Sémir Badir, mas também a Regina Celi Sant'Ana e Catherine Dassis. Essas pessoas tornaram possível o acordo de dupla titulação entre a USP e a ULg.

Aos professores e colegas da USP e da ULg.

A Maria Paola Seixas Campos por ajudas pragmáticas.

A Jean-Michel Trauscht pelo apoio, pelas discussões instigantes, pelos gráficos e pelas traduções para o francês, mas sobretudo por topar a empreitada.

A Paulo, Helena, Letícia, Tomaz, Dora e Mila.

À CAPES e ao Banco Santander, pelas bolsas concedidas para esta pesquisa. 
Il est souvent plus aisé de découvrir une vérité que de lui assigner la place qui lui revient.

Ferdinand de Saussure 


\section{Resumo}

Trazida de áreas diversas dos estudos do homem, a repetição ganha papel central nesta tese de teor semiótico. Trata-se de fenômeno muito presente em todas as ações humanas e, em especial, nos textos. O caráter opcional de certas repetições nos textos traz à baila o problema de sua função, uma vez que, em certos casos, parece agir diretamente sobre o ritmo do conteúdo e o fluxo de entradas e saídas do campo de presença. Esse caráter regulador do ritmo divide a pesquisa em duas questões. De um lado, o efeito rítmico parece apontar para uma estrutura subjacente. Nesse sentido, podemos nos perguntar: qual é a configuração dessa estrutura? De que forma participa a repetição? Ou ainda, qual o seu lugar no esquema semiótico? De outro lado, a repetição parece envolver certa contradição: de que maneira um fenômeno que não traz novidades, apenas a retomada do conhecido, pode, por vezes, criar um efeito de tensão ou surpresa?

Para responder a essas perguntas, partimos de uma revisão do papel da repetição em duas áreas vizinhas: a retórica e uma determinada corrente linguística. Essa discussão nos permitiu enxergar insuficiências nessas abordagens que podem ser supridas pela semiótica. Uma vez dentro da perspectiva semiótica, buscamos o lugar ocupado pela repetição, confrontando-a com conceitos como identificação, texto, língua e a própria noção de semiótica. Estabelecida a posição da repetição no texto, passamos a levantar e discutir as condições textuais necessárias para o aparecimento 
de repetições relevantes. Além do processo de identificação, a noção de saliência, baseada na oposição figura e fundo, revelou-se central para a explicação do fenômeno. Finalmente, a linearidade mostrou-se relevante, o que nos permitiu rediscutir seu estatuto teórico como uma manifestação possível da estrutura sintagmática subjacente.

Tendo delineado as condições da repetição, iniciamos a investigação sobre os efeitos um tanto contraditórios que havíamos constatado nas ocorrências repetitivas. Vimos que a repetição pertence à ordem da extensidade — ela se conta, não se mede - , sendo assim, é instrumento de manifestação de um ritmo do conteúdo que lhe é pressuposto. Nesses termos, a repetição está subordinada a valências intensivas como o andamento e a tonicidade. Para assegurar a pertinência de nossos argumentos, estudamos a repetição no interior de objetos selecionados, nos quais está a serviço da estruturação textual. As análises dos objetos acabaram por evidenciar as relações da repetição com a concepção de aspecto, e três estilos de progressão textual ligados à repetição se confirmaram: o circular, o linear e o espiral.

Esse trajeto mostrou-nos em que termos a repetição se liga a uma estrutura subjacente e a manifesta, mas também de que forma essa estrutura não só explica, como gera as variações de ritmo e andamento que se fazem sentir por meio da repetição. As contradições aparentes dos efeitos da repetição se explicam pelas próprias bases epistemológicas da disciplina. O caráter analítico e relacional da semiótica está na base da construção repetitiva, que, sem acrescentar nada de novo, pode levar o enunciatário à tensão, ao clímax e à surpresa.

PALAVRAS-CHAVE: linguística; estrutura; texto; ritmo; tensividade; aspecto 


\section{Résumé}

Provenant de diverses disciplines des sciences de l'homme, la répétition prend un rôle central dans cette thèse $d$ 'inclination sémiotique. Il s'agit d'un phénomène très présent dans toutes les actions humaines et, particulièrement, dans les textes. Le caractère facultatif de certaines répétitions dans les textes met en exergue le problème de sa fonction, vu que, dans certains cas, elle semble agir directement sur le rythme du contenu et sur le flux d'entrées et de sorties du champ de présence. Ce caractère régulateur de la répétition vis à vis du rythme partage la recherche en deux fronts. D'un côté, l'effet rythmique semble pointer vers une structure sous-jacente. De ce point de vue, on peut se demander : quelle est la configuration de cette structure? De quelle manière la répétition y participe-t-elle ? Ou encore, quelle est sa place dans le schéma sémiotique ? D'un autre côté, la répétition semble impliquer une contradiction : de quelle manière un phénomène qui n'apporte pas de nouveauté, mais seulement une réitération du connu, peut-t-il, parfois, créer un effet de tension ou de surprise?

Pour répondre à ces questions, nous sommes partis d'une révision du rôle de la répétition dans deux domaines voisins : la rhétorique et un certain courant linguistique. Cette discussion nous permet de constater les insuffisances de ces approches et de comprendre de quelle manière elles peuvent être comblées par la sémiotique. À l'intérieur de la perspective sémiotique, nous avons investigué la place occupée par la répétition, en 
la contrastant avec les concepts d'identification, de texte et de langue et ainsi qu'avec la notion de sémiotique elle-même. Une fois la place de la répétition dans le texte établie, nous avons souligné et discuté les conditions textuelles nécessaires à l'apparition de répétitions pertinentes. En plus du processus d'identification, la notion de saillance, basée sur l'opposition figure et fond, s'est révélée centrale pour l'explication du phénomène. Finalement, la linéarité s'est montrée pertinente, ce qui nous a permis de rediscuter son statut théorique en tant que manifestation possible de la structure syntagmatique sous-jacente.

Ayant tracé les conditions de la répétition, nous avons commencé à examiner certains effets quelque peu contradictoires que nous avions observé dans les occurrences répétitives. On a vu que la répétition appartient à l'ordre de l'extensité — on la dénombre, on ne la mesure pas —; ainsi, elle est un instrument de la manifestation du rythme du contenu qui lui est présupposé. Dans ces termes, la répétition est subordonnée aux valences intensives, comme le tempo et la tonicité. Pour assurer la pertinence de nos arguments, nous avons étudié la répétition à l'intérieur de quelques objets choisis, où elle est au service de la structuration textuelle. Les analyses des objets ont permis de relever les relations que la répétition entretient avec la notion d'aspect et trois styles de progression textuelle liés à la répétition se sont confirmés : le circulaire, le linéaire et celui en spiral.

Ce parcours nous a montré en quels termes la répétition est reliée à une structure sous-jacente et en quoi elle en est une manifestation, mais aussi de quelle manière ladite structure non seulement s'explique, mais aussi génère, les variations de rythme et de tempo qui se font sentir à travers la répétition. Les contradictions apparentes des effets de la répétition s'expliquent par les bases épistémologiques mêmes de la discipline. Le caractère analytique et relationnel de la sémiotique est au cœur de la construction répétitive, qui, sans rajouter quoique ce soit de nouveau, peut amener l'énonciataire à la tension, au climax et à la surprise.

MOTS-CLÉS: linguistique ; struture ; texte ; rythme ; tensivité ; aspect 


\section{Abstract}

Emanating from different areas of the human sciences, repetition was given a central role in this thesis of semiotic inclination. It is a widespread phenomenon in all fields of human activity and, particularly, in texts. The optional character of certain repetitions brings about the problem of its function, since, in certain cases, it seems to act directly on the rhythm of the content and the flow of entrances and exits of the phenomenal field. This regulation of the rhythm divides the research into two fronts. On the one hand, the rhythmic effect points to an underlying structure. In that sense, one can ask: what is the configuration of such structure? In what way is repetition part of it? Or even, what is its place in the semiotic model? On the other hand, repetition seems to involve a certain degree of contradiction: in what way can a phenomenon that brings no novelty, only the resumption of the same, sometimes create an effect of tension or surprise?

In order to answer these questions, we undertake the revision of the role of repetition in neighboring fields: rhetoric and a specific trend in linguistics. This discussion has allowed us to detect a few insufficiencies in these approaches that may be answered by semiotics. From the semiotic perspective, we have explored the place occupied by repetition, by opposing it to concepts such as identification, text, language and to the notion of semiotics itself. Once the position of repetition in the text is established, we move 
on to note and discuss the textual conditions necessary to the occurrence of relevant repetitions. In addition to identification, the notion of salience, based on the opposition between figure and ground, revealed itself to be central to the explanation of the phenomenon. Finally, linearity has also proven relevant, which allowed us to re-discuss its theoretical status as one possible manifestation of the underlying syntagmatic structure.

Having outlined the conditions for repetition, we have started an investigation into the somewhat contradictory effects we had observed in repetitive incidents. We saw that repetition belongs to the order of the extent - it is counted, not measured - and, in being so, it is a tool for the manifestation of the rhythm of the content that is presupposed by it. In these terms, repetition is subordinated to the intensive sub-dimensions: tempo and tonicity. To ensure the relevance of our arguments, we studied repetition within some selected objects, where it is made to serve the structuring of the text. Finally, the analysis of these objects shed light on the relations between repetition and the concept of aspect, and three styles of textual progression related to repetition were confirmed: circular, linear and spiraling.

This path of investigation has shown us the terms which repetition is tied to and the way in which it manifests an underlying structure. It has also revealed that such structure not only explains but also generates the variations in rhythm and tempo that are felt through repetition. The apparent contradictions of the effects of repetition are explained by the very epistemological bases of the field. The analytical and relational aspects of semiotics are the basis for repetitive construction, which, without adding any new information, may lead the enunciatee to tension, climax and surprise.

KEYWORDS: linguistics; structure; text; rhythm; tensivity; aspect 


\section{Lista de Figuras}

2.1 Representações de análises . . . . . . . . . . . . . . . . . . 52

2.2 Representação de uma mutação . . . . . . . . . . . . . . . . 54

2.3 Representação de uma análise não-homogênea . . . . . . . . 58

2.4 Representação operacional de uma semiótica . . . . . . . . . 61

3.1 Submarino - sequência "filtro solar em comprimidos" . . 89

3.2 Submarino - sequência global . . . . . . . . . . . 93

3.3 Submarino - três palavras-objeto $\ldots \ldots \ldots . \ldots 93$

3.4 Orange . . . . . . . . . . . . . . . . 94

3.5 Percurso gerativo do plano da expressão . . . . . . . . . . . 103

3.6 Norman Rockwell — "The Gossips", 1948 . . . . . . . . . . 105

3.7 Sintaxe extensiva da repetição . . . . . . . . . . . . . . . 111

4.1 Esquema de paradas e continuações . . . . . . . . . . . 132

5.1 Esquema de paradas e continuações . . . . . . . . . . . . 174

5.2 Esquema da esfera de ação dos agentes do discurso . . . . . 176 


\section{Sumário}

Resumo vii

Résumé $\quad$ ix

Abstract $\quad$ xi

Lista de Figuras $\quad$ xiii

$\begin{array}{ll}\text { Introdução } & 1\end{array}$

0.1 Foco e Contexto . . . . . . . . . . . . . . . . 2

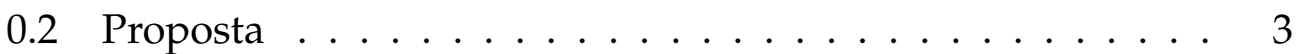

0.3 Organização e Direção . . . . . . . . . . . . . . . . . 4

1 Contextualização da Repetição na Retórica e na Linguística 9

1.1 O Lugar da Repetição na Retórica . . . . . . . . . . . . . . . . 12

1.2 Figuras de Repetição . . . . . . . . . . . . . . . . . . . 19

1.3 Crítica à Perspectiva de um Inventário de Formas . . . . . . 28

1.3.1 Forma vs. Conteúdo . . . . . . . . . . . . . . . . 29

1.3.2 Forma vs. Substância . . . . . . . . . . . . . . . 31

1.3.3 Imanência vs. Transcendência . . . . . . . . . . . . . 34

1.3.4 Indução, Contingência e Abertura . . . . . . . . . . 37

1.3.5 A Recusa do Sentido . . . . . . . . . . . . . . . . 39

1.4 Semiotização e Retorização . . . . . . . . . . . . . . . . . 42

2 O Lugar da Repetição na Semiótica Hjelmsleviana 48

2.1 Semiótica . . . . . . . . . . . . . . . . . . 50 
2.1.1 Definição de Texto . . . . . . . . . . . . . . . . . 61

2.2 Identidade . . . . . . . . . . . . . . . . . . 67

2.2.1 Semelhança . . . . . . . . . . . . . . . . 67

2.2 .2 Identificação . . . . . . . . . . . . . . . . . . . . 71

2.3 A Repetição na Semiótica Hjelmsleviana . . . . . . . . . . . 77

3 Condições Textuais para os Efeitos da Repetição $\mathbf{8 0}$

3.1 A Repetição como Fundo ou Figura . . . . . . . . . . . . 87

3.2 Da Relação Fundo-Figura ao Encadeamento Temporal . . . . 91

3.3 Considerações sobre a Noção de Linearidade . . . . . . . . . 95

3.3.1 Sintagma e Texto . . . . . . . . . . . . . . . . . 95

3.3 .2 Tempo e Leitura . . . . . . . . . . . . . . . . . . . 100

3.4 Contraste de Termos Relacionados . . . . . . . . . . . . 107

3.4 .1 Identificação e Linearidade . . . . . . . . . . . . . . 108

3.4.2 Identificação, Linearidade e Saliência . . . . . . . 110

4 Complexidade da Repetição 114

4.1 Manifestante e Manifestado . . . . . . . . . . . . . . . . . . 115

4.2 Extremos Especulativos . . . . . . . . . . . . . . . 117

4.3 Repetição e Isotopia . . . . . . . . . . . . . . . . . . . . . . 122

4.4 Estilo Tensivo . . . . . . . . . . . . . . . . . . . . . . . . . . . 129

4.5 A Espera . . . . . . . . . . . . . . . . . . . 133

4.6 Local e Global . . . . . . . . . . . . . . . . . . . . 136

5 Análises

Contraste entre Local e Global 141

5.1 Poesia - A Desconstrução de um Objeto em Valor . . . . . 143

5.1 .1 O Tom e o Gênero . . . . . . . . . . . . . . . . . . . 143

5.1 .2 A Progressiva Aproximação . . . . . . . . . . . . . . . 148

5.1 .3 O Tratamento das Figuras . . . . . . . . . . . . . 151

5.1 .4 Estrutura Involutiva . . . . . . . . . . . . . . . 154

5.2 Canção - Estudo das Emoç̃oes na Letra, na Música e na Voz 161

5.2.1 Organização Textual . . . . . . . . . . . . . . . . . 162

5.2.2 Os Grandes Ciclos da Narrativa de Miss Otis . . . . . 165 
5.2.3 Duas Formas de Emergência do Sentido . . . . . . . . 171

5.2.4 O Lugar da Enunciação . . . . . . . . . . . . . . . . . . . . . . . . . . . . . . . . . . . .

5.3 Balanço . . . . . . . . . . . . . . . . . . . 181

\section{Conclusão}

Referências

192

Anexo I

Poema(s) da Cabra

201

Anexo II

Miss Otis Regrets 


\section{Introdução}

No kind of reasoning is more common or more

useful - even necessary - to human life than

the kind derived from the testimony of men

David Hume 


\subsection{Foco e Contexto}

A repetição já foi tema de diversos trabalhos em diferentes áreas de estudos sobre o homem. Podemos encontrar textos clássicos inteiramente dedicados ao assunto, como Diferença e Repetição de Gilles Deleuze (2006) e "Recordar, Repetir e Elaborar" de Sigmund Freud (1981). No entanto, na semiótica, o que existe é, salvo engano, uma miríade de menções à repetição espalhadas por textos não diretamente dedicados ao assunto. O que buscamos é, dentro do alcance deste trabalho, trazer para o centro da discussão o fenômeno até aqui tratado de forma lateral da repetição.

Ao estudar a composição de elementos de expressão e conteúdo em publicidades televisivas durante o mestrado (Lemos, 2010), ficou-nos claro que elementos repetitivos desempenhavam papel estruturante nos anúncios. Vimos, por um lado, que a repetição contribuía para a coesão textual e, por outro lado, que estava associada a aumentos de tensão. Embora pudesse ser facilmente identificada a relação entre a repetição de certas porções do texto e o aumento de tensão, havia algo de contraditório nessa constatação. A repetição é a confirmação do esperado e normalmente a noção de impacto está associada ao inusitado (Zilberberg, 2008 e $2011 b$ : 163194). A fim de entender esse mecanismo de construção textual, passamos a cotejar o seu funcionamento com diversas ferramentas e certos pressupostos da linguística saussuriana e da semiótica francesa, incluindo os seus desdobramentos atuais (Zilberberg, 2011b; Tatit, 1997, 2007a, 2007b). 
Com o tempo, deparamos com outras ocorrências desse efeito da repetição. Vimos que a relação que havíamos descrito não se restringia aos tipos de textos que foram objeto de nossa dissertação. De fato, a repetição faz parte dos textos em geral. Contamos histórias plenas de repetições. Contamos muitas vezes as mesmas histórias. As nossas atividades cotidianas são em geral práticas rotineiras, repetitivas. Constatações como essas nos fizeram considerar, ao menos como hipótese, a repetição como uma verdadeira estratégia de produção do sentido. Retomamos, assim, o tema clássico para tirar-lhe novas consequências à luz de uma perspectiva semiótica, em especial dentro da episteme hjelmsleviana e sob o enfoque dos estudos sobre a tensividade nos textos.

\subsection{Proposta}

Afinal, de onde vem essa certeza de que a repetição é estruturante? Para Lévi-Strauss (1985), a "repetição tem uma função própria, que é a de tornar manifesta a estrutura do mito". Inspirados na formulação do antropólogo francês, passamos a buscar de maneira mais global a estrutura semiótica manifestada pela repetição nos textos, ou ainda, a estrutura semiótica que viabiliza a repetição nos termos descritos acima.

Essa perspectiva levanta uma série de questões. Primeiramente, é preciso discutir a opção pelo paradigma semiótico e destacar as vantagens que isso pode trazer para a abordagem da repetição em relação a áreas vizinhas. Uma vez justificada nossa escolha, percebemos que a repetição não tem um estatuto claro dentro da teoria e sem conhecer o seu lugar conceitual é 
quase impossível reconhecer os termos que lhe são comparáveis e a quais categorias está submetida. Não queremos dizer que o trabalho com esse tema seja uma grande novidade para a semiótica, mas, sim, que a definição do seu estatuto e o esclarecimento desse ponto colocarão os demais instrumentos teóricos em perspectiva. Outra questão proposta é a das condições e consequências de considerar esse mecanismo como estruturante. Por fim, precisamos entender como a repetição se insere na análise de texto, uma vez que a semiótica não é somente uma teoria do sentido, mas, igualmente, um projeto metodológico.

\subsection{Organização e Direção}

Para responder a essas perguntas, procedemos a um único movimento ainda que variado em sua expressão - de delimitação progressiva do fenômeno e de seu âmbito de pertinência. Como todo fechamento começa com uma abertura, nosso primeiro capítulo procura abarcar as perspectivas em que um estudo discursivo da repetição se mostre pertinente. Introduzimos a repetição nos quadros da retórica pela proximidade dos seus conceitos com os da semiótica, e fazemos um caminho na direção da linguística ao excluir o caráter prescritivo e inserir o descritivo. $\mathrm{O}$ tratamento dado por Madeleine Frédéric (1985) à repetição no interior dessas duas disciplinas nos oferece inventários detalhados de uso e do escopo da repetição no discurso. Tomamos o resultado de Frédéric como nosso ponto de partida e passamos à crítica do procedimento de inventariar e do próprio inventário que tínhamos em mãos. O levantamento das fragilidades dos inventários é, 
ao mesmo tempo, a introdução do enfoque semiótico. Nenhuma perspectiva dá conta de todas as facetas de um objeto e o olhar para os resultados de um sob a luz de outra teoria só pode abrir o campo para os caminhos que ainda faltam trilhar. Assim, a crítica se transforma numa introdução ao ponto de vista semiótico e justifica os desdobramentos realizados nos capítulos seguintes. Fechamos o capítulo inicial com a possibilidade, já entrevista por semioticistas contemporâneos, de trazer para o âmbito da semiótica a preocupação com a "impropriedade fundadora do sentido" expressa inicialmente na oposição próprio vs. figurado - e na centralidade da ênfase, hoje tão cara à semiótica tensiva, mas também no tratamento "semiotizante" dos objetos da retórica. Nossa contribuição passa a ser então a incorporação à semiótica do conhecido objeto retórico da repetição por meio da busca do regime figural que a subsume e das condições semióticas de seu surgimento.

Se o primeiro capítulo busca, nas disciplinas vizinhas, a abrangência da repetição, o capítulo segundo iniciará o processo de definição do fenômeno no interior da semiótica. Nos quadros da chamada Escola de Paris, a própria noção de semiótica é por vezes tomada por evidente e suas especificidades não são declaradas. Por outro lado, se estamos de acordo que os conceitos de Hjelmslev formam a base epistemológica, nem sempre tiramos todas as consequências dessa filiação. Assim, começamos o capítulo escandindo a definição de semiótica que se encontra no Résumé d'une théorie du langage (Hjelmslev, 2010) e, em seguida, abordando o que se entende por texto no interior dessa definição. Os conceitos aí levantados são essenciais para a discussão que segue, mas serão também retomados 
aqui e ali em toda a tese a fim de estabelecer a ligação de cada parte com a teoria de base. Nesse ponto, passamos a investigar, a partir das noções de identidade e identificação, o lugar teórico da repetição no esquema hjelmsleviano. Chegamos assim à conclusão que, se as categorias da língua são condição para a constatação do fenômeno, a repetição em si já está no texto. Propomos entender a operação de identificação, que reconhece dois ou mais elementos como sendo o mesmo, como o liame entre língua e texto.

A configuração do conceito continua no Capítulo 3, no qual investigamos as condições em que a repetição observada afeta a espera e o ritmo do conteúdo. Se, no capítulo anterior, tínhamos estabelecido que a identificação é um dos fatores relevantes, as etapas seguintes mostram a importância da saliência - explorada por meio da noção de fundo e figura da Gestalt — e da linearidade — tida como a manifestação de um princípio sintagmático que lhe é logicamente anterior. Encerramos essa etapa com a comparação de termos próximos à repetição, como redundância, série, imitação, reprodução, e mostramos, em cada caso, que um dos três aspectos levantados identificação, saliência e linearidade - está ausente. No final, optamos pela manutenção do termo "repetição" que, devidamente configurado, descreve melhor o fato estudado.

O Capítulo 4 se lança na empreitada de investigar o efeito da repetição sobre o fluxo textual. Após esclarecer os limites dessa proposta a partir da ideia de que a repetição é uma estratégia possível para a criação da espera e a espera, um efeito possível da repetição, abordamos casos extremos de identidade total ou ausência completa de identidade para mostrar de que maneira a repetição geradora de ritmo depende do andamento, da tonici- 
dade, do tempo e do aspecto. Discutimos as flutuações de estilo tensivo da repetição que, de início, é descendente com a confirmação do esperado, mas que muda de direção pelo excesso de permanência num único estado, gerando assim, da atonia esperada, a surpresa tônica. As delimitações das fronteiras de mudança de estilo nos levam de volta ao aspecto e daí passamos a discutir o papel da repetição no modo de progressão textual.

Centrado nas análises, o Capítulo 5 inverte as prioridades a fim de mostrar a inserção deste estudo nas análises práticas. É por isso que a repetição não é tomada como centro de cada uma das duas análises, mas se revela num mecanismo bastante central para a construção dos sentidos nos textos. Ao final, voltamos aos modos de progressão textual que havíamos comentado no capítulo anterior para mostrar de que forma um modo espiral de progressão, ao mesmo tempo circular e linear, organiza o desenrolar do(s) "Poema(s) da Cabra” de João Cabral. Já em “The Hollow Men”, de T.S. Eliot reconhecemos um caráter principalmente circular nas repetições, pois, nesse caso, elas se manifestam, mas são abandonadas para dar lugar a outras não claramente ligadas às primeiras. Por fim, retomamos a análise da canção "Miss Otis regrets" de Cole Porter, na qual observamos uma repetição englobante de todo o texto e de certa forma dirigida, o que nos levou a considerá-la linear.

Sendo assim, notamos que a construção discursiva desta tese segue também os fluxos tensivos de abertura e fechamento. Iniciamos nosso trabalho com a abertura das perspectivas linguístico-discursivas globais, 
focalizamos paulatinamente o campo em torno da figura da repetição e, por fim, relançamos o nosso objeto na continuidade dos textos. Se estivéssemos preocupados com a chegada, talvez disséssemos que terminamos no lugar de onde saímos, mas como os heróis de contos maravilhosos, acreditamos que a repetição chega ao fim de nosso trajeto modificada. 
1

\section{Contextualização da Repetição na}

\section{Retórica e na Linguística}


Conforme apontamos na introdução, muitas áreas das humanidades se ocuparam direta ou marginalmente da repetição. Uma das disciplinas que estudou largamente os fenômenos repetitivos na linguagem foi a retórica. As diversas modalidades de repetição na linguagem estão dispersas nos manuais dessa disciplina, embora com pouca regularidade e baixa sintonia entre as opiniões dos autores (Frédéric, 1985:XV; 6-12). Ainda assim, pela extensão do material e pelos anos de reflexão na área, ${ }^{1}$ a retórica se revela um campo rico no levantamento de estruturas, tipos, classificações e intuições sobre o tema. Para os estudiosos da semiótica francesa, ela ainda traz uma pertinência especial por ter sido a primeira disciplina do discurso. Barthes (1970:173) afirmava que a retórica é uma metalinguagem cuja linguagem-objeto é o discurso - em suas palavras, "um discurso sobre o discurso". O Dicionário de Semiótica (Greimas \& Courtés, 2011 : 421) trata desse mesmo caráter precursor da retórica ao apresentá-la como "uma espécie de teoria do discurso pré-científica". Esse caráter pré-científico parece estar ligado ao fato de a retórica ser uma técnica de produção e não um instrumento de análise:

a retórica [aristotélica] é uma techné (ela não é uma empiria), ou seja: $o$ meio de produzir uma das coisas que podem indiferentemente ser ou não ser, cuja origem está no agente criador, não no objeto criado: não há techné das coisas naturais ou necessárias: o discurso não faz parte nem das primeiras, nem das últimas. $^{2}$ (Barthes, $1970: 179$ )

\footnotetext{
${ }^{1}$ Barthes (1970: 173), excluindo as vertentes orientais, reconhece uma tradição que vai do século $\mathrm{V}$ a.C. até o século XIX de nossa era.

${ }^{2}$ Tradução nossa para: "la rhétorique [aristotélicienne] est une techné (ce n'est pas une empirie), c'est-à-dire: le moyen de produire une des choses qui peuvent indifféremment être ou n'être pas, dont l'origine est dans l'agent créateur, non dans l'objet créé: il n'y a pas de
} 
A linguística e a semiótica vão tomar esse mesmo objeto da retórica - o discurso - e dar-lhe um tratamento mais científico, no sentido de colocar o teórico no polo do observador, do analista e não do prescritor.

Barthes aponta ainda que o momento de maior inserção da retórica no ensino é também o momento em que perde sua força no campo intelectual:

A retórica é triunfante: ela reina sobre o ensino. A retórica é moribunda: restrita a esse setor, ela cai, pouco a pouco, num descrédito intelectual. Esse descrédito é trazido pela promoção de um valor novo, a evidência (dos fatos, das ideias, dos sentimentos), que se basta em si mesma e que independe da linguagem (ou crê ser independente), ou ao menos tem a pretensão de apenas utilizá-la como um instrumento, uma mediação, uma expressão. ${ }^{3}$ (Barthes, 1970 : 192)

Ora, a valorização da evidência dos fatos em detrimento da linguagem usada para expressá-los, fator responsável pelo descrédito da retórica, é também o que aparece agora como justificativa para a revitalização da antiga arte do bem dizer. Ao tomar a posição de observador, o linguista trata a linguagem como um fato a ser descrito e explicado. Cai o elemento prescritivo e surge o caráter descritivo e explicativo da linguagem. Naturalmente que se descreviam línguas antes do advento da linguística. Esta traz, entretanto, um caráter de cientificidade aos estudos da linguagem. A

techné des choses naturelles ou nécessaires: le discours ne fait donc partie ni des unes ni des autres."

${ }^{3}$ Tradução nossa para: "La rhétorique est triomphante: elle règne sur l'enseignement. La rhétorique est moribonde: retreinte à ce secteur, elle tombe peu à peu dans un grand discrédit intellectuel. Ce discrédit est amené par la promotion d'une valeur nouvelle, l'évidence (des faits, des idées, des sentiments), qui se suffit à elle-même et se passe du langage (ou croit s'en passer), ou du moins prétend ne plus s'en servir que comme d'un instrument, d'une médiation, d'une expression." 
retórica voltará então à luz nos estudos semióticos e em outras teorias do discurso tributárias da linguística moderna, mas com as devidas mudanças de perspectiva, como atesta o Dicionário de Semiótica:

O interesse atual pela retórica explica-se pelo reaparecimento, sob o impulso da semiótica, da problemática do discurso. Se bem que não possam, por razões evidentes, ser integrados tais quais na semiótica discursiva, certos campos teóricos da antiga retórica correspondem às preocupações atuais e merecem ser explorados. (Greimas \& Courtés, $2011: 421)$

Um dos fatores cruciais para sua retomada pelos estudos discursivos é que a retórica aristotélica já insere a noção de um agente produtor do discurso. Também nesse aspecto, procurou-se uma via mais descritiva. Se, para a retórica clássica, o agente é aquele que recebe uma série de instruções para a boa construção de textos, para os estudos do discurso, ele é entendido como um enunciador: instância teórica pressuposta, cuja presença se faz sentir por marcas no texto (Fiorin, 2014:16).

\subsection{O Lugar da Repetição na Retórica}

A imagem que comumente associamos à retórica a partir do que nos chega pelas vias da escola é a de um paradigma de formas, uma lista de figuras. Entretanto, a origem da retórica como campo de estudo está no arranjo sintagmático das partes do discurso e do processo de sua elaboração (Barthes, 1970 : 175-176). Assim, a retórica contava três partes sucessivas, cada uma 
com suas subdivisões: inventio, dispositio, elocutio. ${ }^{4}$ Não cabe aqui discutir a fundo cada uma das partes, pois o nosso objetivo é tão somente delimitar o lugar da repetição nesse esquema. Em poucas palavras, a inventio trata da descoberta ou extração dos argumentos a partir de certas tópicas: os lugares comuns ou os lugares especiais, próprios a determinados assuntos. A dispositio, passo seguinte na construção argumentativa, é o arranjo ou a organização dos argumentos nas grandes partes do discurso - algo próximo ao que ainda temos hoje na ideia de uma introdução, um desenvolvimento e uma conclusão em textos dissertativos. ${ }^{5}$ Terceira e última fase, a elocutio é a própria textualização ou o "colocar em palavras". Os tropos e as figuras perfazem uma das partes da elocutio: a electio - a seleção de palavras e figuras que vão compor a textualização. E é em meio a essas figuras que se encontram as figuras de repetição (Fiorin, 2014 : 109-140).

Segundo Genette (1970 : 159), há uma progressiva redução do que entendemos por retórica da antiguidade aos nossos dias causada: primeiro pelo paulatino desaparecimento dos gêneros deliberativo e epidítico; em seguida por um desequilíbrio entre as partes, restando apenas a elocutio. Barthes (1970 : 182) trata igualmente dessas duas reduções:

Última aventura da retórica aristotélica: sua dissolução por sincretismo: a Retórica deixa de se opor à Poética, em favor de uma noção transcendente, que nós chamamos hoje de "Literatura"; ela não constitui mais apenas um objeto de ensino, mas torna-se uma arte (no

\footnotetext{
${ }^{4}$ Para uma visualização arbórea das partes da retórica, ver Barthes (1970 : 226).

${ }^{5}$ Barthes (1970 : 176) aponta que está, de fato, na repartição do discurso a origem das divisões da dissertação escolar (introdução, corpo demonstrativo, conclusão). No entanto, essa filiação não é explorada nos bancos escolares em geral.
} 
sentido moderno); ela passa a ser ao mesmo tempo uma teoria do escrever e um tesouro das formas literárias. ${ }^{6}$

Vê-se, portanto, que o caminho que leva à redução de três grandes partes, com suas subdivisões, à persistência quase exclusiva de uma última subparte (os tropos e figuras da electio) não é sem consequências. É curiosa a afirmação de Barthes de que a retórica se torna mais restrita, se ao mesmo tempo ela se expande para ocupar toda a literatura. Entramos aí num certo "paradoxo" da significação no qual quanto mais abrangente é um termo, um campo, um domínio, menos ele "significa": uma palavra que significa tudo não significa nada (ou muito pouco):

Um aumento no número de termos na estrutura faz aumentar o intervalo entre os extremos e torna mais fina a determinação da intensão; e quando se aumenta o inventário de propriedades ligados à determinação descritiva (intensional), temos uma diminuição concomitante das extensões vinculadas a elas, já que quanto mais propriedades temos, menos termos existem capazes de satisfazê-las. [...] Assim, a riqueza semântica aumenta no sentido inverso ao da extensão. Quanto mais um objeto é carregado de significações, mais ele é individualizado. (Lopes, 2004 : 45-46)

Lopes descreve nesse trecho a especificação por que passa um termo à medida que é colocado em oposição a um número maior de termos numa

\footnotetext{
${ }^{6}$ Tradução nossa para: "Dernière aventure de la rhétorique aristotélicienne: sa dilution par syncrétisme: la Rhétorique cesse de s'opposer à la Poétique, au profit d'une notion transcendante, que nous appellerions aujourd'hui 'Littérature'; elle n'est plus seulement constituée en objet d'enseignement mais devient un art (au sens moderne); elle est désormais à la fois théorie de l'écrire et trésor des formes littéraires."
} 
escala. Esse é o processo por que passou a retórica num primeiro momento em que seus quadros foram se estendendo e detalhando, cada vez com mais nuanças tanto nos procedimentos quanto nas figuras. É justamente o oposto dessa individualização que ocorreu com a retórica no momento em que se tornou mais abrangente. Para ilustrar o polo inverso, podemos citar palavras como "coisa", cuja primeira definição no Michaelis Moderno Dicionário da Lingua Portuguesa ${ }^{7}$ é bastante vaga: "tudo o que existe ou pode existir". Podemos mencionar ainda o verbo "get" em inglês, que conta oito entradas e uma série de subentradas no Oxford English Dictionary, ${ }^{8}$ com definições aparentemente opostas como: "experienciar, sofrer" e "induzir alguém a fazer alguma coisa", a primeira mais passiva e a segunda ativa. É difícil dizer a que se opõe uma palavra que é "tudo o que existe" ou uma outra que tem traços ao mesmo tempo ativos e passivos. Algo semelhante pode acontecer com as teorias. Veremos mais abaixo que a generalização excessiva de uma teoria acaba por fazer com que se torne menos explicativa, uma vez que generalizações levam à perda de diferenciações importantes, algo que se passou com a retórica num dado momento

Genette (1970:159-160) vê nos manuais de retórica a continuidade das reduções no que se entende por essa teoria pois, a partir do século XVIII, eles tratam exclusivamente da relação e da diferença entre figuras e tropos. O surgimento de manuais centrados nesse aspecto coloca a oposição próprio vs. figurado no centro das preocupações da retórica. O termo geral que reúne tropo e figura é ornamento, noção que sugere que há, por

\footnotetext{
${ }^{7}$ Foi utilizada a versão on-line disponível em: http://michaelis.uol.com.br/moderno/portugues/

${ }^{8}$ Foi utilizada a versão on-line disponível em: http:/ /www.oxforddictionaries.com/
} 
oposição, uma linguagem não ornada: o sentido próprio. $\mathrm{O}$ ornamento representa uma distância em relação ao sentido primeiro, uma animação à linguagem antes inerte. Segundo Barthes (1970:217-219), a oposição próprio vs. figurado é tributária da noção de sinonímia na língua. A perspectiva de escolha que reside na electio existe graças à possibilidade de substituição de um termo por outro e revela, dessa maneira, novos sentidos na forma de conotações. A ideia de substituição ou conversão é a própria noção de tropo, que, para não se confundir com a figura, ganha um sentido mais estrito de substituição de uma unidade, enquanto a figura se define como uma conversão que se dá num sintagma.

O alçamento a primeiro plano da oposição próprio vs. figurado contribui para reduzir a retórica de seu caráter inicialmente sintagmático, com dimensões paradigmáticas (como a seleção dos lugares comuns e especiais da inventio e a própria escolha de palavras da electio), à exclusiva paradigmática das taxonomias:

Aqui está então o tropo instalado no coração paradigmático daquilo que é apenas uma teoria das figuras mas, por causa de uma carência lexical singular e aparentemente universal, continuará ainda assim a se chamar retórica: belo exemplo de sinédoque generalizante. ${ }^{9}$ (Genette, $1970: 160)$

A verve redutora não para aí. Com a classificação sugerida por Dumarsais, propõe-se uma subordinação entre os ornamentos. Essa subordinação

\footnotetext{
${ }^{9}$ Tradução nossa para: "Voici donc le trope installé au cœur paradigmatique de ce qui n'est plus qu'une théorie des figures mais, par l'effet d'une carence lexicale singulière et apparemment universelle, continuera néanmoins de se nommer rhétorique: bel exemple de synecdoque généralisante."
} 
pressupõe que há ornamentos mais gerais e seus subtipos, ou que, de alguma maneira, seria possível reduzir o grande número de ornamentos a alguns tipos que abarcariam todos os que the são familiares por uma característica ou outra. Fontanier, ao marcar a diferença entre tropo e figura, elege o primeiro como modelo do segundo: o princípio passa a ser tropo vs. não-tropo. Essa divisão, por ser tão geral, talvez não deixe clara a direção dessa redução, mas podemos vê-la rapidamente ilustrada pelo caminho traçado por Genette (1970:160-166) de Vossius até a retórica de nossos dias. Vossius elege quatro figuras principais: metáfora, metonímia, sinédoque e ironia. Dumarsais aproxima a sinédoque da metonímia, considerando ambas como presididas pelo mesmo princípio de relação ou ligação. Fontanier exclui a ironia, considerando-a uma mera "figura de expressão" e não uma verdadeira figura de retórica. Vemos assim de que forma a retórica já reduzida aos tropos passa a figurar como dois termos opostos: metáfora e metonímia. Esse par ganhará uma dimensão bastante generalizada no texto "Dois Aspectos da Linguagem e Dois Tipos de Afasia", de Jakobson (2010), que aproxima essas figuras dos eixos paradigmático e sintagmático da língua. O caminho de redução examinado por Genette termina no início do século XX com a "sobrevivência milagrosa" da metáfora. Podemos somar a essa trajetória, a generalização da metáfora para além do discurso poético ou figurado. O trabalho de Lakoff \& Johnson (2002), Metáforas da Vida Cotidiana, vê num princípio metafórico geral o nascimento de toda a multiplicidade de sentidos expressos na língua a partir de sentidos topológicos de base. ${ }^{10}$

\footnotetext{
${ }^{10}$ Essa extrapolação é também prevista, ainda que criticada, por Genette $(1970: 169)$.
} 
As figuras que envolvem a repetição estão ainda a um passo do último movimento redutor que descrevemos. Se, por um lado, elas estão restritas à electio e se deixam reconhecer como pertencentes a um subgrupo - afinal, dizemos "figuras de repetição" —, não é o caso de absorvê-las nessas grandes figuras. Preferimos tratá-las aqui como um grupo separado dos demais ornamentos, mas já reunidas na categoria mais geral da repetição.

As reduções levadas ao extremo descrito borram diferenças que se viam inicialmente no detalhe meticuloso dos manuais, como previsto no estudo de Lopes. Por outro lado, elas estabelecem ligações e trazem à luz regularidades onde uma lista desordenada não permitiria, como ilustram os trabalhos de Jakobson. Essa afirmação de que um recorte pode ampliar a visão de um fenômeno poderia ser tomada como contraintuitiva no sentido de que toda análise é necessariamente uma redução, pois, ao fazer escolhas, deixamos de lado outros aspectos não contemplados pelo nosso viés. Esse é o mal de tornar discreto aquilo que antes era contínuo. No entanto, essa parece ser a única forma que temos de conhecer um objeto. Há sempre pelo menos um corte, uma primeira divisão. ${ }^{11}$ Desse corte dizemos ser um ponto de vista, justamente aquilo que nos permite ver certas características. É assim que Lakoff \& Johnson puderam transpor os limites da poética para o discurso comum e encontraram uma nova formulação para as abstrações e os graus de semelhanças que estão na língua. É assim também que é possível falar em figuras de repetição, ou seja, que é possível reunir a

\footnotetext{
${ }^{11}$ Para uma discussão do papel da análise como caminho do conhecimento de um objeto, ver Capítulo 2, mas principalmente Badir (2014:96 e ss.). Em breves palavras, a análise funda o objeto: na imensa massa dos fatos e coisas do mundo, o nosso olhar opera um primeiro recorte que reconhece um dado qualquer como distinto do resto, eis a primeira análise.
} 
reduplicação, a anáfora, o quiasmo, o ritornelo, a paráfrase — para citar algumas — sob essa grande categoria.

\subsection{Figuras de Repetição}

Acerca dos tratados de retórica antigos ou mais recentes, Barthes (1970 : 218219) fala de um furor taxonômico ("rage taxinomique"), fruto da tentativa de apreender a fala (e não apenas a língua):

a retórica tenta codificar a fala (e não mais a língua), ou seja o próprio espaço onde, em princípio, o código termina. [...] É na medida em que a Retórica antecipou uma linguística da fala (que não estatística), o que é uma contradição de termos, que ela se deu ao trabalho de abarcar numa rede cada vez mais fina das "maneiras de falar", o que seria tentar domar o indomável: a própria miragem. ${ }^{12}$ (Barthes, $1970: 219)$

Se essa paixão pela classificação parece “bizantina” àqueles que não participam da prática, Barthes $(1970: 195)$ aponta que, em toda escolha taxonômica, há uma opção ideológica, ou seja, há algo em jogo por trás do lugar dado às coisas.

Conforme veremos, o livro de Madeleine Frédéric (1985) — La répétition: Étude linguistique et rhétorique — não escapa disso. Na parte do livro

\footnotetext{
${ }^{12}$ Tradução nossa para: “la rhétorique essaye de coder la parole (et non plus la langue), c'est-à-dire l'espace même où, en principe, cesse le code. [...] C'est dans la mesure où la Rhétorique a préfiguré une linguistique de la parole (autre que statistique), ce qui est une contradiction dans les termes, qu'elle s'est essoufflée à tenir dans un réseau nécessairement de plus en plus fin les "manières de parler", ce qui était vouloir maîtriser l'immaîtrisable: le mirage même."
} 
dedicada à retórica, a autora aponta, como mencionamos acima, a pouca regularidade e interseção entre os retores e o fato de que as diversas modalidades de repetição estão dispersas nos tratados. Seu objetivo é, portanto, o de reunir num único trabalho todos os tipos de repetição identificados, criando assim um inventário e uma otimização das diferentes modalidades de repetição na retórica. A falta de regularidade não é uma particularidade das figuras de repetição e as classificações nos tratados podem até ser contraditórias (Barthes, 1970 : 219), mas o que traz Frédéric é justamente um certo viés: são as figuras de repetição que a autora escolhe colocar no centro de seu estudo retórico.

Frédéric (1985:27) organiza as figuras de repetição em dois grandes grupos: figuras determinadas pela forma e figuras determinadas pela semântica. Essa divisão está baseada numa oposição entre forma e conteúdo. ${ }^{13}$ Em poucas palavras, para Frédéric, a determinante formal diz respeito à extensão sintagmática (fonema, lexema, construção sintática). A determinante semântica trata de uma figura principal que vê um certo conteúdo semântico repetido sem determinação clara de sua extensão sintagmática. O critério semântico é definido pela negativa, ou seja, aquilo para que não se consegue estabelecer um limite sintagmático será relegado à semântica. Isso porque já nas figuras formais o elemento semântico está de fato presente, pelo menos a partir do nível dos morfemas, uma vez que estamos tratando de signos e não apenas de elementos de expressão (rimas,

\footnotetext{
${ }^{13}$ Essa oposição é um tanto alheia aos estudos de inclinação hjelmsleviana, como esta tese, que reconhecem uma forma da expressão e outra do conteúdo (Hjelmslev, 2003 : 5364). Desenvolveremos paulatinamente as dificuldades que a autora encontra nessa divisão, o que - esperamos - esclarecerá nossa escolha pela oposição do linguista dinamarquês.
} 
assonâncias, etc.).

Em última instância, todo o estudo retórico existe em função do sentido, haja vista que apenas as repetições do discurso construído, "com possíveis efeitos", são consideradas verdadeiras figuras e, portanto, contempladas nos inventários (Frédéric, 1985 : 78). Fiorin (2014:10), na aproximação que faz entre as figuras de retórica e a semiótica discursiva, reconhece essa tendência de estabelecer classificações pela forma, deixando de lado os efeitos produzidos: "O problema é que a figura era apresentada como uma operação formal, sem que se mostrasse que sentido ela criava. As formas da língua existem para produzir sentidos." A própria Madeleine Frédéric aponta que "a forma está sempre à disposição do sentido", ainda que não se possa atribuir uma significação única a uma figura, visto que desempenhará diferentes funções em contextos distintos. Ainda assim, a autora identificará os critérios de classificação dos retores sobretudo com base na extensão sintagmática da repetição (se toca alguns sons, um morfema, uma palavra ou todo um sintagma) ou na posição da repetição no interior da palavra, no sintagma ou no verso. Alguns critérios secundários são a ordem dos elementos repetidos, o número de elementos retomados, a integralidade ou parcialidade da repetição. Por fim, ela reconhece também os critérios semânticos da causa e do efeito de uma dada repetição (Frédéric, $1985: 16)$.

Assim, em linhas gerais, a parte relativa à retórica se organiza numa lista de figuras categorizadas pela extensão sintagmática. Cada entrada contém uma figura com breve explicação de como se constitui e exemplos numerados. Aqui e ali encontramos, em meio às listas, alguns comentários 
sobre a estrutura e o papel de uma dada repetição, mas essas observações que, a nosso ver, poderiam esclarecer o sistema que organiza as figuras de repetição num conjunto único ficam em segundo plano, como notas e comentários acessórios. Um exemplo pode ser encontrado nos comentários à figura de repetição número 30: reduplicação. Frédéric (1985:58) menciona aí os limites da classificação da repetição em função da posição. É importante notar o lugar em que essa crítica aparece no texto. Ela não está nem no início da seção, que trata das figuras baseadas no critério da posição, nem ao final, mas vem inserida nos comentários sobre a figura que a autora considera ser o limite de pertinência desse critério. Entende-se a escolha de fazer a crítica nesse ponto, em decorrência da posição de fronteira da figura da reduplicação, onde o critério perde sua pertinência. Embora ainda organize as figura que se seguem, o critério da posição se mostra insuficiente para classificá-las. No entanto, a falta de destaque e a colocação da crítica em meio a definições e exemplos revela a pouca importância que a autora parece lhe atribuir. Os objetivos de Frédéric estão mais fortemente dirigidos à constituição de uma lista tão exaustiva quanto possível, do que à depreensão das regras e dos limites que fundam esse sistema.

À guisa de conclusão de sua incursão pelo domínio da retórica, Frédéric (1985:79-80) organiza da seguinte forma o inventário de figuras de repetição:

A. Repetição de som:

i. simples (termos com a mesma flexão, assonância, rima; muitos sons semelhantes numa mesma palavra, sem atingir a sua 
totalidade)

ii. associado a um parentesco semântico (mesma raiz com flexões diferentes)

B. Repetição de palavra:

i. repetição com modificação do sentido (polissemia; sentido próprio vs. sentido figurado)

ii. repetição sem alteração do sentido (várias, mas por exemplo, o refrão)

C. Repetição de um tipo de construção ou um número de sílabas (extensão maior que a palavra)

D. Repetição de um conteúdo semântico por meio de palavras diferentes

E. Retomada depois de um desenvolvimento ou digressão

F. Convergência de mais de um desses tipos num mesmo texto

Essa síntese do extenso repertório construído pela autora nos confirma a presença constante do componente semântico, a despeito do fio condutor da extensão sintagmática. Para além dessa nossa observação, a autora tira duas conclusões gerais acerca de seu percurso pela retórica. Por um lado, os retóricos não levam em conta o discurso espontâneo, mas apenas o discurso "construído", deixando assim de fora certos casos de repetição na língua que não são "verdadeiras" figuras. Nesse mesmo sentido, também não são contempladas as repetições não estilísticas como a tautologia, a epanalepse e o pleonasmo. Por outro lado, a falta de sistematicidade dos 
retóricos, a inconstância de suas terminologias e a falta de um estudo centralizado na repetição fez com que esse tipo de figura se encontrasse largamente espalhado nos manuais e com uma multiplicidade de nuanças, que só a ausência de um elemento concentrador (dado pelo estabelecimento da repetição como tema central) permite construir. Assim, é esse caráter inconstante e assistemático que se torna na verdade o grande responsável pela riqueza do inventário.

É, no entanto, a primeira crítica - a da ausência de certas repetições que possibilitará a extensão desse inventário na segunda parte do livro em que a autora trata da repetição na linguística. O estilo de inventário permanece o mesmo, mas a inclusão de novos tipos de repetição vai complexificar a tipologia, revelando, potencialmente, um ponto de vista diferente em relação ao fenômeno. A tipologia segundo critérios linguísticos se organiza da seguinte forma (Frédéric, $1985: 125-230):^{14}$

I. Repetições involuntárias: patológicas, hesitação

II. Repetições inconscientes: do tipo "e então", pleonasmo vicioso

III. Repetições lexicalizadas: bárbaro, murmurar e aliterações lexicalizadas

\section{Repetições deliberadas}

\footnotetext{
${ }^{14}$ Note-se que a lista de figuras da retórica se inicia com letras maíusculas, enquanto a lista baseada na linguística começa com algarismos romanos maiúsculos e as letras maiúsculas estão no primeiro subnível. Essa escolha de numeração é nossa e procura refletir os níveis de subordinação de cada lista, ou seja, a segunda lista conta com um nível superior e mais abrangente que engloba o primeiro nível da divisão retórica. Desenvolveremos em mais detalhes a oposição entre as duas taxonomias abaixo.
} 
A. Repetição formal: categorias da expressão e categorias gramaticais

i. Repetição gráfica e tipográfica: "rima para os olhos" (Frédéric, $1985: 131)$

ii. Repetição fônica: aliteração, assonância, rima, anagramas, homofonia

iii. Repetição lexical:

a. extensão: palavra, sintagma, frase, grupo de frases

b. lugar: contíguo ou não, com separação tipográfica

c. ritmo: quando há uma certa ritmização da recorrência, como no refrão

d. repetição de dois ou mais grupos que se unem ou se distanciam no texto.

iv. Repetição sintática: espécie de molde sintático reiterado

v. Repetição suprassegmental: repetição de pausas, acentos, sílabas

vi. Convergência: reconhece a inter-relação quase inseparável desses fenômenos

B. Repetição semântica

i. Repetição sinonímica: sinonímia linguística ou situacional

ii. Repetição por superposição de sentido: unidades linguísticas com sentido próximo mas não igual.

a. mesma denotação, diferente conotação: linguística e situacional 
b. diferente denotação, mesma conotação

c. diferente denotação e diferente conotação.

iii. Repetição temática

iv. Mise en abyme: retomada de aspecto pertinente e contínuo do texto: um referente interno

C. Repetição morfossemântica: combina elemento formal e de conteúdo, sem que haja um dominante: repetição afixal

D. Convergência: as repetições se separam com dificuldade nos textos e a convergência é mais a regra que um caso especial, o que gera "redes repetitivas extremamente complexas" (Frédéric, $1985: 221)$

Do contraste entre a primeira tipologia, baseada na retórica, e a segunda, fruto da incorporação de noções da linguística, percebemos algumas diferenças marcantes. Primeiramente, vemos agora uma maior precisão nos critérios utilizados para categorizar o fenômeno. Apesar de a extensão sintagmática se confirmar como o fio organizador da primeira tipologia, foi possível notar a presença da semântica a cada nível da classificação retórica em formulações como: "com ou sem alteração de sentido", "com ou sem parentesco semântico". Na segunda tipologia, a semântica está concentrada apenas no item (B) dedicado a esse critério, que ganha maior detalhamento, e no item híbrido da morfossemântica (C). A compartimentação é, aliás, a tônica da nova classificação. Há mais níveis na tipologia linguística em geral - de seis níveis, passamos a catorze - , mas sobretudo mais subordinações — no lugar de um nível principal, mais um subnível 
para as repetições de sons e de palavras, o critério linguístico conta até quatro níveis de subordinação. Introduziu-se um nível superior que separa as repetições voluntárias das repetições espontâneas (marcado em algarismos romanos). As repetições deliberadas — único objeto da retórica — ganhou mais subníveis, por exemplo. O aumento do nível de detalhes pode-se explicar pela incorporação da nomenclatura linguística, que traz com ela toda uma série de nuanças de categorização: as repetições deixam de ser "de palavras" e passam a ser "lexicais", mas também são tipográficas, suprassegmentais, sinonímicas, morfossemânticas, para citar algumas.

Na passagem da primeira tipologia (retórica) para a segunda (linguística), Frédéric (1985 : 231-246) chega à definição da repetição (espontânea ou elaborada) na linguagem como um fenômeno unitário, confirmando assim a afirmação de Barthes (1970 : 195) de que a escolha taxonômica implica um ponto de vista, ou seja, a escolha por se concentrar sobre um grupo preciso de figuras permitiu definir o fenômeno da repetição de maneira global. Na concepção da autora, a repetição como fato de linguagem consiste na reaparição — não imposta pela língua — de um elemento formal, de um conteúdo ou da combinação desses dois elementos num mesmo enunciado. A ressalva de que o retorno de um elemento não pode ser fruto de uma exigência da língua descarta redundâncias do tipo de uma correferência: "Ela 1 perdeu o seu chapéu". A autora trata assim da recorrência linguística como um fenômeno geral, que se divide em redundância e repetição. Esta é de livre escolha do locutor e percebida pelo interlocutor, enquanto aquela é exigida pela língua e não sentida pelo interlocutor. ${ }^{15}$

\footnotetext{
${ }^{15}$ Consideramos problemáticos os termos da divisão entre redundância e repetição,
} 
Podemos sintetizar as contribuições de Frédéric ao estudo do fenômeno da repetição na retórica em três pontos principais. Ao reunir os diferentes casos de repetição espalhados nos tratados de retórica, a autora trouxe uma unicidade ao fenômeno, que resultou na definição de repetição. Ao se desvencilhar da necessidade de que as repetições sejam deliberadas, ela pode aumentar o escopo do estudo, exemplificado pela ampliação da lista de figuras. Por fim, a incorporação de noções linguísticas reorganizou e especificou o inventário - agora com mais subníveis - e permitiu mesmo prever repetições não atestadas.

\subsection{Crítica à Perspectiva de um Inventário de For-}

\section{mas}

Ao final de seu segundo inventário de formas, Frédéric (1985:226) reconhece que "desligada de qualquer comentário estilístico, ela [a descrição da rede repetitiva do texto] parece um tanto gratuita e fastidiosa". ${ }^{16}$ Trata-se de constatação semelhante àquela de Barthes $(1970: 218)$ quando menciona o "furor de classificação, indiferente às chacotas que contudo logo surgiram". ${ }^{17}$ A reação um tanto derrisória dos pesquisadores, se compreensível,

uma vez que não se pode dizer das repetições involuntárias, que Frédéric insiste em adicionar ao seu inventário, que sejam de livre escolha do locutor. Discutiremos mais detalhadamente esse ponto abaixo ao tratar da incorporação da noção de enunciador, preferível a locutor; o que produz uma transferência da discussão de uma intenção a uma intencionalidade.

${ }^{16}$ Tradução nossa para: "coupée de tout commentaire stylistique, elle [la description du réseaux répétitif du texte] apparaît quelque peu gratuite et fastidieuse".

${ }^{17}$ Tradução nossa para: "rage de classement, indifférente aux railleries qui ont cependant très tôt surgi". 
informa-nos pouco sobre as limitações dessa perspectiva. Propomos assim uma crítica tanto ao procedimento geral de inventariar formas, quanto especificamente ao trabalho de Frédéric, o que permitirá, de um lado, justificar nossa escolha por um caminho diferente e, de outro, introduzir a abordagem semiótica.

\subsubsection{Forma vs. Conteúdo}

Uma primeira questão que pode problematizar os inventários de Frédéric é a da separação entre formal e semântico (ou de conteúdo - expressões empregadas como sinônimas pela autora). Apesar de não discutir diretamente o ponto, vemos que a autora se confronta com o problema ao modificar a organização do inventário, na passagem do retórico ao linguístico, de forma a excluir toda referência à semântica nos diferentes níveis e concentrá-la no grupo dedicado exclusivamente à repetição semântica e no grupo dirigido à repetição morfossemântica. Apesar da tentativa de separar mais nitidamente essas duas categorias no inventário linguístico, a autora não apresenta diretamente uma definição que distinga os dois conceitos.

A questão fica particularmente espinhosa no interior da categoria que compreende ambos os critérios: as repetições morfossemânticas. Segundo Frédéric (1985:218), essa categoria abriga repetições ao mesmo tempo formais e de conteúdo, sem que se possa decidir qual o "elemento dominante". Apesar de também não definir a noção de "dominância", intuímos do texto que ela se traduziria pelo "fator responsável", algo que pode ser compreendido por meio da questão: a repetição é fruto de um fator semântico ou 
formal? O problema dessa formulação está na valoração desigual de partes do discurso, sem justificativa para tanto. A repetição morfossemântica prevê unicamente: a repetição afixal, que pode ser repetição do mesmo afixo com o mesmo sentido (conotativo e/ou denotativo) ou do mesmo sentido por afixos diferentes. Para Frédéric (1985 : 220), ambos são exemplos do mesmo mecanismo: "há a cada vez repetição/reaparição de um mesmo conteúdo significado [...], realizada por meio de (um) elemento(s) de natureza afixal". ${ }^{18}$

A autora não aborda de maneira semelhante a repetição de raízes. Estas são apresentadas em meio às repetições formais, entre as fônicas e as lexicais (Frédéric, 1985:143-155). Apesar de considerada como formal, o caráter fronteiriço da retomada de raízes, que as aproximariam da natureza das repetições afixais, deixa-se ver não somente pelo fato de a autora tratá-la como uma "passagem progressiva" entre dois outros tipos de repetição, mas também por não serem os casos reconhecidos sequer numerados ou marcados como os demais. Em outras palavras, a repetição de raízes é descrita no interior das repetições formais, mas sem um lugar de direito, sem entrar na contagem geral das figuras de repetição: assim como para os afixos, a repetição de raízes é marginal. Há, ainda, mais semelhanças entre as raízes e os afixos. Por se tratar de parte de uma palavra, as raízes sofrem restrições e alterações de composição paralelas às dos afixos que a elas se unem. Os afixos variam segundo a raiz, como é o caso do prefixo francês "in-": "inapte", "inconciliable", "illettré", "irresponsable", "imprudent"

\footnotetext{
${ }^{18}$ Tradução nossa para: "il y a chaque fois répétition / réapparition d'un même contenu signifié [...], réalisée au travers d'un (d') élément(s) de nature affixale."
} 
(Frédéric, $1985: 221)$. Entretanto, as raízes se manifestam diferentemente também em função dos afixos. Tome-se como exemplo as consoantes finais não pronunciadas em francês, que se fazem presente no feminino, no infinitivo e em palavras derivadas: "constant" vs. "constante"; "permet" vs. "permettre"; "permis" vs. "permission".

Ora, se a autora havia analisado as repetições de raízes como formais, por que tratar os afixos diferentemente, fundando uma categoria unitária exclusiva para tratar desse caso? Essa hesitação da autora, que a faz separar duas categorias não claramente distintas — raízes e afixos — e inchar o seu sistema a fim de acomodar um único caso de difícil categorização, é fruto da dificuldade de tratar o sentido. ${ }^{19}$ Vimos acima que o critério semântico é definido negativamente, por uma limitação do critério formal (de extensão sintagmática). Por outro lado, se o critério formal encontra seu limite na impossibilidade de abarcar certas repetições, o critério semântico é ubíquo e englobante, ainda que pouco definido.

\subsubsection{Forma vs. Substância}

É em grande medida pela dificuldade de abordagem de critérios semânticos que se explica a preferência por uma classificação baseada na extensão sintagmática. Os comentários de Frédéric (1985:63) sobre a classificação a partir dos critério de causas e efeitos da repetição também refletem essa

\footnotetext{
${ }^{19}$ Usamos o termo geral "sentido" justamente para espelhar a imprecisão da autora, que vai usar termos como "semântico" e "de conteúdo" como sinônimos, conforme mencionado anteriormente. A separação desses termos virá quando introduzirmos a perspectiva semiótica. Note-se que a oposição forma vs. conteúdo que abre esta seção será substituída por forma vs. substância na próxima, revelando o direcionamento pretendido.
} 
dificuldade. Segundo a autora, o critério das causas é mais frágil que o dos efeitos pois uma causa pode dar origem a diferentes tipos de repetição, ao mesmo tempo que um único tipo de repetição pode ser fruto de diferentes causas. Seu argumento não nos parece muito válido porque algo semelhante poderia ser dito dos efeitos: como atestar o efeito produzido sem cair em interpretações individuais? A interpretação é também um inventário potencialmente aberto. O que talvez esteja na raiz de suas questões é a oposição entre produção e recepção, em que as causas para uma repetição têm a ver com as condições de produção de um texto e os efeitos com a leitura do texto. Haveria assim uma ideia de que a produção é mais distante, é uma suposição de intenção muito difícil de reproduzir unicamente a partir do texto sob análise. ${ }^{20}$ Entretanto, a recepção gera problemas semelhantes, uma vez que as condições de leitura podem variar no tempo e conforme a proficiência, o conhecimento de mundo e da literatura que tem o leitor.

A questão parece tão pertinente quanto antiga. A semiótica propõe uma abordagem que busca suspender a hesitação entre esses dois polos, no sentido de que produção e recepção são absorvidos pelo texto e só temos de um ou do outro os vestígios propostos pelo texto. Em outros termos, a produção e a recepção são tratados como simulacros criados pelo texto e correspondem a dois lados de uma mesma instância pressuposta: a enunciação (Greimas \& Courtés, 2011 : 171). Nesse contexto, causa pode ser entendida como aquilo que no texto leva a uma certa repetição; efeito é o caminho de leitura que o texto nos propõe reforçado pelo que se segue à

\footnotetext{
${ }^{20}$ Uma certa teoria literária vai procurar elementos fora do texto, como dados da vida do autor e do momento de escrita do texto, conjunturas sócio-históricas, etc. para melhor fundamentar elementos da produção.
} 
repetição, não necessariamente de um ponto de vista linear, mas apenas lógico. $^{21}$

Independentemente dessa saída imanentista e sintagmática, efeitos e causas seguem sendo critérios difíceis de serem exauridos e mesmo a autora abandona esses critérios na tipologia linguística. A própria formulação de Frédéric, citada acima, de que a forma está a serviço do sentido implica, de um lado, sentidos múltiplos para uma forma e, de outro, formas múltiplas para um sentido. Em outras palavras, o polo semântico constitui uma categoria aberta e assim impõe dificuldades a sua apreensão pela linguística: "A semântica lexical, em sua maior parte, como a fonética, estão ausentes da análise paradigmática, porque as séries de seus lexemas são abertas" (Badir, $2014: 172) .{ }^{22}$ Assim, podemos entender a escolha de Frédéric, uma vez que parece contraintuitivo, ou possivelmente contraproducente, usar de critérios semânticos para um inventário que se quer abrangente e idealmente completo.

Um caminho para o tratamento dessa questão seria um estudo mais aprofundado das paixões. E é justamente desse tipo de efeito que tratam os retóricos: indignação, cólera, admiração (Frédéric, 1985: 63). Sobretudo, é preciso procurar traços semânticos mais gerais que abarquem o campo de forma mais global e evite, assim, a tarefa infindável de descrever inventários abertos. A proposta que desenvolveremos amiúde nos capítulos que se seguem passa por aí: buscamos a repetição como criadora de expectativas

\footnotetext{
${ }^{21} \mathrm{~A}$ linearidade tem um largo papel a desempenhar na organização da repetição nos textos, mas isso será discutido no Capítulo 3.

${ }^{22}$ Tradução nossa para: "La sémantique lexicale, pour sa majeure partie, comme la phonétique, sont absentes de l'analyse paradigmatique, car les séries de leurs lexèmes sont ouvertes."
} 
e organizadora do fluxo textual. Assim, entramos no terreno do sentido por sua forma, e não por sua substância (a semântica). Nesses termos, a repetição pode levar a causas e efeitos que se configurem nessas paixões, mas não acreditamos que se possa dizer que seja responsável por esta ou aquela paixão, a não ser em casos particulares ou contingentes, o que tornaria a teorização improvável.

\subsubsection{Imanência vs. Transcendência}

Conforme apontamos, os estudos de Frédéric, além de abordar o conteúdo por meio de sua substância - e não da forma, como propomos -, não distingue de forma clara o que é imanente ou transcendente no texto. Já mencionamos as dificuldades de determinação de causas e efeitos quando em relação com o extralinguístico. Na discussão acerca da delimitação do fenômeno da repetição, Frédéric (1985: 86) distingue repetição de redundância, por ser aquela perceptível para o interlocutor e esta não. Mesmo o critério primeiro de separação dos tipos de repetição é baseado numa escolha do locutor: repetições podem ser involuntárias, inconscientes, lexicalizadas ou deliberadas. Logo, a repetição para a autora possui relação com a subjetividade do interlocutor (suas escolhas) e do locutor (sua intenção). Ora, se a saída da semiótica para a noção de produção e percepção passa pela incorporação de seus atores no texto, também essa é a estratégia aqui:

Para explicar a comunicação enquanto ato, introduz-se geralmente o conceito de intenção, que se supõe motivá-la e justificá-la. Essa noção 
nos parece criticável, na medida em que a comunicação é então encarada, ao mesmo tempo, como um ato voluntário - o que certamente ela nem sempre é - e como um ato consciente - o que depende de uma concepção psicológica, demasiadamente simplista, do homem. É por isso que preferimos o conceito de intencionalidade [...] ele permite conceber o ato como uma tensão que se inscreve entre dois modos de existência: a virtualidade e a realização. (Greimas \& Courtés, $2011: 267)$

Com essa mudança de paradigma, Greimas \& Courtés abandonam o conceito de intenção em favor de uma instância imanente. Ao falar de tensão entre virtualidade e realidade, os autores estão novamente fazendo referência ao simulacro da produção do texto que transforma as estruturas semióticas possíveis em uma enunciação realizada. Mais uma vez, não estamos falando aqui do ato em si, mas das estruturas virtuais que se revelam no enunciado e que apontam para essa passagem de uma virtualidade a um fato realizado. No caso proposto por Frédéric, é menos relevante que o interlocutor perceba ou não a ocorrência da repetição, pois isso é contingente, que a facultatividade da repetição em relação às estruturas virtuais da língua. É a obrigatoriedade ou facultatividade do mecanismo que abre espaço, por exemplo, para a manipulação discursiva ou para a criação de ritmos e expectativas. A inclusão de uma ideia de intenção do locutor ou uma percepção concreta do interlocutor adicionam problemas de psicologia e percepção que estão além do escopo dos estudos linguísticos. Tanto é verdade que esses conceitos são apresentados de chofre por Frédéric, como fazendo parte de um "senso comum" da linguística, sem 
definição precisa.

Um outro momento em que as fronteiras do texto estão borradas é no tratamento das repetições suprassegmentais (Frédéric, 1985 :164-178). A autora baseia a sua análise de repetições de intensidade e altura, por exemplo, em casos de leitura dos poemas escritos. Generalizar acerca do texto escrito a partir de uma ou duas leituras é problemático. Para que esse tipo de análise ganhasse legitimidade, seria preciso uma amostra muito maior, com certos cuidados para obter-se uma larga gama que compreendesse o máximo de variantes possíveis.

Entretanto, o que vemos como questão mais importante por suas consequências teóricas é a mudança de nível de pertinência na delimitação do objeto. Até essa altura do livro, tratava-se do texto escrito. Ao considerar a leitura, saímos do plano do texto escrito para considerar pelo menos o texto oral. Ora, se vamos considerá-lo dessa perspectiva, observações acerca da tipografia ou das homografias se tornam irrelevantes. Por outro lado, o que nos impede de passar ao nível da perfórmance e tratar das contribuições da gestualidade e do público, ainda que subentendido à noção de uma perfórmance? Em resumo, é preciso definir bem o seu objeto de análise e, se resolvemos mudar de perspectiva, devemos minimamente reconhecer a mudança e justificá-la. Se não, abrimos nossas possibilidades para um infinito de gradações que pode começar no signo e acabar em formas de vida (Fontanille, 2006). Essa indefinição torna impossível até mesmo chamar essas diferentes gradações de níveis, pois não sabemos onde começa um e acaba o outro, além de tornar também indefiníveis os limites do imanente e do transcendente, com as consequências que discutimos acima. 


\subsubsection{Indução, Contingência e Abertura}

Para introduzir o inventário das repetições deliberadas, Frédéric (1985: 128) anuncia alguns dos casos que serão abordados, terminando a sua lista da seguinte maneira: "as diversas modalidades de repetições levantadas pela retórica clássica e aquelas que puderam sê-lo, para a época atual, nas páginas seguintes." ${ }^{23}$ Essa observação denuncia uma certa contingência da lista. Ainda assim, resta um desejo de totalidade aliado à consciência de sua impossibilidade: “o inventário que se segue gostaria de ser, mas sem pretender sê-lo de forma alguma, o mais completo possível." (Frédéric, 1985 : 129) $)^{24}$ Para responder a esse inacabamento, a autora propõe, além do esforço no sentido de abarcar o maior número de casos possíveis, encarar seu inventário como uma categorização aberta à incorporação de novas espécies de repetição. A flexibilidade da lista se deixa ver na gradativa passagem entre os níveis, por exemplo, na transição gradual da repetição fonossemântica à repetição lexical pura, mas também nos casos de convergência de diferentes repetições (Frédéric, 1985 : 230).

No entanto, a resposta da linguista é pouco mais elaborada do que sua afirmação anterior de um inventário "o mais completo possível". Isso porque, quando se parte de casos particulares atestados e vai-se em busca de uma síntese mais geral ou menos limitada do que as instâncias de partida, há sempre a possibilidade de surgimento de casos ainda não atestados e que não podem ser categorizados nas sínteses já criadas. É por isso que o

\footnotetext{
${ }^{23}$ Tradução nossa para: “les diverses modalités de répétitions relevées par la rhétorique classique et celles qui ont pu l'être, pour l'époque actuelle, dans les pages suivantes"

${ }^{24}$ Tradução nossa para: "l'inventaire qui suit se voudrait, mais ne se prétend nullement être, le plus complet possible."
} 
final de estudos como esse é sempre contingente e nunca generalizável.

O procedimento que vai do componente à classe é por definição o método indutivo. Segundo Louis Hjelmslev (2003 : 13-14): “Este [o método indutivo] conduz inevitavelmente à extração de conceitos hipostasiados como sendo reais. [...] os conceitos assim obtidos não têm valor geral e só se aplicam a um determinado estágio de uma dada língua." Note-se que, assim como para a língua, os conceitos obtidos por Frédéric são válidos até a "época atual".

Por conta disso, a classificação da linguista encontra seus limites ainda dentro do universo sob escrutínio. Casos como o da resposta em eco, ecolalia, retomada e pleonasmo esclarecedor ficam excluídos do inventário por tocarem elementos de "diversas naturezas", ou seja, por dizerem respeito a diferentes níveis de análise (Frédéric, 1985 :230). Além disso, cria-se uma categoria de um único componente para acomodar um caso excepcional que escapa às sínteses até ali estabelecidas. Esse é o caso da categoria "morfossemântica", cujo único componente é a repetição afixal discutida acima.

Assim, chegamos à conclusão, com Hjelmslev (2003: 14), que “a indução, neste campo [na linguística], não leva das flutuações à constância, mas apenas das flutuações ao acidental. Em última análise, o método indutivo entra em conflito com o princípio do empirismo". Este exige que a descrição seja "não contraditória, exaustiva e tão simples quanto possível" (Hjelmslev, 2003:11). Ora, vimos que o sistema de Frédéric não consegue ser nem exaustivo, uma vez que deixa de fora alguns casos de repetição atestados, nem simples, porque se vê obrigado a criar categorias para acomodar casos 
singulares.

A saída proposta por Hjelmslev (2003 : 14) é a do método dedutivo:

Se se pretende partir dos dados supostos da experiência, é exatamente o processo inverso que se impõe. [...] esses dados são, para o linguista, o texto em sua totalidade absoluta e não analisada. $\mathrm{O}$ único procedimento possível para isolar o sistema que esse texto subentende é uma análise que considera o texto como uma classe analisável em componentes; estes componentes são, por sua vez, considerados como classes analisáveis em componentes, e assim por diante até a exaustão das possibilidades de análise. ${ }^{25}$

A história desta tese é a busca dessa perspectiva hjelmsleviana no tratamento da repetição.

\subsubsection{A Recusa do Sentido}

Em meio aos comentários acerca do inventário de formas (linguístico e retórico), retomamos aqui uma questão que permeia todas as demais: o tratamento do sentido. Vimos uma recusa de um critério semântico para a classificação das formas, suplantado pelo critério da extensão e da posição sintagmáticas. No entanto, o sentido se via sempre presente intermeando o critério sintagmático e chegamos mesmo a apontar de que maneira todo o estudo retórico gira em função do sentido a ser manipulado.

No polo linguístico, há um cuidado maior da autora em excluir a semântica do componente classificatório, relegando-a a dois casos apenas

\footnotetext{
${ }^{25}$ A concepção de texto como uma "totalidade absoluta e não analisada" não é simples e merece maior desenvolvimento. Ver Capítulo 2 abaixo.
} 
(repetição semântica e morfossemântica). Ainda assim, o sentido está profundamente imbricado mesmo na classificação mais "formal" de Frédéric, haja vista que o primeiro elemento divisor das figuras diz respeito à possibilidade de efeitos: de um lado, repetições involuntárias, inconscientes ou lexicalizadas; de outro, repetições deliberadas ou "com efeitos possíveis". Ademais, o critério semântico, apesar de restrito a suas partes específicas no inventário, ganha muito mais níveis e detalhamentos.

No entanto, encontram-se também aí muitas inconsistências. A sua razão primeira para estender o inventário retórico com base na linguística é que o inventário inicial só abarca repetições "com efeitos possíveis". Assim, incluem-se casos de repetições involuntárias e inconscientes. O incongruente aqui é que anteriormente, no Capítulo 1 da segunda parte, a linguista havia anunciado que estavam excluídas de seu inventário as repetições que são fruto de uma exigência gramatical da língua, como a correferência, pois essas não são sentidas como tal pelo interlocutor e portanto não são passíveis de gerar efeitos. Então, ela abre o inventário para repetições que vão além daquelas com efeitos possíveis, mas exclui as repetições por exigência gramatical só porque não podem gerar efeitos?

De fato, a autora reconhece efeitos potenciais nas repetições inconscientes. Elas podem ser um entrave à comunicação ou "pesar" sobre o discurso, gerando monotonia ou desatenção (Frédéric, 1985 : 126). A repetição deliberada, por sua vez, pode ser fruto de uma tentativa de esclarecimento, pode servir para marcar um acordo com o interlocutor, para facilitar a compreensão, provocar uma irritação, criar um efeito de solenidade, pode desacelerar o conteúdo e colocar a conclusão em evidência, criar um efeito 
cômico (Frédéric, 1985 : 127-128). Mais uma vez parece estar em jogo um desequilíbrio entre produção e recepção. Se há a possibilidade de um efeito sobre o interlocutor, então a repetição merece um lugar no esquema: é o caso das repetições involuntárias e inconscientes, além das repetições deliberadas. No entanto, se a repetição é "involuntária"26 e não percebida pelo interlocutor, ela não encontra seu lugar no inventário: esse é o caso da correferência. Voltamos assim aos problemas que a assunção de uma percepção extralinguística pode trazer, como discutido acima.

De todo modo, o principal é que, se mencionados, os aspectos semânticos não são jamais desenvolvidos. Ainda assim, seu caráter extenso e totalizante faz com que eles reapareçam insistentemente no texto, como uma espécie de denegação que só torna mais presente o termo que se busca refutar. Vemos que os efeitos elencados por Frédéric são por demais particulares a certa percepção do texto, exceto talvez o comentário sobre a desaceleração gerada pela repetição. $\mathrm{O}$ andamento é uma categoria mais geral, mas principalmente ele trata mais da organização do texto do que de uma reação potencial. Ao levar em consideração o andamento, abre-se a perspectiva de interpretar a repetição como um desencadeador de uma certa leitura, um elemento organizador.

Outra questão espinhosa ligada à semântica é a dos efeitos gerados pelas figuras, que se manifestam potencialmente como paixões. Sem uma definição clara de como se constroem esses efeitos e do que entender por

\footnotetext{
${ }^{26}$ Adicionamos aspas a "involuntárias" porque esse é um critério emprestado de Frédéric e que não encontra seu lugar nos estudos semióticos, seja pela vontade do locutor estar colocada em xeque pela noção de intencionalidade, seja porque uma outra forma de dizer, uma reformulação que evite uma certa construção, é sempre concebível.
} 
"paixão", essas noções ficam por demais abertas: as paixões podem ser tantas quantas nuanças de sentimentos pudemos imaginar.

Sendo assim, como abordar esse sentido denegado e, por isso mesmo, tão presente? Vimos algumas pistas à medida que discutimos cada ponto deste capítulo: a criação de um simulacro de enunciação e da busca por traços mais gerais, não figurativos, mas figurais (como o do andamento sugerido no próprio texto de Frédéric), a delimitação de determinada imanência ou transcendência. São essas perspectivas que apontam para uma abordagem do conteúdo pela forma e não pela substância. Assim, evitamos a categoria aberta da semântica, em favor da categoria potencialmente esgotável da forma do conteúdo. Dissemos que essas concepções mais generalizantes da repetição são o nosso propósito final. Antes porém de abordar diretamente a repetição, é preciso entender de que maneira a retórica foi recebida e incorporada nos estudos semióticos, e assim preparar a mudança de perspectiva que vamos propor nos capítulos que seguem.

\subsection{Semiotização e Retorização}

Fiorin (2014: 18) reconhece duas formas de aproximação entre a linguística e a retórica:

uma é a que considera que há uma retoricidade geral, que é a condição mesma da existência da produção discursiva; outra, que vê a retórica como um instrumento ainda válido de análise discursiva e que busca repensar a retórica antiga à luz das modernas descobertas da ciência da linguagem. 
Podemos afirmar com certo grau de confiança que a perspectiva de Madeleine Frédéric corresponde à segunda abordagem, uma vez que a autora propõe uma atualização segundo a linguística, mas ainda partindo do formato proposto pela retórica. Frédéric busca essencialmente entender o fenômeno da repetição pela sua extensão. Fiorin, por sua vez, adota o primeiro ponto de vista e enxerga a retórica como um princípio organizador do discurso: uma "retoricidade".

Uma das consequências da concepção de retórica adotada pelo semioticista é justamente o abandono da ideia de intenção do orador em favor de uma intencionalidade do enunciador, em que a escolha deliberada não entra em questão. A retórica deixa de ser prescritiva e passa a ser entendida como competência.

Isso significa que não se almeja mais construir uma retórica, entendida como estratégia consciente visando a produzir determinados efeitos no auditório, mas busca-se analisar a retoricidade de toda operação de linguagem." (Fiorin, 2014:16).

O mesmo tipo de ampliação de escopo dos fatos da retórica é realizado por Georges Molinié (1994: 102-103) ao tratar de uma "estruturação figurada". O pesquisador reúne tropo e figura sob a denominação de ornamento, mas defende que o ornamento é "consubstancial ao regime retórico do discurso". Do ponto de vista de uma pragmática da sedução, o discurso é sempre ornado, ainda que pela ausência de ornamento numa "estética do despojamento".

Assim, por trás das diversas listas de figuras de retórica, antigas e modernas, alguns teóricos encontraram certas generalizações e certas direções 
que serviram de porta de entrada para uma abordagem da retórica pelas teorias do discurso contemporâneas. Denis Bertrand (2009:163) descreve as figuras em termos de deslocamentos e intensificações a ponto de "'colocar literalmente sob os olhos' por meio de um dispositivo figurativo apropriado uma significação de outra forma inacessível". ${ }^{27}$ Para Molinié (1994 : 103), a ênfase é a qualidade ideal do discurso e as figuras surgem como uma atividade discursiva particular. Claude Zilberberg (2006a:43) também reconhece um traço de intensificação e de ênfase no centro da retórica tropológica. Para este último, porém, esse caráter da retórica extrapola o particular e funda a base das operações elementares da semiótica tensiva:

Essas operações perfeitamente elementares, que permitem aos termos de se oporem a si mesmos no fio de um contínuo orientado, são a aumentação e a diminuição. Ora, a metade da retórica tropológica, essa que é "útil" a todos, gravita em torno da intensificação, da ênfase, de uma busca pela repercussão. ${ }^{28}$

Nesse sentido, o ponto de vista tensivo é antes uma "retorização da semiótica" que prepara uma "semiotização ulterior da retórica" (Zilberberg, 2006a:44).

Outra questão ligada a esse novo ponto de vista sobre a retórica é apresentada por Bertrand:

a retórica repousa sobre um "vazio", uma ausência no discurso: seja

\footnotetext{
${ }^{27}$ Tradução nossa para: "'mettre littéralement sous les yeux' par le biais d'un dispositif figuratif approprié une signification autrement inaccessible".

${ }^{28}$ Tradução nossa para: "Ces opérations tout élémentaires, qui permettent à des termes de s'opposer à eux-mêmes au fil d'un continuum orienté, sont l'augmentation et la diminution. Or la moité de la rhétorique tropologique, celle qui est 'utile' à tout un chacun, gravite au tour de l'intensification, de l'emphase, d'une quête du retentissement."
} 
pela parte faltante do raciocínio no entimema, pelo indizível do sentido revelado e ocupado pela catacrese ou pela metáfora, pelo jogo de deslocamento de posições enunciativas na ironia, pela implantação de uma posição de fala no lugar de uma ausência na prosopopeia... ${ }^{29}$ (Bertrand, 2006:68)

Esse vazio é, para o semioticista, criador de uma tensão que a atividade discursiva tende a preencher. Uma abordagem tensiva dessa configuração discursiva procura resolver o espaço criado entre as significações concorrentes pela análise do modo de existência das grandezas semânticas: virtual, atual, real ou potencial. ${ }^{30}$

Uma maneira - talvez mais básica — de apresentar esse espaço discursivo é de tratá-lo como "a ausência, a inadequação profunda das palavras às coisas e à infinitude do real, a impropriedade fundadora do sentido que deve se desdobrar para valorizar a presença" (Bertrand, 2009 : 165-166). ${ }^{31}$ Essa questão se faz presente na retórica pelas noções de sentido próprio e sentido figurado. A distância e o laço entre próprio e figurado serão tratados pela semiótica tensiva não como uma questão de substituição, mas como uma interseção de categorias semânticas das grandezas em “tensão competitiva ou conflitual".

\footnotetext{
${ }^{29}$ Tradução nossa para: “la rhétorique repose sur un 'creux', une absence en discours: qu'il s'agisse de la part manquante du raisonnement dans l'enthymème, de l'indicible du sens révélé et occupé par la catachrèse ou la métaphore, du jeux de déplacement des positions énonciatives dans l'ironie, de l'implantation d'une position de parole à la place d'une absence dans prosopopée..."

${ }^{30}$ Bertrand menciona também o grau de assunção das instâncias enunciativas. Não vamos discutir instâncias enunciativas nesta tese.

${ }^{31}$ Tradução nossa para: "l'absence, l'inadéquation foncière des mots aux choses et à l'infinitude du réel, l'impropriété fondatrice du sens qui doit se dédoubler pour faire valoir de la présence."
} 
Tanto o problema da ênfase quanto o da impropriedade do sentido serão incorporadas como questão de base para a semiótica tensiva, que vai buscar na estrutura prosódica as categorias do acento e da modulação para dar um tratamento linguístico a esse aspecto do conteúdo (Zilberberg, 2000). Vemos assim esboçados nessas propostas os dois lados da formulação de Zilberberg: tanto as questões trazidas pela retórica para a semiótica, como um tratamento semiótico dado a essas questões.

Elegemos, como Frédéric, a repetição como centro de nossas reflexões. Entretanto, diferentemente dessa autora, nossa ênfase não está "no que se repete". Essa pergunta leva à criação de inventários e tipologias. Fiorin (2014:10), por sua vez, propõe já uma perspectiva semiótica, procurando inserir as figuras num contexto mais amplo como mecanismos de construção do discurso, como operações enunciativas de intensificação (e atenuação) dos significados a serviço do fazer persuasivo. Com isso, afasta-se da noção de uma lista de formas com exemplos, apesar de organizá-las de maneira seriada e apresentar as figuras de repetição como um subgrupo.

Nosso propósito é ainda outro. Encaramos a repetição como macrofigura que marca um certo regime figural. Buscamos na verdade as condições textuais de sua emergência tentando encontrar pistas para o entendimento da construção de ênfases e esperas no texto. Afinal, como afirmou Zilberberg, a intensificação e a ênfase estão no centro da retórica tropológica e as esperas e as surpresas são regidas pela modulação desse regime. 
Este capítulo é o da reunião. Ele procura - com certo espírito globalizante dos manuais de retórica - abarcar o campo relevante para um estudo discursivo da repetição. A retomada da retórica neste capítulo cumpre um papel introdutório de duas frentes. Ao proceder a uma crítica da perspectiva de inventários, pudemos esclarecer os limites do procedimento indutivo e, com isso, advogar pelo método dedutivo que norteará este estudo como um todo, mas que estará em evidência nos Capítulos 2 e 3. Por outro lado, a breve discussão acerca da incorporação das noções de impropriedade do sentido e da criação de ênfase pela semiótica formam as bases para as discussões sobre ritmo, espera e surpresa que impelem os Capítulos 4 e 5.

Se até aqui reunimos, passamos agora a dividir. Passamos a escolher o que é mais pertinente à nossa perspectiva. Passamos a analisar. 
2

\section{O Lugar da Repetição na}

\section{Semiótica Hjelmsleviana}

Lack one lacks both, and the unseen is proved by the seen, Till that becomes unseen and receives proof in its turn. 
No capítulo anterior, tratamos da repetição na retórica e numa certa linguística, que são disciplinas vizinhas à semiótica e com a qual compartilham algumas perspectivas e objetos. Porém, de um ponto de vista semiótico, ou seja, de uma teoria da significação, o fenômeno da repetição parece ainda vastíssimo. Se dermos um passo atrás e nos dirigirmos ao mundo com olhos mais ingênuos de quem procura fazer sentido das coisas, constatamos que a repetição está em toda parte: nos azulejos do meu banheiro enquanto escovo os dentes; nas linhas do caderno em que rabisco ideias, no ruído das teclas do computador que transcrevem frases um pouco mais ordenadas. Mesmo se considerarmos apenas o componente verbal, repetimos sons isolados, sílabas, palavras, frases, mas também sentidos. Parafraseamos o tempo todo. Repetimos uma mesma estrutura sintática e mudamos as palavras. Se o universo do que sentimos como repetição é tão vasto a ponto de ir além da reiteração sonora ou lexical, se percebemos também recorrências de sentidos e de estruturas sintáticas, a repetição em si parece então ser portadora de todo e qualquer tipo de semelhança. Nesse sentido, a própria organização sintagmática e paradigmática de um sistema semiótico está implicada nesse mecanismo, uma vez que ele parece ser fundado nas identidades que se somam ao lado das diferenças. Sendo assim tão largo o fenômeno, onde recortar esse objeto? Onde parar? Ou melhor, por onde começar?

Frédéric (1985:237-238) indaga sobre essa questão do nível de pertinência: a repetição enquanto um fato da linguagem está ancorada no nível da língua ou do discurso? Para a autora, a repetição pertence ao nível do discurso já que se define como a "reaparição no interior de um enunciado". 
Sua conclusão nos parece pouco esclarecedora, uma vez que não estabelece claramente a definição e a distinção de enunciado e discurso. Que indícios tem Frédéric de que a repetição está no enunciado? Por um lado, a repetição parece ter que estar presente na superfície textual. Entretanto, a própria autora levanta casos de repetições de sentido que encontram sua manifestação por meio de diferentes elementos de expressão. Por outro lado, menciona casos em que são usados dados da língua, de paradigmas (como a homonímia e polissemia), mas que ainda exigem a reaparição no sintagma para serem compreendidos propriamente como repetições. Parece haver aí relações de níveis (sintagma vs. paradigma; língua vs. discurso vs. enunciado) que merecem ser mais profundamente investigadas.

Para tanto, propomos uma longa pausa na discussão direta acerca da repetição a fim de revisitar a definição de semiótica para Hjelmslev, bem como seus componentes. A partir daí, retomaremos a discussão sobre a repetição pelo viés da identidade. Essa trajetória nos permitirá decidir com mais propriedade em que nível da semiose se encontra a repetição. Essa constituirá a nossa primeira delimitação do fenômeno. Passemos então aos objetos hjelmslevianos.

\subsection{Semiótica}

Nos quadros da glossemática de Louis Hjelmslev, não vamos opor língua e discurso, mas língua e texto. Texto é uma sintagmática de uma semiótica denotativa (Hjelmslev, 2010 : Def. 39). O sentido dessa definição ficará mais claro no desenrolar desta discussão, mas o que importa notar é que 
o entendimento da noção de texto depende de uma definição do que é semiótica. O mesmo pode ser dito da língua, que é uma paradigmática de uma semiótica denotativa (Hjelmslev, 2010 : Def. 38). Para desenvolver e esclarecer essa definições, retomaremos brevemente os comentários e a interpretação da teoria hjelmsleviana proferidos por Sémir Badir (2014 : 81189) em seu livro Épistémologie sémiotique.

A semiótica é, antes de mais nada, uma análise. Mais do que uma observação corriqueira de que a análise está na base do nosso conhecimento dos objetos semióticos, essa afirmação é uma tomada de posição epistemológica. A análise não é apenas um meio de abordar o objeto, mas é aquilo que o funda como tal. ${ }^{1}$ Ela pode ser sintagmática ou paradigmática, a depender da função em pauta. Hjelmslev postula uma exigência de uniformidade das dependências: se uma análise sintagmática se inicia, essa será a função de toda a derivação. Essa mesma exclusividade se mantém no caso da análise paradigmática.

No entanto, a semiótica não é apenas uma análise simples (Classe $=$ componente $1+$ componente 2 ), mas uma análise contínua, ou seja, os componentes da primeira análise são novamente submetidos à análise e assim sucessivamente.

\footnotetext{
${ }^{1}$ Mais será dito acerca do caráter "fundador" da análise na discussão sobre a concepção de texto abaixo.
} 


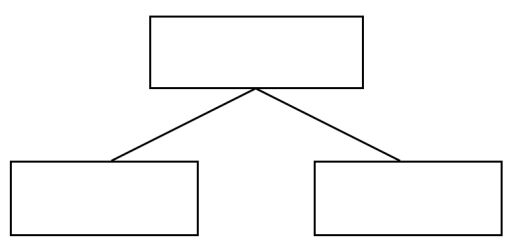

(a) Análise simples

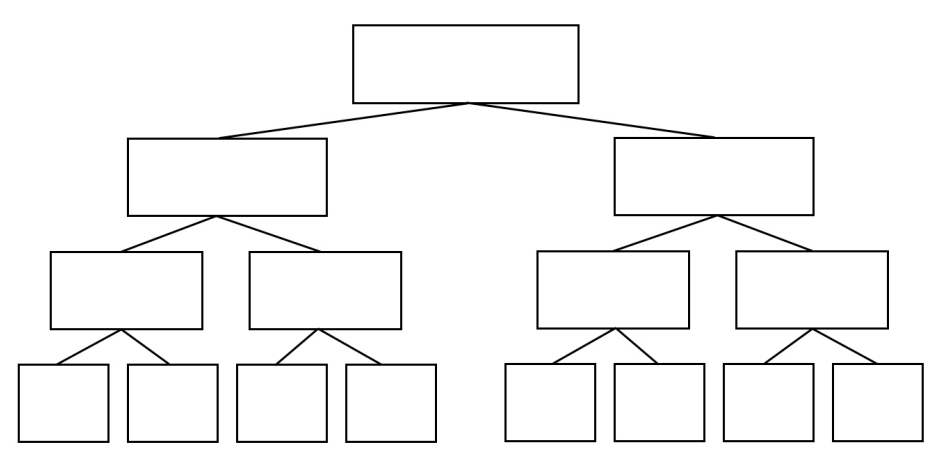

(b) Análise contínua

Figura 2.1 - Representações de análises

A relevância de se apontar que as duas funções não podem se misturar decorre diretamente do fato de que nao se trata apenas de uma divisão, mas de uma série de divisões sucessivas. A exigência de uniformidade determina a natureza de todas as etapas da análise.

A análise é a apreensão de um objeto pela dependência que outros objetos (componentes) estabelecem em relação a esse primeiro (que, pela análise, se torna classe). ${ }^{2}$ Em outras palavras, ao visar um objeto a ser des-

\footnotetext{
${ }^{2}$ As classes são, a rigor, o próprio objeto da análise. Objetos esses que são, em seguida,
} 
crito, obtém-se um novo objeto. Esse objeto pode novamente ser submetido à análise e gerar novos objetos e assim sucessivamente até os elementos mínimos, limite em que uma análise não mais seja possível (Hjelmslev, 2003 : 11; 103-107). Na sequência da descrição do primeiro objeto, todas as novas dependências que se estabelecem entre os objetos descritos em níveis mais baixos devem guardar uma homogeneidade em relação à primeira descrição, ou seja, devem preservar a mesma função de partida. Ao preservar a homogeneidade, a análise gera uma sintagmática ou uma paradigmática.

Graças a essa relação "descendente", em que a descrição de um objeto gera novos objetos, que serão, por sua vez, submetidos a novas análises e assim sucessivamente, a análise contínua constitui uma hierarquia e uma direção. A semiótica é assim uma análise, uma hierarquia e um "caminho" linear de dependências uniformes. ${ }^{3}$ Isso dá conta apenas do caráter "vertical" e dirigido da semiótica, que vai da substância à forma. Isto é, a cada etapa da análise, apura-se a forma que subjaz à substância. Os objetos granjeados por meio da análise são substâncias, potencialmente passíveis de uma nova análise que as transformará em forma de novas substâncias.

Esse caráter vertical, que diz respeito à descrição (ou recorte) do objeto e à constituição de uma hierarquia, não é suficiente para a definição de analisados em componentes. Ver Hjelmslev (2003:34-37 e 2010) para as definições de análise, classe e componente.

${ }^{3}$ As dependências são uniformes. Isto é, se os componentes $a$ e $b$ são fruto da análise de uma classe $X$, eles são dependentes apenas dessa classe. Eles não estabelecem uma dependência com uma classe $Y$. Um componente que dependesse de duas classes geraria não uma análise mas uma fragmentação. Para uma discussão do caráter uniforme da dependência, que é central para a definição de uma semiótica e, portanto, da língua, ver Badir (2014: 102-106). 
uma semiótica. A semiótica depende também da noção de mutação. A mutação se presta não a descrever um objeto, mas a especificar uma hierarquia, ou seja estabelecer uma conexão horizontal entre as funções que se estabeleceram na descrição dos objetos.

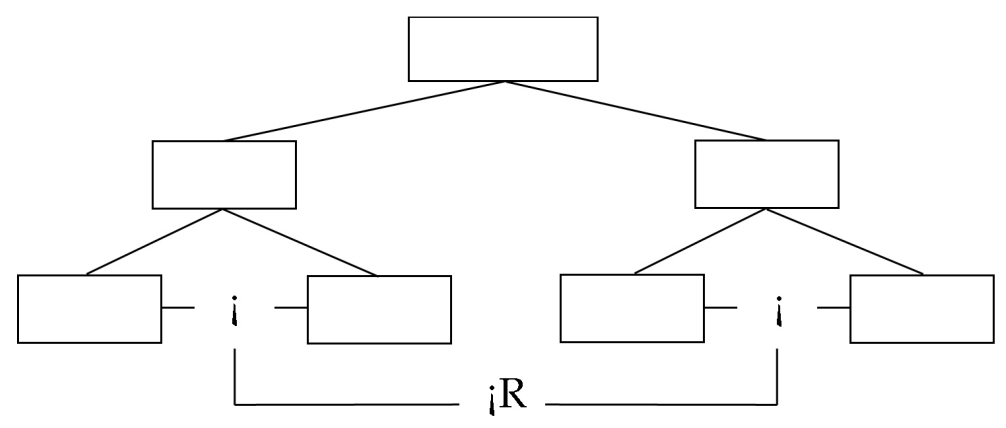

Figura 2.2 - Representação de uma mutação

A mutação é, então, essa função ( $\mathrm{i}$ ) entre derivados de uma mesma classe, mas que estabelece uma relação (R) com uma outra função ( $\mathrm{i}$ ) entre derivados de uma outra classe. ${ }^{4}$ No caso de uma derivação sintagmática, a mutação é chamada permutação, ou uma função entre as partes de uma cadeia (função e...e). Numa derivação paradigmática, é chamada comutação, ou uma função entre componentes de um paradigma (função ou... ou). A relevância desse mecanismo para a determinação de uma semiótica pode ser percebida num exemplo de comutação entre fonemas.

Dissemos que a dependência entre os objetos produzidos pela análise os organiza em classes. Na análise paradigmática, as classes serão os paradigmas. A prova da comutação torna a natureza ou a substância dos

\footnotetext{
${ }^{4}$ Note-se que os derivados, bem como as classes, devem estar no mesmo nível da derivação. Veja a figura 2.2 acima.
} 
traços que os reúnem irrelevante para a análise, uma vez que a comutação é uma análise "cega". Dito em outros termos, para a identificação de uma invariante, ${ }^{5}$ temos que a uma mudança no plano de expressão (uma classe) corresponde uma alteração no plano do conteúdo (outra classe), mas os traços físicos ou articulatórios que são modificados e os traços de sentido que variam não são relevantes para entender que esses elementos são invariantes e, portanto, participam de uma classe. O que importa é tão somente o fato de que a variação num plano gera variação no outro de forma regular. Tomemos um exemplo de identificação de fonemas. A troca de $p$ e $b$ em "pato" e "bato" gera uma mudança de conteúdo de 'pato' para 'bato'. ${ }^{6}$ No entanto, a alteração dos mesmos elementos de expressão em "pala" e "bala" produz igualmente uma mudança no conteúdo, mas são conteúdos distintos do primeiro par. Se, na primeira troca entre $p$ e $b$, passamos do "nome comum de uma ave aquática" (pato) para "a primeira pessoa do singular do presente do verbo bater" (bato), na segunda troca dos mesmos $p$ e $b$, o conteúdo passa de "uma peça de vestuário com calda" (pala) para "um projétil de arma de fogo" (bala). Assim, a diferença de conteúdo entre 'pato' e 'bato' não é análoga à diferença entre 'pala' e 'bala'. O que é constante é a relação entre essas correlações, ou seja, a uma troca entre $p$ e $b$ corresponde também uma troca no conteúdo. É esse fato que garante que $p$ e $b$ integram o paradigma dos fonemas do português brasileiro e não, por exemplo, o fato de que houve uma alteração de sonoridade.

\footnotetext{
63).

${ }^{5}$ Invariante é o resultado de uma análise por comutação (Hjelmslev, 2003:139 — Def.

${ }^{6}$ Utilizamos a mesma convenção de Badir (2014): expressão, 'conteúdo' e "manifestação".
} 
Aliás, a sonoridade em português do Brasil pode aparecer em questões de neutralização, como a pronúncia da fricativa em coda nas palavras casca e rasga. No primeiro caso, o s é pronunciado " $\mathrm{s}$ " e no segundo, " $\mathrm{z}$ ", em função da sonoridade da consoante seguinte. Uma vez que não é o traço em si, mas a possibilidade da comutação que determina os fonemas, os elementos $s$ e $z$ não deixam de integrar o paradigma dos fonemas da língua. Trata-se aí apenas de um caso de neutralização ou sincretismo. $\mathrm{Na}$ verdade, é porque $s$ e $z$ fazem parte de uma mesma classe que podem entrar num sincretismo, uma vez que um sincretismo é justamente fruto de uma mutação suspensa (Hjelmslev, 2003 :93-97) — neste caso, uma comutação suspensa.

A prova de comutação na teoria hjelmsleviana não é grandemente diferente da forma como é compreendida na linguística de fundo estruturalista em geral. O que interessa para esta discussão é, primeiramente, que a comutação encontra um correlato na sintagmática, que é a permutação. Essa característica torna a mutação generalizável para as duas funções da língua (paradigmática e sintagmática). Outro fator importante é que, por ser uma relação "cega", garante-se a imanência da teoria, sem recorrer à substância ou à matéria. Nos termos de Hjelmslev (2003: 103):

O procedimento é puramente formal, no sentido em que considera as unidades da língua como compostas por um certo número de figuras às quais se aplicam certas regras precisas de transformação. Estas regras são estabelecidas sem considerar a substância na qual as figuras e as unidades se manifestam.

Por fim, contrariamente à derivação hierárquica, a mutação tem como 
característica a ausência de direção pois ela é sempre mútua. Trata-se de uma relação entre componentes da expressão e componentes do conteúdo e vice-versa. A mutação estabelece uma proporção: $a$ está para $b$ como $a^{\prime}$ está para $b^{\prime}$, onde $a$ e $b$ são elementos, por exemplo, da expressão e $a^{\prime}$ e $b^{\prime}$, do conteúdo. O aspecto mútuo da mutação faz com que essa ordem não seja importante contanto que a proporção esteja garantida. A consequência essencial dessa última característica é que, ao se estabelecer entre os derivados dos dois primeiros componentes da análise (expressão e conteúdo), que se encontram no mesmo plano hierárquico, a mutação confere à semiótica seu caráter horizontal.

Assim sendo, para a definição de uma semiótica, é preciso que haja a descrição de um objeto na forma de uma hierarquia de dependências uniformes (caráter vertical), mas também que se estabeleçam entre os objetos da derivação uma proporção na forma de uma mutação mútua (caráter horizontal). As dependências são responsáveis por uma progressão e uma direção da derivação, não apenas na medida em que revela as formas subjacentes às substâncias, mas também por engendrar, a partir de uma substância a descrever, todos os objetos frutos da análise do objeto visado. A progressão e a direção conferem um caráter dinâmico e tensivo à derivação. Por outro lado, a mutação traz a proporção e garante a estrutura, uma vez que cabe a ela fazer da expressão e do conteúdo uma relação, isto é, perfeitamente formal.

Resta ainda uma questão a abordar para encerrar a definição de semió- 
tica. Dissemos que a análise pode ser sintagmática ou paradigmática, mas que deve ser homogênea, o que significa que não pode ser ao mesmo tempo uma e outra, nem ora uma, ora outra. Sendo assim, como dar conta do fato de que ambas as funções fazem parte da derivação de uma semiótica? Como será possível combiná-las, se a combinação é interditada pela exigência da homogeneidade? Ainda seguindo a argumentação de Badir (2014: 121 e ss.), a resposta reside na formulação "análise ulterior" que faz parte da definição de semiótica. ${ }^{7}$ Segundo o semioticista belga, essa análise ulterior não diz respeito à continuação de uma mesma análise no interior de uma única hierarquia:

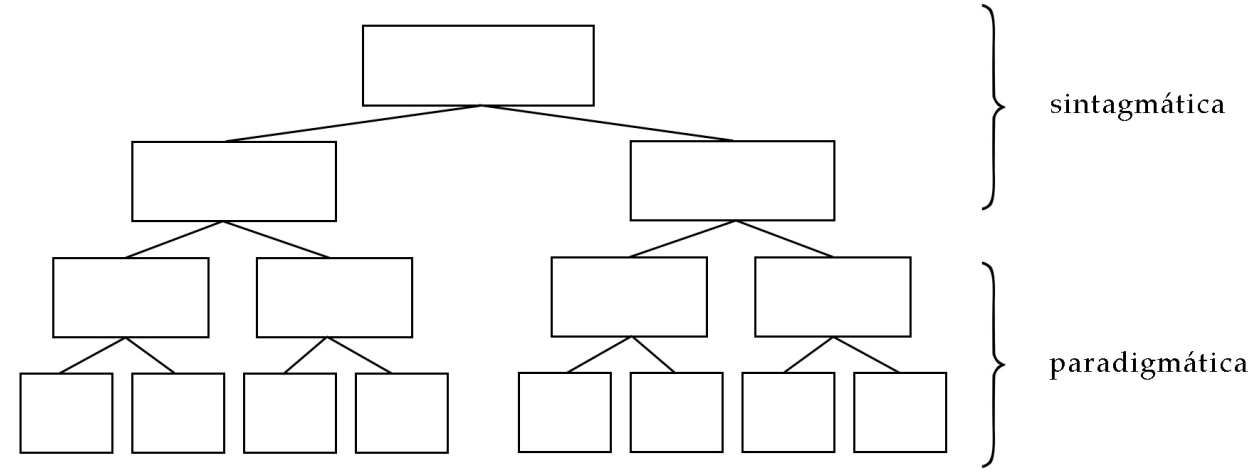

Figura 2.3 - Representação de uma análise não-homogênea

Trata-se aí de uma análise contínua contendo duas funções distintas. $\mathrm{O}$

\footnotetext{
7“Uma semiótica (símbolo: $\gamma^{0} g^{0}$ ) é uma hierarquia em que cada um dos componentes admite uma análise ulterior em classes definidas por relação mútua, de tal maneira que cada uma dessas classes admite uma análise em derivados definidos por mutação mútua." (Hjelmslev, 2010 : Def. 24) (Tradução nossa para: “Une sémiotique (symbole: $\gamma^{o} g^{o}$ ) est une hiérarchie dont chacune des composantes admet une analyse ultérieure en classes définies par relation mutuelle, de telle sorte que chacune de ces classes admette une analyse en dérivés définis par mutation mutuelle." - grifos nossos).
} 
início de uma derivação sintagmática que continua como paradigmática seria uma análise não homogênea, ferindo os princípios estabelecidos por Hjelmslev. O caráter ulterior pode, ao contrário, ser interpretado como uma nova hierarquia, distinta da primeira. Temos, enfim, uma nova hierarquia paradigmática, que é logicamente posterior à sintagmática, e não a continuação desta (Hjelmslev, 2003 : 106-107).

Não fica claro então como dar conta dessa junção entre a sintagmática e a paradigmática. A seguinte passagem dos Prolegômenos a uma Teoria da Linguagem nos dá a dica:

O fator particular que caracteriza a dependência entre a totalidade e as partes, que a diferencia de uma dependência entre a totalidade e outras totalidades e que faz com que os objetos descobertos (as partes) possam ser considerados como interiores e não exteriores à totalidade (isto é, o texto) parece ser a homogeneidade da dependência. (Hjelmslev, $2003: 33)$.

Esse trecho parece estar falando mais uma vez da necessidade da homogeneidade já tratada acima, mas ele introduz algo importante. Se a homogeneidade da dependência é o que garante que estamos tratando de partes e totalidades, podemos então concluir que essa exigência não se mantém para a relação entre totalidades. Passamos então a entender o encontro da paradigmática com a sintagmática como a reunião de duas totalidades. Precisamos apenas encontrar o mecanismo que permita associar totalidades.

Para tanto, podemos lançar mão do conceito de complexo de análises. Este define-se como uma classe de análises, ou seja, uma classe que reúne duas 
(ou mais) análises que podem ser distintas entre si, ainda que homogêneas em suas derivações individuais. Cada análise no interior do complexo permite uma única dependência entre seus componentes: uma hierarquia de relações (um processo) ou uma hierarquia de correlações (um sistema). O próprio complexo, porém, comporta uma e outra hierarquia.

Uma semiótica é, nesses termos, um complexo de análises, sendo o processo semiótico a sintagmática, e o sistema semiótico a paradigmática. Dessa maneira, é possível coordenar esses dois níveis e dar conta do fato de que a análise do texto e a análise da língua (a sintagmática e a paradigmática, respectivamente) visam ambas o mesmo objeto. Esse objeto visado pelas duas análises é também chamado texto. Assim, na teoria hjelmsleviana, texto é tanto o objeto a ser descrito como o resultado da análise sintagmática, o que explica o caráter ambíguo dessa noção.

Completamos enfim os aspectos que definem a semiótica. Nos termos de Badir (2014: 125), semiótica é uma hierarquia cujos planos mantêm relação mútua em função das proporções estabelecidas entre seus derivados. Mas é também o complexo de duas análises contínuas — sintagmática e paradigmática - ambas partindo da primeira divisão em dois planos: expressão e conteúdo. A fim de ilustrar essas relações e sem prejuízo do caráter sequencial que há entre sintagmática e paradigmática, Badir (2014 : 130) propõe a seguinte representação operacional: 


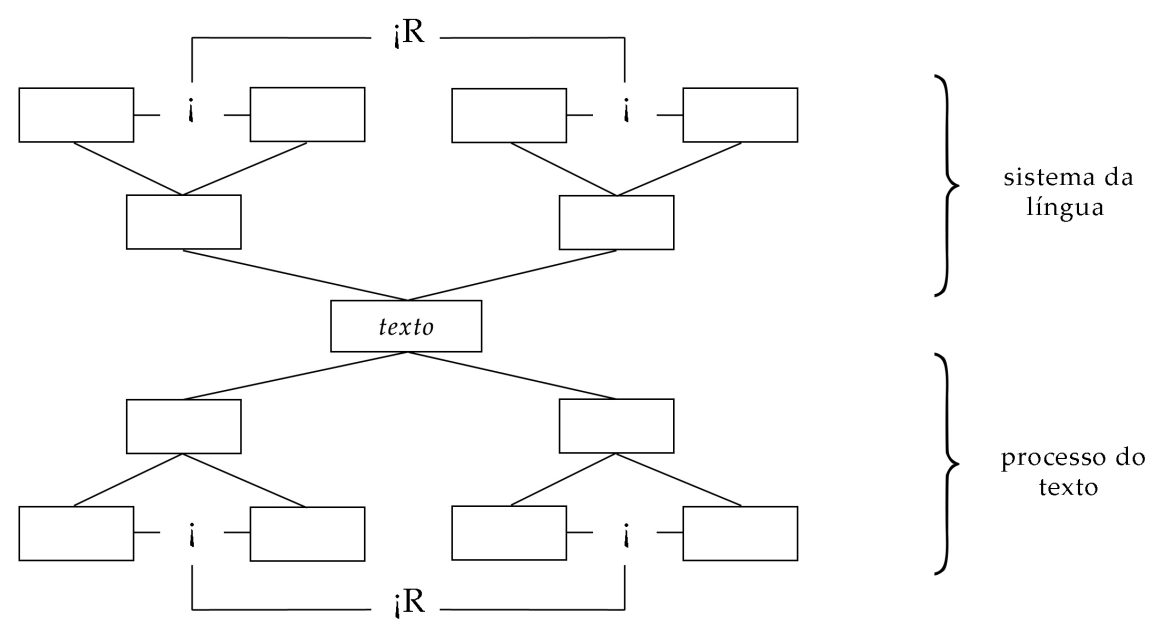

Figura 2.4 - Representação operacional de uma semiótica

\subsubsection{Definição de Texto}

A definição de semiótica nos levou a pelo menos duas noções de texto: o objeto inicial da análise e a resultante da análise sintagmática. Precisamos abarcar a totalidade dessas acepções e ainda dar conta da noção de texto aceita pelo senso comum (Badir, 2012): algo como $o$ texto enquanto domínio e os textos enquanto empiria. Não podemos a priori separar o texto dos próprios meios de seu conhecimento: o estudo do texto se dá por meio de textos. Somos assim mergulhados num jogo de espelhos metalinguísticos que nos coloca, em última instância, diante de uma totalidade absoluta, cujos constituintes podem ser manifestados para qualquer propósito, por qualquer matéria e com qualquer sentido (Badir, 2014 :153). Esse texto ideal é passível de manifestar não apenas qualquer desses elementos, mas todos eles. Em outros termos, estamos tratando aqui de propósitos, matérias 
e sentidos antes de podermos distingui-los como tais. A possibilidade de manifestação de todos os sentidos também determina uma extensão indefinida.

\section{Universal, geral, particular}

A extensão indefinida e a expressão infinita conferem a esse objeto um caráter universal. Numa formulação um tanto circular, a definição de uma operação universal é que ela se aplica a todo e qualquer objeto. Se a universalidade atribui um lugar epistemológico para o texto, ela não diz muito da possibilidade de especificação. Note-se que, por outro lado, o texto pode ser ainda generalizado: "Se um objeto admite univocamente uma solução, e se um outro objeto admite equivocamente a mesma solução, neste caso a solução é generalizada e aplicada ao objeto equívoco." (Hjelmslev, 2003 : 72). Esse princípio de generalização não trata mais de uma universalidade abrangente e não delimitada. Propõe-se agora o reconhecimento de objetos que, dadas determinadas circunstâncias, podem passar pela mesma operação. Esse é o caso do texto generalizado: nessa acepção, texto é qualquer objeto que pode passar por uma derivação sintagmática. Assim, além de um elemento totalizante e absolutamente indefinido (o texto como universalidade), é também a reunião de todos os textos particulares, reais ou potenciais. Por fim, para que seja um texto, ou seja, um objeto particular, é preciso que se possa descrevê-lo como tendo esta ou aquela característica específica (Badir, 2014:153). Não se pode examinar um objeto dotado de todas as características possíveis.

Em outras palavras, antes da primeira análise, é impossível dizer o que 
quer que seja de um elemento empírico qualquer. A ideia de que um dado real seja uma sequência de constituintes que faz sentido, ou ainda, de que se trata de um texto, não passa de suposição. Mas mesmo essa suposição parte de um lugar teórico no qual cadeias de constituintes que fazem sentido são possíveis. Assim, ao postular esse texto universal (Hjelmslev, 2003: 14), Hjelmslev cria um lugar epistemológico que torna possível a consideração e a análise de objetos que se confirmem como textos (pois só saberemos se são mesmo textos após a análise), ao mesmo tempo em que os constitui como objetos de conhecimento.

Essa concepção epistemológica do texto gera dois movimentos inversos. Por um lado, aumenta o campo da teoria da linguagem para além da língua, pois tratamos aqui de objetos semióticos e não apenas linguísticos. Por outro, permite a restrição do campo de estudo ao separar o que é necessário do que é acessório: separa-se a forma da substância (Badir, 2014: 155).

O processo de especificação do texto universal segue este caminho: a apreensão desse objeto universal e, por enquanto, homogêneo ${ }^{8}$ se dá por meio da análise, uma vez que a análise, enquanto operação universal, é adequada a todo e qualquer objeto (Badir, 2014 : 157). Se lograr, passamos a entender esse texto universal em termos de um objeto geral: ele se torna a classe que subsume os textos particulares. Uma outra consequência do sucesso da análise é que esse objeto passa a estar em relação com os demais objetos particulares, por meio das relações de dependência homogênea que discutimos acima. Colocado de outra maneira, ao instaurar os objetos

\footnotetext{
${ }^{8}$ A rigor, não podemos dizer, antes da análise sobre a sua estrutura interna. Por isso mesmo, o texto enquanto domínio se apresenta sem distinções, sem partes.
} 
particulares, de que o texto é a classe, ele se torna um objeto geral. A análise dota esse objeto de alteridade, heterogeneidade e "contabilidade": ele se multiplica em instâncias individuais que se deixam contar (Badir, 2014:157-158).

Vemos assim uma mudança de estatuto desse texto universal. De indeterminado, ele passa a objeto de conhecimento, na medida em que é o objeto (geral) determinante dos textos particulares. Ao mesmo tempo, o texto geral se distingue de seus constituintes justamente porque os determina (Badir, 2014:163). O texto deixou assim de ser apenas uma totalidade absoluta e não analisada, para adquirir essas configurações e não tem um papel único, mas abarca três instâncias interdependentes: o universal, o geral e o particular.

\section{Forma, substância e matéria}

A análise realiza uma operação de triagem. Por um lado, divide-se em constituintes. Por outro, realiza-se a redução a uma de suas partes, visto que se separa a forma do resto não analisado (Badir, 2012:17). O texto apreendido pela análise deixa, assim, de ser matéria, quer dizer, o sentido antes de qualquer determinação, ${ }^{9}$ e passa a ser designado por Hjelmslev (2003 : 53-64) como substância. Assim, a cada etapa da análise, obtém-se uma forma, que se revela justamente nos constituintes apreendidos, e um "resto". Esse resto, uma vez definido por relação à forma apreendida, será a substância.

\footnotetext{
${ }^{9}$ Para uma discussão sobre a noção de mening, ora traduzido por sentido, ora por matéria, ver Badir (2014: 150-153).
} 
Os constituintes são, então, o produto de uma divisão, de uma delimitação, de uma qualificação. Eles são o resultado propriamente dito da análise. A substância configura-se novamente num texto, sempre passível de ser submetido a uma nova análise. Sempre divisível, delimitável, qualificável, a substância está sempre no domínio do possível (Badir, 2014 :163-164).

O texto enquanto matéria é inapreensível senão pela reflexão epistemológica. A ele se opõem todos os textos enquanto substância. Assim, a análise retira do texto-matéria uma forma e um resto, sua substância. É esse resto, essa substância, a única empiria possível. O texto empírico bruto não é plausível dentro do sistema imanente hjelmsleviano. Apenas um texto submetido à análise pode atestar sua empiricidade.

Uma vez sob análise, o texto passa a ser a cadeia de seus constituintes. Os constituintes resultantes da análise são de dois tipos, sempre discretos e repetidos: derivados e encadeamentos de derivados. A partir deles, a análise continuada vai sempre na direção de uma maior discretização dos derivados e de uma categorização a cada vez mais geral dos encadeamentos.

Entretanto, para que se diga que um encadeamento de constituintes é um texto, é preciso que essa cadeia seja semiótica. ${ }^{10}$ Como vimos acima, para que seja semiótica, uma hierarquia deve também ser submetida a uma análise por mutação - o que, por si só, pressupõe uma análise em dois planos. A análise sintagmática divide então o texto em seus menores elementos permutáveis, que passarão em seguida pela análise paradigmática.

\footnotetext{
${ }^{10}$ Lembramos que o texto é definido por Hjelmslev (2010 : Def. 39) como uma sintagmática de uma semiótica denotativa.
} 
Esta os reunirá em categorias e subcategorias.

Assim, a análise sintagmática apenas recorta o texto em unidades menores, mas que guardam as mesmas características de sua unidade superior. Em outras palavras, as unidades menores continuam a ser cadeias. A análise sintagmática faz de um texto um novo texto. A análise paradigmática, por outro lado, opera categorizações. Delas obtém-se o sistema, ou seja, a língua. Assim, língua e texto configuram-se como os resultados de uma análise.

Para que um encadeamento de constituintes seja um texto, é preciso que ele tenha um sentido, minimamente que ele se deixe reconhecer como um objeto discreto, um constituinte. Submete-se então o texto a uma análise sintagmática. $O$ texto, feito objeto, se torna $u m$ texto, de modo que aquele texto absoluto e indeterminado de partida, transforma-se em cada constituinte na cadeia ${ }^{11} \mathrm{e}$, portanto, uma pluralidade de objetos. Visto que a cadeia tem propriedades de constituinte - discreta, repetida e comparável —, o texto torna-se uma variedade. O texto plural e variado revela-se assim heterogêneo (Badir, 2012:20-21).

Dessa forma, o texto hjelmsleviano é o objeto epistemológico, absoluto e indeterminado, que viabiliza a priori a apreensão de um objeto para a análise. É também a classe que subsume todos os demais textos possíveis (perspectiva paradigmática), além de constituir cada cadeia e todas elas, da totalidade separada em dois planos ao menor elemento permutável (perspectiva sintagmática).

\footnotetext{
${ }^{11}$ Cada constituinte na cadeia é um texto: um livro é um texto; um capítulo desse mesmo livro é também um texto; o mesmo pode ser dito de um parágrafo, uma frase e assim sucessivamente até os menores elementos permutáveis.
} 


\subsection{Identidade}

Uma vez definidos texto e língua na semiótica, resta-nos decidir qual o nível de pertinência do fenômeno repetitivo. Partimos de uma investigação em torno da dependência, ${ }^{12}$ em especial na análise paradigmática. Essa discussão nos levará a considerar a identidade e a identificação e, em seguida, à configuração da repetição na cadeia. Estamos fazendo o caminho inverso ao proposto no capítulo "Grandezas da Análise" dos Prolegômenos a uma Teoria da Linguagem (Hjelmslev, 2003: 103-107), no qual parte-se da análise sintagmática, que recorta a cadeia em seus elementos mínimos, e em seguida faz-se a dedução paradigmática, a fim de obter as unidades possíveis da língua. A repetição, entretanto, não é nem objeto nem função, elementos básicos a serem construídos pela análise. Ela é, neste momento de nossa investigação, tão somente a possibilidade de identidade ou similitude.

\subsubsection{Semelhança}

Segundo Hjelmslev (2003 : 79):

Nas línguas, semelhanças e diferenças pertencem àquilo que, com Saussure, denominamos de forma, e não à substância que é formada. [... ] O sentido é, em si mesmo, inacessível ao conhecimento, uma vez que a condição de todo conhecimento é uma análise, seja qual for sua natureza.

\footnotetext{
${ }^{12} \mathrm{~A}$ dependência é um indefinível na teoria hjelmsleviana, que pressupomos aqui (Hjelmslev, 2003 :34). Uma vez que estamos inseridos nesse quadro teórico, não é nosso objetivo buscar defini-la, mas apenas investigar alguns conceitos que lhe são tributários. Ela é aqui o centro em torno do qual gira a discussão.
} 
Se justamente começarmos pelo nível mais simples e abstrato e nos pusermos a investigar a estrutura linguística, descobriremos que uma certa recorrência é condição para a sustentação da arquitetura da língua. Mas o que é essa semelhança de que trata Hjelmslev no trecho citado? Se tomarmos a categoria dos fonemas da língua como exemplo, o que garante a semelhança entre seus integrantes? Não é possível que seja a matéria sonora que supostamente representam. Se assim fosse, a semelhança não estaria no domínio da forma, mas na substância. Para responder a essa questão, precisamos passar primeiro pela noção de dependência.

À formulação saussuriana de que na língua só há diferenças, Hjelmslev (2003 : 27 e ss.) acrescenta a noção de dependência. A dependência é, como discutido acima, o que determina os objetos, ou seja, é o relacionamento interno entre as partes de uma totalidade e a classe imediatamente superior, que funda essas mesmas partes. Num exercício hipotético em que nos desvencilhássemos da exigência de uma dependência entre as partes, poderíamos potencialmente decidir por uma divisão arbitrária de um objeto.

Segundo o realismo ingênuo, a análise provavelmente deveria reduzirse à decupagem de um dado objeto em partes, portanto em novos objetos, a seguir divididos em novos objetos, e assim por diante. Mas, mesmo neste caso, o realismo ingênuo teria de escolher entre várias decupagens possíveis. (Hjelmslev, 2003 : 28)

Os elementos que obteríamos dessa divisão aleatória, simplesmente pelo fato de não estarem em relação de dependência entre si - ou melhor, de estarem numa dependência não-homogênea entre si (Hjelmslev, 
2010 : Def. IV; Badir, 2014 : 102-106), não se reconfigurariam num todo. Não reencontraríamos uma conexão entre esses novos objetos e não poderíamos reencaixá-los e formar novamente o objeto de partida. ${ }^{13}$ Assim, é antes a dependência que determina as partes, que recorta a substância:

uma totalidade não se compõe de objetos, mas sim de dependências, e [...] não é a sua substância mas sim os relacionamentos internos e externos que têm uma existência científica. (Hjelmslev, 2003 : 28)

Nesses termos, a diferença de que falava Saussure está subordinada à dependência. Em outras palavras, a dependência que existe entre os elementos da língua nos permite enxergar que se tratam de instâncias distintas. Se há dependência entre os objetos isso significa que esses não são idênticos, mas estão necessariamente em relação mútua. Assim, se a análise logrou, é porque foi possível descrever um objeto em sua dependência uniforme de outros objetos distintos. Por outro lado, a dependência cria também um termo comum. Se os elementos estão em relação de dependência é porque há algo que os reúne na mesma categoria e os torna até certo ponto semelhantes. Voltamos à questão da semelhança, mas insistimos que a natureza desses traços é menos importante que a análise que os colocou em evidência. A chave para entender o porquê está na mutação que discutimos acima. Como exemplificamos por meio da prova da comutação entre $p$ e $b$ em português, a materialidade dos traços torna-se indiferente para a

\footnotetext{
${ }^{13}$ Essa reconfiguração de um todo é a descrição de um procedimento indutivo, i.e. de sínteses. Apesar de não ser por si só um procedimento suficiente par satisfazer as exigências da exaustividade e não produzir novos resultados, ele pode "fornecer um ângulo novo que às vezes será útil adotar para os mesmos resultados" (Hjelmslev, 2003 : 3536). É nesse sentido que fazemos apelo a esse cenário indutivo em nossa argumentação.
} 
distinção dos componentes: o traço de sonoridade que distingue os dois fonemas aqui não é pertinente em outros contextos. Isso revela que é a relação estrutural entre as partes analisadas que estabelece seu valor. $\mathrm{O}$ caráter "cego" e estritamente proporcional da prova da comutação elimina o fator material e coloca a dependência em primeiro plano.

A dependência é um elemento indefinível na teoria hjelmsleviana, mas ela é parte essencial da definição de análise, que, por sua vez, gera as classes e seus componentes. A identidade seria, nesse quadro de análise paradigmática, menos uma questão de semelhança substancial de traços do que a participação dos membros num mesmo paradigma. A bem dizer, em função da comutação e de seu caráter "puramente formal", a questão da semelhança substancial se torna irrelevante para o estudo das formas. Semelhança e identidade são assim a participação numa classe. Pela definição negativa (com base na prova de comutação), estabelece-se o valor e a posição relativa dos elementos no sistema. Na linha de Louis Hjelmslev, essa concepção de identidade nos liberta da contingência dos objetos materiais e a insere na economia geral da estrutura semiótica.

Aliás, libertar-se da materialidade dos objetos é uma exigência do estatuto epistemológico que Hjelmslev empresta à sua teoria da linguagem. A teoria não pode ser determinada pelos dados da experiência, uma vez que isso levantaria a questão da determinação desses dados. Essa determinação passaria, nesse caso, a ser extralinguística. No entanto, no quadro brevemente traçado acima, vemos que é antes a teoria que determina o objeto a partir da análise. $\mathrm{O}$ texto - dado empírico anterior a qualquer análise não é o objeto da linguística: "é de fato a partir deles [dos textos] que se 
constituem esses objetos [da linguística], mas sua especificidade só pode ser reconhecida uma vez realizada a análise." (Badir, $2000: 30) .{ }^{14}$ Assim, reencontramos a definição de texto discutida acima e reafirmamos, desta vez num contexto particular, a concepção de que a análise funda o objeto da linguística. O que nos leva à fórmula saussuriana do ponto de vista que cria o objeto. Hjelmslev cria, consequentemente, um estatuto epistemológico particular à linguística: ela não é como as ciências formais (por exemplo, a matemática), que não reconhecem um objeto empírico, mas também não se comporta como as demais ciências empíricas, cujos objetos são definidos por uma outra ciência (os objetos da biologia, por exemplo, são determinados pela química) (Badir, $2000: 34-35)$. Esse aspecto da epistemologia linguística faz com que ela seja ao mesmo tempo empírica e imanente.

\subsubsection{Identificação}

De volta à questão da identidade, o primeiro tomo do Dicionário de Semiótica (Greimas \& Courtés, 2011 : 251) afirma:

Por oposição à igualdade que caracteriza objetos que possuem as mesmas propriedades qualitativas, a identidade serve para designar o traço ou o conjunto de traços (em semiótica: semas ou femas) que dois ou mais objetos têm em comum. (grifos nossos).

Ainda não discutimos se a repetição é uma questão de igualdade ou de identidade, nos termos em que coloca o Dicionário. ${ }^{15} \mathrm{Na}$ verdade, no

\footnotetext{
${ }^{14}$ Tradução nossa para: “c'est bien à partir d'eux [des textes] que sont constitués ces objets [de la linguistique], mais leurs spécificité ne peut être reconnue qu'une fois l'analyse réalisée."

${ }^{15} \mathrm{Em}$ termos correntes, não parece haver muita distinção entre esses dois termos. Ambas
} 
início desta seção, abrimos para a possibilidade de considerar todos os tipos de aproximação como instâncias de repetição. Discutiremos quais são as repetições pertinentes nos capítulos a seguir. Para os propósitos desta discussão, abordaremos o cenário mais amplo possível: toda identidade, parcial ou total, será levada em conta. Em todo caso, na citação do Dicionário de Semiótica, ambos os casos tratam de uma identificação, total ou parcial, de dois ou mais objetos. Os traços (semas ou femas) mencionados no caso da identidade não são outra coisa senão as propriedades qualitativas referidas para a igualdade. A diferença entre uma e outra é, como dissemos, uma questão de grau, ou seja, da extensão da semelhança entre os objetos.

Entretanto, partimos de uma abordagem não material, mas tão somente formal. No sistema que estamos buscando montar, é preciso portanto encontrar uma saída também formal. No verbete "Identité" do segundo tomo do Sémiotique, Jacques Fontanille (1986:109-110) trata a identificação como operação sintagmática:

A identificação será uma operação, realizada por um observador, que consiste em reconhecer a coerência dos diversos papéis sucessivos incorporados por um mesmo ator, ou seja, em suma, em aspectualizar esse ator e em reintroduzir tensão e continuidade onde apenas havia

as definições no Trésor de la Langue Française informatisé (http:/ / www.cnrtl.fr/definition/) trazem referências a uma semelhança qualitativa. "Égalité" define-se, em uma de suas acepções, como "fato de não apresentar diferença de qualidade, de valor" ("fait de ne pas présenter de différence de qualité, de valeur"). Enquanto, para "identité", lê-se: "caráter de dois ou mais seres idênticos (identidade qualitativa, específica ou abstrata)" ("caractère de deux ou plusieurs êtres identiques (identité qualitative, spécifique ou abstraite)"). Em uma das acepções de "identité", há até mesmo referência a "égalité": "caráter daquilo que permanece idêntico ou igual a si mesmo no tempo (identidade pessoal)" ("caractère de ce qui demeure identique ou égal à soi-même dans le temps (identité personnelle)"). Assim mesmo, consideramos a divisão do Dicionário de Semiótica pertinente, ainda que não relevante a esta altura da discussão. 
descontinuidade sintáxica.

O fazer da identificação supõe um julgamento mínimo de adequação, que se aplica a pelo menos dois papéis, dois actantes ou dois atores. Se essas grandezas pertencem ao enunciado, trataremos de identificação enunciva; se pelo menos uma delas pertencer à enunciação, trataremos de identificação enunciativa. ${ }^{16}$

Nesse trecho, Fontanille fala de um procedimento de identificação. Não vamos entrar nos meandros da proposta e discutir observador, ator, aspecto, etc. Decantaremos, aqui, apenas aquilo que pode nos esclarecer o tratamento que queremos dar à identidade e à identificação e o seu lugar na teoria. Assim, a identificação está sendo tratada como uma operação na qual uma coerência é encontrada entre dois ou mais elementos diversos. $\mathrm{O}$ que o semioticista parece reconhecer, nos termos que vimos tratando até aqui, é a participação desses elementos numa mesma categoria. Em termos hjelmslevianos:

A fim de satisfazer a esta exigência [de que a análise conduza a elementos em menor número possível], deve-se dispor de um método que permita, em condições fixadas com exatidão, reduzir duas grandezas a uma única grandeza ou, como se diz mais frequentemente, que permita identificar uma com a outra. (Hjelmslev, 2003:66)

\footnotetext{
${ }^{16}$ Tradução nossa para: "L'identification sera une opération, assumée par un observateur, consistant à reconnaître la cohérence des divers rôles successifs assumés par un même acteur, c'est-à-dire, en somme, à aspectualiser cet acteur et à réintroduire de la tension et de la continuité là où il n'y avait que discontinuité syntaxique.

Le faire d'identification suppose au minimum un jugement d'adéquation, portant sur au moins deux rôles, deux actants ou deux acteurs. Si ces grandeurs appartiennent à l'énoncé, on parlera d'identification énoncive ; si au moins une d'entre elles appartient à l'énonciation, on parlera d'identification énonciative."
} 
Trata-se, ainda nesse caso, de uma relação entre classes e componentes. Lembremos suas definições. A classe é um objeto submetido à análise e os componentes são objetos registrados por uma única análise como sendo homogeneamente dependentes da classe e deles mesmos reciprocamente. Em poucas palavras, há entre a classe e seus componentes uma relação de dependência homogênea, o que é o mesmo que dizer: uma relação que preenche as condições da análise. Por outro lado, as grandezas, mencionadas na citação acima, são definidas como funtivos que não são funções. Se funtivos são os objetos, a função é a dependência que se estabelece entre esses objetos. Dessas definições decorre que grandezas podem ser tanto componentes como classes, uma vez que ambos são funtivos mas não funções. A relação apresentada no trecho acima, retirado dos Prolegômenos, apresenta duas grandezas que se identificam a uma só. Nesse contexto, o que essa citação afirma é que uma dependência se estabelece entre as grandezas identificadas e a grandeza hierarquicamente superior, que, por sua vez, subsume as duas grandezas atestadas. Dessa forma, podemos afirmar que há na identificação uma ocorrência particular da relação mais geral entre componente e classe. Em outros termos, faz parte da identificação o reconhecimento da participação de certos componentes em suas classes.

Um outro aspecto da identificação em jogo na definição de Fontanille é a sintagmática. O semioticista trata de "papéis sucessivos", "continuidade e descontinuidade sintáxica", "enunciação" e "enunciado". Assim, a identificação parece se dar no fluxo sintagmático. Esse mesmo aspecto se verifica na sequência da citação de Hjelmslev (2003: 66):

Seja um texto dividido em frases que são divididas em proposições, 
divididas estas, por sua vez, em palavras; se se levantar um inventário em cada divisão, sempre se poderá constatar que em várias partes do texto há a "mesma" frase, a "mesma" proposição, a "mesma" palavra: pode-se portanto dizer que cada frase, cada proposição e cada palavra surgem em vários exemplares. Diremos que são variantes de grandezas que são, estas, invariantes. [...] Em cada fase da análise devemos poder inferir das variantes para as invariantes por meio de um método especialmente concebido que fixe os critérios necessários para uma tal redução.

A questão da sintagmática está anunciada na referência às divisões do texto, mas o jogo entre processo e sistema só entra em questão quando também é mencionado o par variante e invariante. Os elementos obtidos a partir da análise sintagmática serão submetidos à prova de comutação. E serão, nos termos dessa segunda análise, variantes ou invariantes.

Para ser invariante, o elemento deve ser distintivo. Serão invariantes os correlatos que mantiverem a relação entre uma correlação do conteúdo e uma correlação da expressão, isto é, que atestarem a solidariedade entre a forma do conteúdo e a forma da expressão. Quando a relação não se mantiver, serão chamadas variantes (Hjelmslev, 2003 : 69). Segundo Hjelmslev, essas variantes são sempre passíveis à redução a invariantes num estágio subsequente da análise.

Pela definição de variante (Hjelmslev, 2010 :56), ela é também um componente de uma classe. Se há, descrito por Hjelmslev (2003:66), uma relação hierárquica em que as variantes são variantes de uma grandeza e que essa grandeza é uma invariante, então podemos afirmar que o procedi- 
mento de identificação é também uma instância da relação entre classe e componente (Badir, $2000: 71)$.

Se de variantes encontramos a invariante, estamos aqui tratando do sistema. A identidade que reconhecemos entre as variantes nos leva à classe. A identidade é portanto um fato da língua. A repetição, por outro lado, está no texto. Na citação de Hjelmslev (2003: 66), vimos descrito o procedimento sintagmático de decupagem e o reconhecimento da semelhança que há entre objetos encontrados em diferentes pontos da cadeia. Assim, o surgimento dos elementos repetitivos se dá na cadeia. Escolhemos então chamar identificação justamente a ligação entre as duas instâncias. Identificação é assim a operação que associa elementos semelhantes na cadeia participam de uma mesma classe no paradigma.

Chegamos a uma encruzilhada: nada podemos dizer neste momento acerca da natureza dessa operação de identificação a não ser que há evidências de sua presença e que é necessária à definição de repetição. O estudo da repetição nos faz ver que um liame se estabelece entre objetos derivados da sintagmática e aqueles obtidos na derivação paradigmática. Entretanto, no interior da teoria hjelmsleviana, tudo o que essas duas derivações partilham são os objetos. ${ }^{17}$ Sabemos também que a paradigmática é logicamente posterior à sintagmática e usa, portanto, dos objetos obtidos por esta última em sua derivação. Assim, a identificação será por princípio uma operação paradigmática de categorização dos elementos fornecidos pela sintagmática. Tomado por outro ângulo, podemos também dizer que as categorias

\footnotetext{
${ }^{17}$ Vimos na definição de semiótica acima que o texto é o objeto tanto da sintagmática quanto da paradigmática.
} 
da língua são necessárias para o estabelecimento da semelhança entre os elementos da cadeia. É preciso que se possa estabelecer esse laço entre as formas manifestadas e as categorias a que elas se reportam.

Assim, dissemos que o reconhecimento de dois elementos como variantes de uma mesma invariante é um caso particular da relação componente e classe. Vimos, porém, que a identidade entre dois elementos quaisquer, como dois fonemas da língua, também era uma questão de componente e classe. Reencontramos, nesses termos, a citação de Fontanille e com ela os dois casos de repetição concebíveis. Numa repetição parcial, temos de alguma forma essa relação hierárquica pois aquilo que há de comum entre os termos os fará invariantes de uma classe maior ou variantes de uma invariante. Entretanto, também o caso de identidade total está aí previsto, dado que toda ocorrência de um termo é potencialmente nova variante (Hjelmslev, 2003:86-87; Badir, 2000:70-71). Por trás disso, está a ideia de que cada ocorrência de um termo - por mais próxima — não repete perfeitamente a ocorrência anterior. ${ }^{18}$

\subsection{A Repetição na Semiótica Hjelmsleviana}

Iniciamos nossa discussão considerando as condições para que um objeto seja analisado como uma semiótica. Vimos que faziam-se necessárias as noções de dependência, que estabelece uma hierarquia dirigida, e de mutação, proporção entre os elementos de duas classes que garante o aspecto

\footnotetext{
${ }^{18}$ Esse tipo de variante recebe o nome de variedade na teoria glossemática (Hjelmslev, $2003: 85-87)$
} 
puramente formal da estrutura. Essa concepção mostrou-se central para a imanência da teoria semiótica, evitando que recorrêssemos à materialidade extralinguística. Usamos os próprios critérios que definem uma semiótica para tratar a repetição e, com isso, encontrar o seu lugar no sistema desenhado por Hjelmslev. Dessa forma, pudemos evitar as hesitações entre imanência e transcendência, forma e conteúdo, que tornavam oscilantes e por vezes imprecisas as definições levantadas no Capítulo 1.

Um outro aspecto da semiótica é o fato de se configurar num complexo de análises, nesse caso, duas análises que visam um mesmo objeto. De um lado, temos uma sintagmática que é o texto; de outro, uma paradigmática que é a língua. Com base nessa diferenciação e com apoio da análise formal, pudemos localizar a identidade na língua, uma vez que a identidade no sistema hjelmsleviano diz respeito à relação de componentes e suas classes. ${ }^{19}$ Vimos ainda que identificar dois elementos é reconhecer o pertencimento desses dois termos a uma mesma classe no sistema. Nesses termos, propusemos entender como identificação o mecanismo de passagem que reconhece na cadeia elementos de uma mesma classe no paradigma. Pelo fato de haver essa identificação e esse laço entre os elementos da cadeia e seus lugares no paradigma podemos dizer que uma instância é a repetição de outra. No entanto, a repetição em si se faz presente no texto.

Podemos concluir daí que as categorias da língua são condição para a repetição, uma vez que sem elas não seríamos capazes de reconhecer as semelhanças entre dois termos ou duas cadeias. Não fossem as categorias

\footnotetext{
${ }^{19}$ Ver também Badir (2014:118-119) para a relação entre a similaridade necessária ao estabelecimento do valor e a análise "descendente" fundada na dependência uniforme.
} 
da língua, cada nova cadeia de fala seria única e não guardaria relação com todas as outras produções vocais (ou qualquer que seja o meio de produção de intenção comunicativa). Em última instância, sequer poderíamos tratar essas produções por intermédio da fala, já que esta é uma manifestação da língua. Se não manifestar uma estrutura, não há fala, apenas ruído.

Por fim, vimos que o texto hjelmsleviano é ambíguo. Seguindo Badir, separamos três noções de texto: o texto epistemológico (texto universal, condição para a possibilidade de abordagem dos objetos semióticos); texto geral (categoria que subsume todos os textos reais e potenciais); e os textos particulares. Se adotamos essa definição múltipla de texto, devemos então localizar a repetição como pertencente à última instância. Se considerarmos que o reconhecimento de uma repetição implica que se isolem constituintes para que seja possível, em seguida, sua reunião numa mesma categoria, é preciso supor então que a repetição está na cadeia analisada.

Cremos, assim, ter encontrado a primeira delimitação do fenômeno que nos propusemos a estudar. Os paradigmas que garantem o reconhecimento da repetição estão na língua, porém a repetição em si está atestada no texto. 
3

\section{Condições Textuais para os}

\section{Efeitos da Repetição}

um conceito de repetição tal que as repetições físicas,

mecânicas ou nuas (repetição do Mesmo) encotrariam sua

razão nas estruturas mais profundas de uma repetição

oculta, em que disfarça e se disloca um "diferencial".

Gilles Deleuze 
No Capítulo 2, utilizamos os fundamentos da teoria para justificar o estabelecimento da repetição como um fenômeno do texto. Se esse movimento já cria uma delimitação para o fato, uma vez que lhe confere um lugar na teoria, permanece a questão de que a repetição constitui um fenômeno textual bastante heterogêneo. Isso pode ser visto, por exemplo, nas extensas listas compiladas por Frédéric e mencionadas na seção 1.2 acima. Em sua versão mais longa, víamos repetições involuntárias, inconscientes, deliberadas, tanto de sons como de palavras, sentidos, etc. Sendo assim, quais são as repetições pertinentes?

Ao abrir esta tese, mencionamos um caráter estruturador da repetição que, além de conferir certa coesão ao texto, regulava a espera e um determinado ritmo do conteúdo. Para melhor definir o que entendemos por "regulação da espera", tomemos como exemplo o poema "The Hollow Men" de T. S. Eliot (2004:86). Ele é repleto de repetições, mas a última estrofe é especialmente interessante.

This is the way the world ends

This is the way the world ends

This is the way the world ends

Not with a bang but a whimper. ${ }^{1}$

O primeiro verso da citação já traz toda a informação necessária para o entendimento do último. Em especial, o pronome demonstrativo "this" é responsável pela coesão dos termos da frase, uma vez que pede um referente no texto que só será apresentado no verso final (que revela de que

\footnotetext{
${ }^{1}$ Nossa tradução livre: “É assim que o mundo acaba / É assim que o mundo acaba / É assim que o mundo acaba / Não com uma explosão mas com um gemido."
} 
maneira o mundo acaba: não com uma explosão, mas com um gemido). Assim, a estrofe poderia ser simplesmente:

This is the way the world ends

Not with a bang but a whimper.

A questão que se coloca é: a que vem essa insistência no primeiro verso. O que essa repetição produz, na verdade, é o crescimento da expectativa. Uma ocorrência do verso sem resposta soa incompleta e, portanto, convida a uma conclusão:

This is the way the world ends

Três ocorrências, porém, são desconcertantes:

This is the way the world ends

This is the way the world ends

This is the way the world ends

A reapresentação de algo já conhecido não traz surpresas e, por isso, poderíamos esperar uma tensão descendente à medida que os versos se repetem. Entretanto, vemos que a cada ocorrência cresce nossa expectativa, como se o poema não apenas nos convidasse para uma conclusão (como no uso do demonstrativo "this"), mas antes nos preparasse para ela. A repetição está nos levando na direção de um máximo de tensão. O verso final é, nesse contexto, a virada que resolve a tensão. Em razão do crescimento de tensão que lhe antecedeu, essa virada é altamente concentrada e eficaz. Ela se configura como um clímax do texto. 
Por terminar nesse ponto, ou seja, por resolver a tensão, mas não oferecer um desdobramento posterior, o poema de Eliot deixa o enunciatário sob o efeito do impacto, que só pode se resolver a posteriori. A eficácia do texto está em parte na força do impacto resolvido, mas não elaborado; na necessidade de retomada dos conteúdos desenvolvidos no texto (Lemos, 2010 :91-93). Essa estratégia responde de certa forma pelo caráter circular da poesia, pela ideia que o poema se dobra sobre si mesmo e que o fim é um convite para o recomeço.

Ainda vamos tratar mais detidamente da repetição como agenciadora da espera no texto. Por ora, resta-nos ainda determinar quais repetições são relevantes para a criação desse efeito. Em outras palavras, quais são as condições textuais necessárias para que a repetição possa ser usada como uma estratégia de gestão do ritmo do conteúdo?

Poderíamos supor, preliminarmente, que uma certa relação hierárquica estaria em jogo e partiríamos de uma divisão por níveis de análise linguística (Benveniste, 1995). Esse não deixa de ser um caminho plausível e foi, em grande medida, aquele empreendido por Frédéric em sua classificação "formal", isto é, segundo a extensão sintagmática do elemento repetido. Assim, quando menciona repetições da expressão (como, por exemplo, aliterações e assonâncias em textos verbais), reiterações lexicais ou sintáticas, a autora está se fiando justamente nessa tradição de classificação por níveis de análise. O contraste de dois exemplos de uso de rimas, porém, prova o contrário: essa não pode ser a via de explicação, visto que, num mesmo 
nível de análise, o efeito ora se confirma, ora não. Comecemos por "The Raven" de Edgar Allan Poe (1996: 92-98):

Once upon a midnight dreary, while I pondered, weak and weary,

Over many a quaint and curious volume of forgotten lore -

While I nodded, nearly napping, suddenly there came a tapping,

As of some one gently rapping, rapping at my chamber door.

"Tis some visiter," I muttered, "tapping at my chamber door -

Only this and nothing more."

Ah, distinctly I remember it was in the bleak December;

And each separate dying ember wrought its ghost upon the floor.

Eagerly I wished the morrow; - vainly I had sought to borrow

From my books surcease of sorrow - sorrow for the lost Lenore -

For the rare and radiant maiden whom the angels name Lenore -

Nameless here for evermore.

$[\ldots]$

And the Raven, never flitting, still is sitting, still is sitting

On the pallid bust of Pallas just above my chamber door;

And his eyes have all the seeming of a demon's that is dreaming,

And the lamp-light o'er him streaming throws his shadow on the floor

And my soul from out that shadow that lies floating on the floor

Shall be lifted - nevermore!

Marcamos nos trechos escolhidos uma sequência de rimas que permeia todo o poema. A sequência [ə.].] se repete sistematicamente nos mesmos versos e encerra assim quatro dos seis versos de cada estrofe, ou seja, é a 
rima mais recorrente do poema. Além disso, ela está no nome da amada perdida, Lenore, e na palavra "nevermore", que condensa a constatação do eu poético de que sua amada nunca retornará. O poema de Poe traz tanto no seu tema quanto na sua amarração sonora uma circularidade. Assim como o eu poético dá voltas em torno da memória de sua amada sem conseguir dela se desfazer, também os sons vão e voltam sem avançar. A insistência nesses sons vai contribuir para um crescimento da tensão. Numa estratégia diferente da empregada por Eliot, "The Raven” não conta com uma resolução. O poema permanece por toda sua extensão na continuação da parada. O eu poético está para sempre preso na impossibilidade de distensão.

Dessa maneira, pela insistência exponencial nos mesmos sons, por sua associação a dois vocábulos centrais e seu laço com o tema de mesma cifra tensiva, a repetição sonora nesse texto é primordial. Ela está posta em primeiro plano e age diretamente na construção da tensão.

Vejamos agora um exemplo em que a trava sonora é também significativa, mas não desempenha um papel semelhante. Tomemos o soneto CXXX de Shakespeare (1996:160):

My mistress' eyes are nothing like the sun;

Coral is far more red than her lips' red;

If snow be white, why then her breasts are dun;

If hair be wires, black wires grow on her head.

I have seen roses damasked, red and white,

But no such roses see I in her cheeks;

And in some perfumes is there more delight 
Than in the breath that from my mistress reeks.

I love to hear her speak, yet well I know

That music hath a far more pleasing sound;

I grant I never saw a goddess go;

My mistress when she walks treads on the ground.

And yet, by heaven, I think my love as rare

As any she belied with false compare.

Nesse caso, usamos duas formas diferentes de marcar as rimas para enfatizar o esquema $A B A B$ que muda a cada estrofe e o esquema AA na última. Trata-se de forma rígida, à maneira de uma receita. Ora, o poeta faz uso inteligente da forma. Num poema metalinguístico que põe em jogo precisamente os lugares comuns da poesia lírica, a forma do soneto ganha também um estatuto problematizado. A rima não é mero enfeite e contribui para o sentido global. Ainda assim, essa repetição sonora não age sobre a tensão do texto da mesma forma. Aliás, ela parece estar em relativo segundo plano, se comparada com a do texto de Poe.

Estamos diante de duas ocorrências de repetição sonora em situação de rima. No entanto, a primeira é diretamente relevante para os efeitos que estamos investigando, enquanto a segunda parece ser menos pertinente. A resposta à pergunta que nos colocamos acima parece então não estar no nível de análise como supusemos inicialmente, mas na relativa saliência da repetição. Em Poe, a repetição aparece em primeiro plano, enquanto em Shakespeare ela surge como um quadro estruturante. Em Poe, ela é figura. Em Shakespeare, ela faz o fundo. 


\subsection{A Repetição como Fundo ou Figura}

Se nossa hipótese está correta e a relevância da repetição para os efeitos que estamos analisando está ligada à sua posição relativa de figura ou fundo na construção textual, é preciso redirecionar a discussão.

As noções de figura e fundo são, na verdade, maneiras de descrever o "mecanismo geral por meio do qual a linguagem estabelece um conceito como ponto de referência ou âncora de um outro conceito" (Talmy, $2000: 311) .^{2}$ Eles estão em jogo na noção de forma da teoria da Gestalt e, portanto, "[n]a determinação recíproca do todo e das partes, e [n]o caráter intrinsecamente transponível das formas (de um contexto ou de um meio a um outro)" (Cadiot \& Visetti, $2001: 52){ }^{3}$

Dentro do esquema de formas da Gestalt, fundo e figura sugerem uma série de oposições caracterizantes de um ou de outro dos termos do binômio. Leonard Talmy (2000:315-316) propõe uma série dessas características, mas avisa que apenas as seguintes noções bastante vagas podem ser ditas de cada um:

Figura: tem propriedades espaciais (ou temporais) desconhecidas a serem definidas

Fundo: age como uma entidade de referência e tem propriedades conhecidas que podem caracterizar as propriedades desconhe-

\footnotetext{
${ }^{2}$ Tradução nossa para: "pervasive system by which language establishes one concept as a reference point or anchor for another concept".

${ }^{3}$ Tradução nossa para: "[dans] la détermination réciproque du tout et des parties, et [dans] le caractère intrinsèquement transposable des formes ( $d^{\prime}$ un contexte ou d'un milieu à un autre)".
} 
cidas da Figura ${ }^{4}$

As demais características são, na verdade, tendências a serem especificadas em cada contexto. Para a posição da repetição nos textos, discutiremos algumas características levantadas por Cadiot \& Visetti (2001 : 55-59), que organizamos no quadro abaixo:

\begin{tabular}{cc}
\hline Figura & Fundo \\
\hline \hline mais saliente & menos saliente \\
\hline mais recentemente presente na cena & mais familiar ou esperado \\
\hline resistente à mudança & mais variável \\
\hline mais homogêneo & menos homogêneo \\
\hline
\end{tabular}

Tomemos uma publicidade do site de compras pela internet Submarino. ${ }^{5}$ Nesse vídeo, encontramos diversos elementos repetitivos: a disposição sintagmática que organiza o aparecimento e o desaparecimento das palavras na tela; o grafismo e os traços plásticos das palavras e das letras; os traços de sentido em comum que reúnem os diversos termos propostos num paradigma de objetos ao mesmo tempo cotidianos e fantasiosos.

Nesse contexto, o que é fundo e o que é figura? Do ponto de vista estritamente visual, a tela branco-acinzentada é o fundo onde surgem a cada momento novas palavras-objeto. Por outro lado, se tomarmos a

\footnotetext{
${ }^{4}$ Tradução nossa para: “Figure: has unknown spatial (or temporal) properties to be determined" e "Ground: acts as a reference entity, having known properties that can characterize the Figure's unknowns".

${ }^{5}$ Para assistir a essa publicidade pela internet, acessar o link: https://www.youtube.com/watch? $v=$ hebUwW3Nv2M. Para uma análise detalhada do vídeo, ver Lemos $(2010: 26-40)$. Os aspectos que trataremos aqui não foram abordados naquela análise.
} 
primeira característica proposta no quadro, veremos um deslocamento da saliência a cada etapa de apresentação dos objetos:
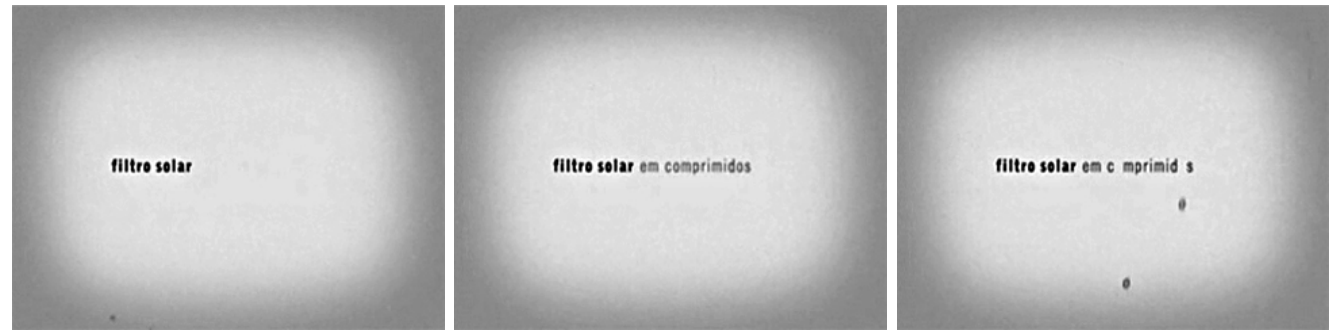

Figura 3.1 - Submarino - sequência "filtro solar em comprimidos"

Em primeiro lugar, vemos surgir na tela a sequência "filtro solar", único elemento que se destaca do fundo cinza. Em seguida, nossa atenção se dirige à segunda parte do sintagma. Apesar de ser apresentado em fonte mais clara, as palavras "em comprimidos" ganham saliência porque surgem onde não havia nada - são o elemento novo. As palavras "filtro solar" ficam em segundo plano. Elas são o suporte para o entendimento de "em comprimidos" que por si só ficaria perdido no contexto. Ora, se o primeiro bloco passa a ser entendido como informação dada, como menos saliente, e, principalmente, como ponto de referência para o segundo bloco, podemos então afirmar que "filtro solar" passou de figura a fundo.

Mais ainda, é com a entrada do segundo elemento que temos a leitura fantasiosa de que falávamos. "Filtro solar" em si é apenas um objeto cotidiano. É o modificador "em comprimidos" que lhe atribui o caráter inusitado. Sendo assim, a segunda parte modifica o sentido do primeiro termo. Assim, ao passar ao estatuto de fundo, de suporte para a figura que virá, o primeiro termo torna-se mais variável, e sua interpretação é passível 
de flutuações. A entrada do segundo termo desloca o sentido do primeiro.

Poderíamos sustentar o mesmo argumento para a interpretação do segundo elemento, uma vez que ela é dependente do sentido do primeiro. No entanto, os casos são distintos e a questão do tempo entra em jogo. Para "filtro solar", há um momento T1 em que o interpretamos como algo próximo de seu sentido literal. Em seguida, no momento T2 de entrada de "em comprimidos", reinterpretamos o primeiro. Para o segundo termo, nunca houve essa diferença de momentos. Sempre vamos interpretá-lo nesse sentido deslocado de um objeto que - por enquanto - não existe. O que explica a função de referente de "filtro solar" é justamente o seu estatuto de fundo. Segundo a definição mais geral de Talmy, que repetimos aqui, o fundo "age como uma entidade de referência e tem propriedades conhecidas que podem caracterizar as propriedades desconhecidas da Figura".

Temos assim um encadeamento sintagmático, certa linearidade temporal que gera um deslocamento no papel dos elementos no texto. Em função do momento de entrada no campo de presença e de seu papel na interpretação dos elementos seguintes, cada parte das palavras-objeto dessa publicidade funciona primeiro como figura e depois como fundo. No exemplo estudado, temos a entrada de "filtro solar" como elemento saliente. Em seguida, ele passa ao segundo plano para servir de referência para "em comprimidos". Ao final dessa sequência, todo o sintagma "filtro solar em comprimidos" passa a ser o suporte das variações gráficas, numa iconização das letras.

Essa etapa ilustra a última característica do quadro acima: a homogenei- 
dade. Segundo Cadiot \& Visetti, a figura é mais homogênea que o fundo. De fato, quando nos é apresentado "filtro solar em comprimidos", lemos o texto e apreendemos o seu sentido em bloco. Não separamos o sentido de cada palavra; não interpretamos os morfemas; não analisamos os sons. Certamente não nos atemos às letras que formam essas palavras. "Filtro solar em comprimidos" é um bloco coeso. No entanto, quando passa a compor o fundo, pode tornar-se heterogêneo e fragmentar-se para que suas partes (nesse caso as letras "o") ganhem traços icônicos dos objetos aludidos pelo texto verbal. Mais uma vez, como as letras-comprimido são agora a figura, sequer nos damos conta de que não se parecem tanto assim com comprimidos. Há apenas a circularidade e a alusão ao peso (por meio da queda representada) como traços icônicos. Em nossa experiência cotidiana, comprimidos não são cinzas com bordas pretas, não são objetos de duas dimensões. Entretanto, nada disso importa, pois sua posição de figura garante a homogeneidade.

\subsection{Da Relação Fundo-Figura ao Encadeamento Temporal}

As noções de figura e fundo colocam em foco relações espaço-topológicas. Nos quadros da Linguística Cognitiva, o espaço ocupa um papel totalizante:

Assim, o quadro de instauração de toda significação seria, então, "espacial", num sentido alargado do termo que vai da simples metáfora perceptiva à abstração topológica matematizável. (Cadiot \& Visetti, 
$2001: 8)^{6}$

Para podermos abordar a repetição nos termos que estamos propondo, teremos também que operar uma metaforização desses conceitos de base espacial. Como vimos acima, a sucessão temporal está no cerne da interpretação das figuras que se transformam em fundo no processo em cadeia descrito. Ademais, a leitura do que é fundo e do que é figura nas duas primeiras partes (ver Figura 3.1) está ligada antes ao seu conteúdo nocional que à disposição topológica na tela. ${ }^{7}$ Assim, voltamos aqui a um argumento que levantamos acima na discussão acerca do poema de Eliot.

A publicidade do Submarino é organizada por uma longa frase que se inicia com o vídeo e termina em seus segundos finais. $\mathrm{O}$ filme começa pelo condicional: "e se existisse...". Lista uma série de objetos cotidianos e fantasiosos como o "filtro solar em comprimidos" já mencionado. Ele fecha a frase na forma de uma pergunta: "você compraria?". Em seguida, comenta uma suposta resposta afirmativa do telespectador com a frase: "A gente venderia". Encerra-se com o nome e o logotipo da empresa.

Fizemos então o mesmo exercício que propusemos nos comentários sobre a estrofe final de "The Hollow Men". Pusemo-nos a pergunta: será preciso repetir tantas vezes a fórmula? Precisamos de tantos objetos? Para transmitir o cerne da mensagem, basta um:

\footnotetext{
${ }^{6}$ Tradução nossa para: “Ainsi donc, le cadre d'installation de toute signification serait "spatial", en un sens élargi du terme qui va de la simple métaphore perceptive à l'abstraction topologique mathématisable."

${ }^{7} \mathrm{O}$ mesmo não pode ser dito do terceiro momento (terceira imagem da Figura 3.1), pois as relações topológicas entre figura e fundo seguem literalmente as relações espaciais trabalhadas por Talmy $(2000: 311-317)$.
} 

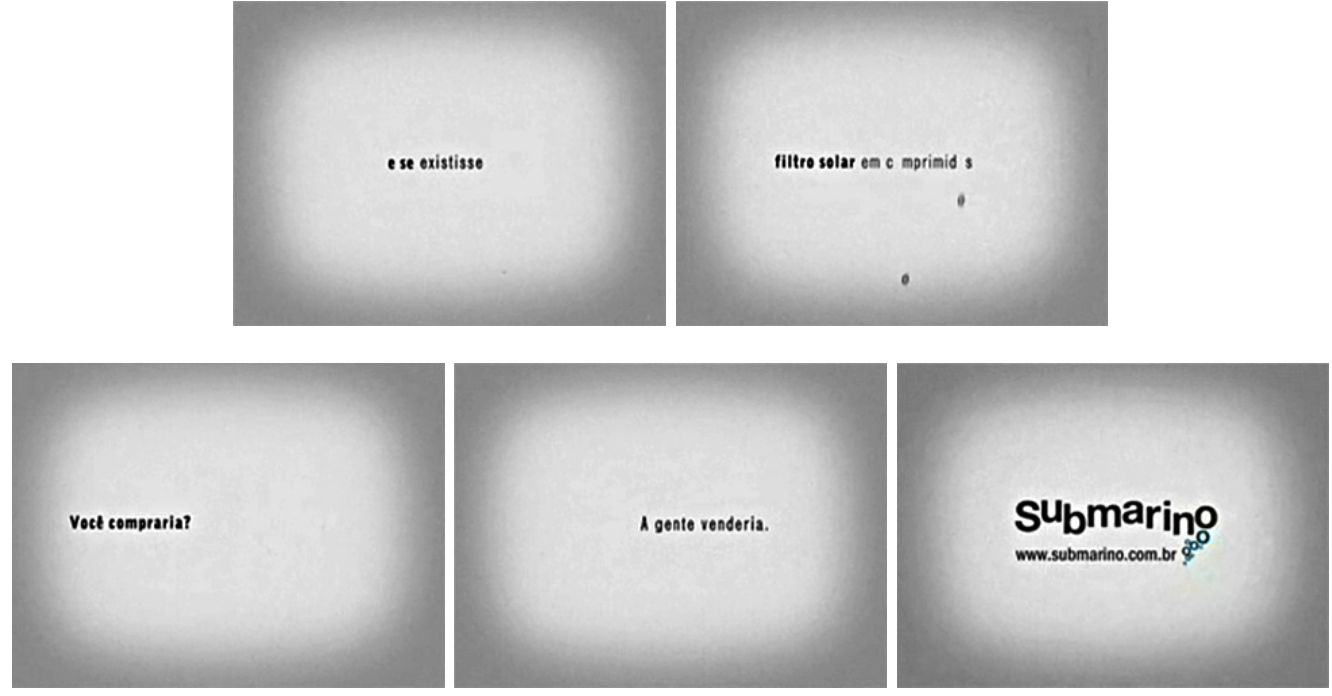

Figura 3.2 - Submarino - sequência global

Nesse caso, como no caso de Eliot, perdemos o efeito de tensão crescente criado pela repetição. Até então, nosso exercício não nos trouxe mais sobre o nosso fenômeno do que o que já tínhamos visto com a poesia.

Entretanto, note-se que essas imagens estáticas também transmitem a mensagem. Mesmo o jogo com as letras-comprimido está presente. Os cinco quadros reorganizados em um só poderiam até formar um cartaz, ou vários - um para cada objeto: jornal que não voa na praia; sapatos de sapateado para cachorro; papel higiênico com as últimas notícias; etc.
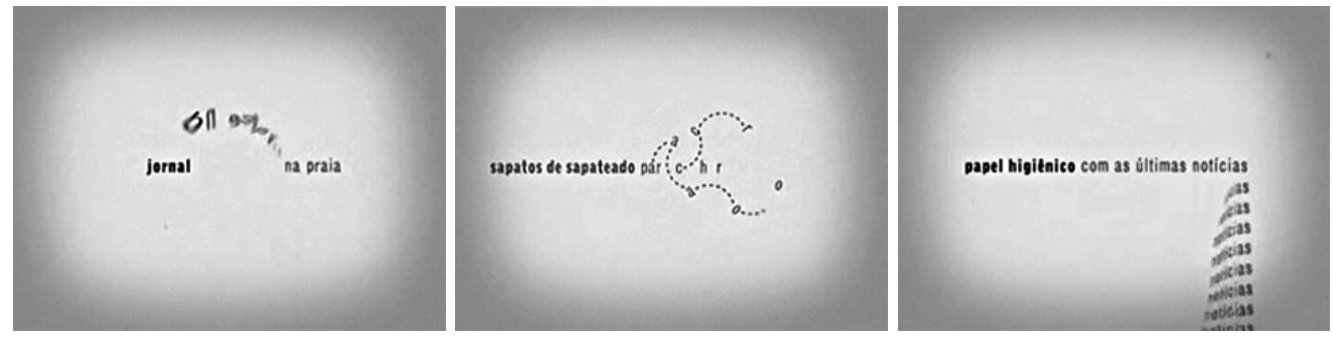

Figura 3.3 - Submarino - três palavras-objeto 
Esse gênero de série de cartazes não é incomum no meio publicitário:

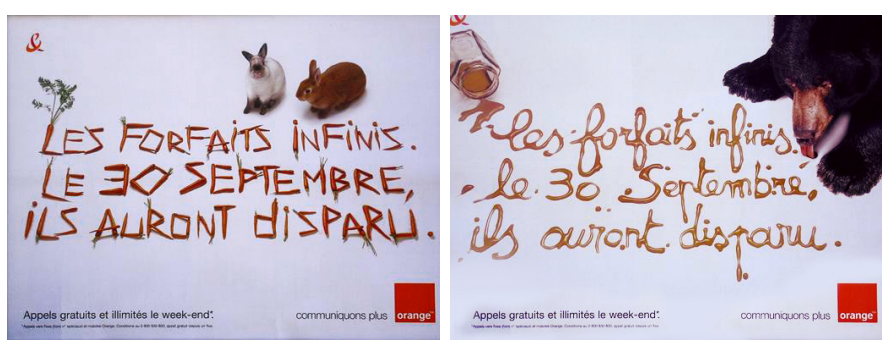

Figura 3.4 - Orange

Apesar de vermos "repetidos" os mecanismos e diversos traços também nos elementos seriais, não há a mesma criação de tensão que dirige a um clímax. Esse efeito está perdido. É preciso, portanto, diferenciar as construções em série das construções por repetição.

A nosso ver, a questão central é que nas séries de cartaz não há um encadeamento necessário. O enunciatário não deve seguir sempre uma determinada ordem, nem exaurir a série para apreender o sentido proposto. No vídeo, o componente temporal é primordial, mas ainda mais relevante é a linearidade - fator que não está em jogo da mesma maneira na imagem estática. Diferentemente de objetos que se desenrolam no tempo, como textos verbais, musicais e fílmicos, um objeto visual estático não conta com um encadeamento sintagmático necessário. O percurso interpretativo é sempre linear, uma vez que é difícil supor uma apreensão total e instantânea, que descarte qualquer forma de segmentação, mas também porque o discurso interpretativo tende a ser verbal, e portanto linear. No entanto, essa linearidade não é determinada pelo objeto. Podemos fazer uma leitura da direita para a esquerda, ou vice-versa; de cima para baixo, ou de baixo 
para cima; do centro para as bordas... (Lemos, 2013 : 13). Não somente o enunciatário pode percorrer cada cartaz diferentemente, como também não há uma ordem para a série. A direção está no percurso do olhar, não nas imposições do objeto.

Sendo assim, além da relação figura e fundo que exploramos acima, um outro fator necessário para a constituição do efeito de organização do fluxo textual e de uma certa criação de expectativa é a linearidade.

\subsection{Considerações sobre a Noção de Linearidade}

\subsubsection{Sintagma e Texto}

Dizer que o efeito de organização do fluxo textual está atrelado à noção de linearidade não é uma afirmação banal, pois vimos que o percurso textual determina em parte a interpretação dos conteúdos e certamente age sobre as possibilidades de estruturação do texto. Ao mesmo tempo, Saussure (1997: 84) define a linearidade em função da materialidade do significante, ou seja, porque é de natureza auditiva, o significante é "mensurável numa só dimensão: é uma linha". Em poucas palavras, se a linearidade é estruturante dos conteúdos do texto, mas ao mesmo tempo é determinada pela manifestação, tudo se passa como se a matéria - ou na melhor das hipóteses, a substância - determinasse a forma. É de fato assim que interpretam alguns dos estudiosos das anotações que embasaram a escritura do Curso de Linguística Geral (CLG):

é apenas no último curso que ele [Saussure] formula o princípio da 
linearidade do significante como laço entre esses dois fenômenos: ao mesmo tempo causa da linearidade sintagmática ("Se nós podemos recortar as palavras nas frases, isso é consequência desse princípio") e consequência da linearidade acústico-articulatória da fala ("Isso decorre do fato de que é acústico"). (Testenoire, 2014:13) ${ }^{8}$

Ora, numa teoria que se pretende imanente, é a forma que deve determinar a substância. A constatação que fizemos acerca do papel da linearidade parece entrar em conflito com a teoria da linguagem que vimos adotando e uma melhor definição do fenômeno se faz necessária.

Na sequência do CLG, vemos que, além de definir o signo, o princípio da linearidade afeta também o sintagma:

no discurso, os termos estabelecem entre si, em virtude de seu encadeamento, relações baseadas no caráter linear da língua [... ] Tais combinações, que se apoiam na extensão, podem ser chamadas de sintagmas. [...] Colocado num sintagma, um termo só adquire seu valor porque se opõe ao que o precede ou ao que o segue, ou a ambos. (Saussure, $1997: 142$ )

É essa segunda menção ao conceito que faz com que Testenoire (2014:3) reconheça dois aspectos da linearidade: de um lado, ela define um caráter do significante, de outro, responde por uma característica da língua.

Encontramos na linearidade pensada em termos sintagmáticos ressonância ao caráter estruturante discutido acima:

\footnotetext{
${ }^{8}$ Tradução nossa para: “ce n'est que dans le dernier cours qu'il [Saussure] formule le principe de la linéarité du signifiant comme lien entre ces deux phénomènes: à la fois cause de la linéarité syntagmatique ('Si nous pouvons découper les mots dans les phrases, c'est une conséquence de ce principe') et conséquence de la linéarité acoustico-articulatoire de la parole ('Cela découle de ce qu'il est acoustique')."
} 
Como suas grandezas [as da gramática] são formais e a forma vem dada pelas dependências que adquirem essas grandezas, a grandeza isolada só é definível por suas possibilidades de relação. Isto é, uma unidade pleremática de um paradigma (aproximadamente uma "palavra" na "morfologia") é definida por suas funções na cadeia (aproximadamente por suas funções "sintáticas"). (Llorach, 1972:51)9

Se, como Llorach, reconhecemos nos estudos desenvolvidos neste Capítulo o papel estruturante da organização em cadeia, somos levados a concluir o inverso do proposto por Testenoire. A linearidade do significante não pode ser "a causa da linearidade sintagmática e a consequência da linearidade acústico-articulatória". Esse tipo de construção de causa e efeito busca a origem da língua no ato fundador inatingível, nas restrições materiais que estariam na raiz da constituição da língua como a vemos hoje. Dizer que a nossa língua se tornou linear porque o nosso aparelho fonatório não é capaz de produzir sons simultâneos é uma especulação relativamente plausível, mas só subsiste no mundo das suposições e, principalmente, não revela muito de como se organiza a língua que temos hoje.

O que importa de fato é que, uma vez estabelecidas as restrições formais que são próprias à língua, elas se tornarão necessárias e determinarão o uso. Elas são, portanto, estruturantes: a regra convencionada - qualquer que seja a sua origem última — deve ser seguida por todos os falantes da língua. É assim que aquilo que era visto como causa (a linearidade acústico-

\footnotetext{
${ }^{9}$ Tradução nossa para: "Como sus magnitudes son formales y la forma viene dada por las dependencias que adquiren esas magnitudes, la magnitud aislada sólo es definible por sus posibilidades de relación. Esto es, una unidade pleremática de un paradigma (aproximadamente una 'palabra' en 'morfología') es difinida por sus funciones en la cadena (aproximadamente por sus funciones 'sintáticas')."
} 
articulatória) será na verdade a manifestação de uma estrutura subjacente: a sintagmática. Num percurso diferente, Hjelmslev (apud Zinna, 1995 : 256257) discute o papel da linearidade não apenas para o significante, mas também para o significado. Ao mostrar que ambos estão submetidos a esse princípio, o linguista dinamarquês conclui que o princípio da linearidade é mais abrangente que o significado e o significante tomados isoladamente. A linearidade é, portanto, um princípio da língua e não da fala.

Essa conclusão é pertinente dentro da teoria saussuriana, na qual língua e fala perfazem uma das oposições consagradas do CLG. Entretanto, na teoria hjelmsleviana, a língua não recobre exatamente o mesmo campo que abarcava para Saussure. Se desejamos permanecer fiéis à epistemologia de Hjelmslev, a oposição relevante será língua e texto, nos termos discutidos no Capítulo $2 .{ }^{10}$ De fato, para explicar a noção de linearidade, Hjelmslev (1991b:55-56) propõe voltarmo-nos para a observação do texto manifestado:

Em se tratando de um texto impresso ou escrito, vemos que ele é composto de signos, e que estes são compostos, por sua vez, de elementos que se desenrolam numa direção determinada [...] e quando ouvimos um texto falado, ele se compõe de signos, e esses signos são

\footnotetext{
${ }^{10}$ Estabelecer correspondências entre teorias é de grande risco, mas a passagem da oposição língua vs. fala para língua vs. texto nos convida a comentar sobre a abrangência desses dois termos. Se Hjelmslev considera que o caráter sintagmático da linearidade determina sua posição como um fenômeno da língua (e não da fala), isso nos leva a concluir que a língua saussuriana, para os efeitos da discussão empreendida aqui, abarca as noções hjelmslevianas de língua e texto. Em outros termos, a língua saussuriana inclui relações sintagmáticas e relações associativas (grosso modo, a paradigmática), enquanto essas duas derivações se configuram exatamente no elemento diferenciador para Hjelmslev: o texto é uma sintagmática e a língua é uma paradigmática. À fala saussuriana corresponde um terceiro conceito hjelmsleviano: a manifestação.
} 
compostos, por sua vez, de elementos que se desenrolam no tempo:

alguns vêm antes, outros depois. ${ }^{11}$

A constatação é perfeitamente plausível e encontra ressonância em nossa experiência cotidiana com textos verbais. Ainda que o exercício perceptivo proposto por Hjelmslev ajude a enxergar o fenômeno, vimos que o texto semiótico não se limita à empiria, mas deve ser sobretudo um objeto analisado para que possa ser verdadeiramente apreendido como tal. Também nesse sentido, o princípio da linearidade parece estar ligado à noção de texto, e não da língua, uma vez que já aparece formulado por Saussure como uma propriedade da cadeia sintagmática, que é a própria definição de texto para Hjelmslev. ${ }^{12}$ Isso também é coerente com a nossa conclusão de que a repetição é um fenômeno do texto. Se ela é dependente da linearidade, é de se esperar que ambas sejam fruto da mesma derivação, ou seja, da análise sintagmática.

A questão que resta a resolver é que nem toda sintagmática é linear. As semióticas planares, como a fotografia e a pintura, parecem criar um arranjo simultâneo de suas partes e manifestam seus significados em duas dimensões, no lugar da dimensão única da semiótica verbal (Fiorin, 2014:30-31). Para o Dicionário de Semiótica (Greimas \& Courtés, 2011 : 288), linearização implica tanto as contiguidades temporais quanto espaciais, sendo assim uma tarefa da textualização em geral. Essa definição é por demais ampla

\footnotetext{
${ }^{11}$ Tradução nossa para: "En regardant un texte imprimé ou écrit, nous voyons qu'il se compose de signes, et que ceux-ci se composent à leur tour d'éléments qui se déroulent dans une direction déterminée [...] et lorsque nous les entendons un texte parlé, il se compose pour nous de signes, et ces signes se composent à leur tour d'éléments qui se déroulent dans le temps: certains viennent avant, d'autres après."

${ }^{12}$ Lembramos que "texto" é uma sintagmática de uma semiótica denotativa.
} 
para o escopo desta tese, uma vez que mostramos que a sucessão e a ordem unidimensional trazem consequências específicas para a construção da espera. Sendo assim, é importante distinguir essas duas formas de manifestação sintagmática. Fiaremo-nos então na etimologia da palavra "linearidade" para considerar essa manifestação numa única dimensão e adotaremos, sem nos aprofundar no assunto, o nome de "simultaneização", proposto por Fiorin $(2014: 31)$, para a textualização de semióticas planares. Não cabe, portanto, dizer que a linearidade é $a$ manifestação da função sintagmática, mas ela é uma manifestação possível — outra sendo o arranjo espacial, por exemplo. ${ }^{13}$ As consequências dessa oposição ainda não estão claras e um estudo mais aprofundado acerca da linearidade levaria mais longe suas condições e suas consequências. No entanto, não podemos aqui perder de vista o nosso foco na repetição. Para tanto, o que nos interessa é esse caráter estruturante da sintagmática manifestada em sua linearidade.

\subsubsection{Tempo e Leitura}

Uma questão relacionada é a associação da linearidade com o tempo. A problemática que pode resultar dessa aproximação não é imediatamente perceptível, uma vez que o próprio Saussure apresenta as duas noções conjuntamente, definindo uma pela outra: "O significante, sendo de natureza auditiva, desenvolve-se no tempo, unicamente, e tem as características que

\footnotetext{
${ }^{13}$ Apesar de clássica a oposição entre planar e linear, tempo e espaço, não estamos em condições de afirmar aqui que esses sejam os únicos modos de textualização possível. É possível observar minimamente semióticas de manifestação híbrida, como as histórias em quadrinhos, que se servem tanto de estratégias espaciais como temporais para a construção de seus sentidos.
} 
toma do tempo" (Saussure, 1997: 84). De fato, comentadores como Michel Arrivé (1995) e Yong-Ho Choi (1996) consideram a linearidade como uma das formas de incursão do tempo na língua. Todavia, como discutido acima, a linearidade deve ser entendida como uma das manifestações possíveis da sintagmática e, portanto, suas características temporais também são a manifestação de um mecanismo mais profundo.

Pierre-Yves Testenoire (2014: 8) aponta que a unidimensionalidade do signo linguístico é na verdade a representação espacial de um fenômeno temporal. Ora, se estamos trabalhando na perspectiva semiótica em que se entende a manifestação de maneira mais larga a ponto de englobar o texto escrito, o filme, a história em quadrinhos, para citar alguns, podemos nos perguntar onde está o tempo no livro fechado ou no filme que permanece na bobina. ${ }^{14}$ Na realidade, visto que a linearidade é manifestação do mecanismo subjacente, é preciso supor que, como o espaço para Testenoire, o tempo é a representação que fazemos dele, ou seja, é um tempo enunciativo presumido. Em termos mais corriqueiros, a linearidade temporal corresponde a um suposto tempo de leitura ou tempo de assistência de um texto fílmico.

Nesses termos, não podemos falar de um tempo "de fato" ou "real", pois ele pode não vir a se realizar. Ao mesmo tempo, precisamos considerálo como elemento pertinente para a estruturação do texto. Se falamos então de tempo de leitura ou de assistência, estamos pendendo para o lado

\footnotetext{
${ }^{14}$ Os exemplos do livro fechado e do filme na bobina não ignoram o papel da atualização do texto. Sugerem tão somente a necessidade de dar conta do fenômeno em discussão também em seu caráter virtual e, com isso, garantir sua independência em relação à manifestação.
} 
interpretativo da noção globalizante de enunciação (Badir, 2009). Não ignoramos com isso o caráter necessariamente complexo dessa noção, apenas que o tempo visto nesses termos parece exigir a consideração do caráter interpretativo.

Se adotamos o tempo de leitura como parâmetro, voltamos à indiferenciação entre textos que "se desenvolvem" no tempo (tipicamente verbais e fílmicos) e textos que "se organizam" no espaço (tipicamente pinturas e fotografias), pois também é preciso considerar um tempo de apreensão destes últimos: um percurso interpretativo. Ainda assim, intuitivamente reconhecemos a diferença. Tudo se passa como se o percurso no primeiro caso fosse imposto pelo objeto e, no segundo, o percurso é de livre escolha do intérprete (Lemos, 2013).

Nossa discussão está deslizando na direção de uma explicação que transcende o texto. Para preservar a imanência, poderíamos passar a um nível superior de pertinência e dizer que, sendo uma questão de leitura, sua relevância está na cena predicativa, que insere o sujeito numa prática de leitura (Fontanille, 2006). Essa não nos parece uma solução possível, já que, nesse caso, deixaríamos o nível do texto enunciado, no qual as restrições sintagmáticas determinam a expressão dos signos e as propriedades sensíveis e materiais das figuras. Note-se na tabela abaixo, reproduzida de Fontanille (2006:238), que, se estivéssemos no nível das cenas, seriam consideradas as propriedades sensíveis do objeto e não mais as qualidades do texto enunciado. Tratar de cenas predicativas seria confundir níveis descritivos e, em última instância, evitar a questão. 


\begin{tabular}{lll}
\hline TIPO DE EXPERIÊNCIA & INSTÂNCIAS FORMAIS & INSTÂNCIAS MATERIAIS \\
\hline \hline Figuratividade & Signos & $\begin{array}{l}\text { Prop. sensíveis e mat. } \\
\text { das figuras }\end{array}$ \\
\hline $\begin{array}{l}\downarrow \\
\text { Interpretação }\end{array}$ \\
\hline Corporeidade
\end{tabular}

Figura 3.5 - Percurso gerativo do plano da expressão

Para explorar uma outra via, tomemos contraexemplos, ou seja, um texto verbal que busca subverter a linearidade e um texto visual que requer uma leitura consecutiva. ${ }^{15}$ Assim, propomos considerar o caso de O Jogo da Amarelinha, de Julio Cortázar. O autor anuncia na abertura do livro: “À sua maneira, este livro é muitos livros" (Cortázar, 1999:5), dizendo, com isso, que os capítulos não seguem uma encadeamento necessário e o leitor é livre para escolher a ordem que lhe convém. Poderíamos então supor que está aí um caso de texto verbal em que foi possível se desvencilhar da ordem linear. Entretanto, os limites dessa proposta se revelam prontamente: "mas é, sobretudo, dois livros. O leitor fica convidado a escolher uma das

\footnotetext{
${ }^{15}$ Não vamos utilizar aqui exemplos como a poesia visual ou as histórias em quadrinhos. Por serem textos sincréticos, sua manifestação é híbrida. Não se pode decidir se operam primariamente com o modo linear e são modificados pelo modo planar ou vice-versa.
} 
seguintes possibilidades". Cortázar propõe duas ordens de leitura: (a) do Capítulo 1 ao 56, onde o leitor encontrará uma marca de fim; ou ainda (b) começando pelo Capítulo 73, saltando para frente e para trás segundo uma lista traçada pelo autor e lendo, assim, todos os 155 capítulos do livro. Ora, há dois trajetos possíveis e dois trajetos não são a ausência de ordem, mas apenas duas ordens. Como sugere o autor, temos dois livros com alguns capítulos que coincidem.

Se formos mais longe e insistirmos na proposta inicial de todas as ordens possíveis, como sugeria o prefácio do livro, teríamos então a ausência de organização? Talvez pudéssemos chegar a dizer isso. Ainda assim, só sustentaríamos essa desorganização presumida num único nível da descrição: o dos capítulos. No interior dos capítulos, a ordem linear se mantém. Livros de poesia gozam de independência semelhante, já que os desmantelamos para fazer antologias. Também nesse caso, a desordem só vai até o nível do poema, visto que as antologias, em geral, transcrevem poemas inteiros. Numa última tentativa de romper com a linearidade num nível inferior, abrimos um livro a esmo, desrespeitando a sua divisão em capítulos ou arrancamos um pedaço de frase para fazer uma citação. O imperativo da linearidade é tal que ainda assim seremos inseridos imediatamente na sequência da frase, do sintagma, da palavra em busca do sentido. ${ }^{16}$

No outro polo, podemos supor estratégias de linearização da semiótica planar. Vejamos a imagem “The Gossips” de Norman Rockwell:

\footnotetext{
${ }^{16}$ Para o estudo da poesia, o GrupoMu (1980:57-58) propôs uma leitura tabular para os textos poéticos. Apesar de o discurso poético poder ser lido em múltiplas camadas que se sobrepõem, a leitura tabular pressupõe uma leitura linear logicamente anterior
} 


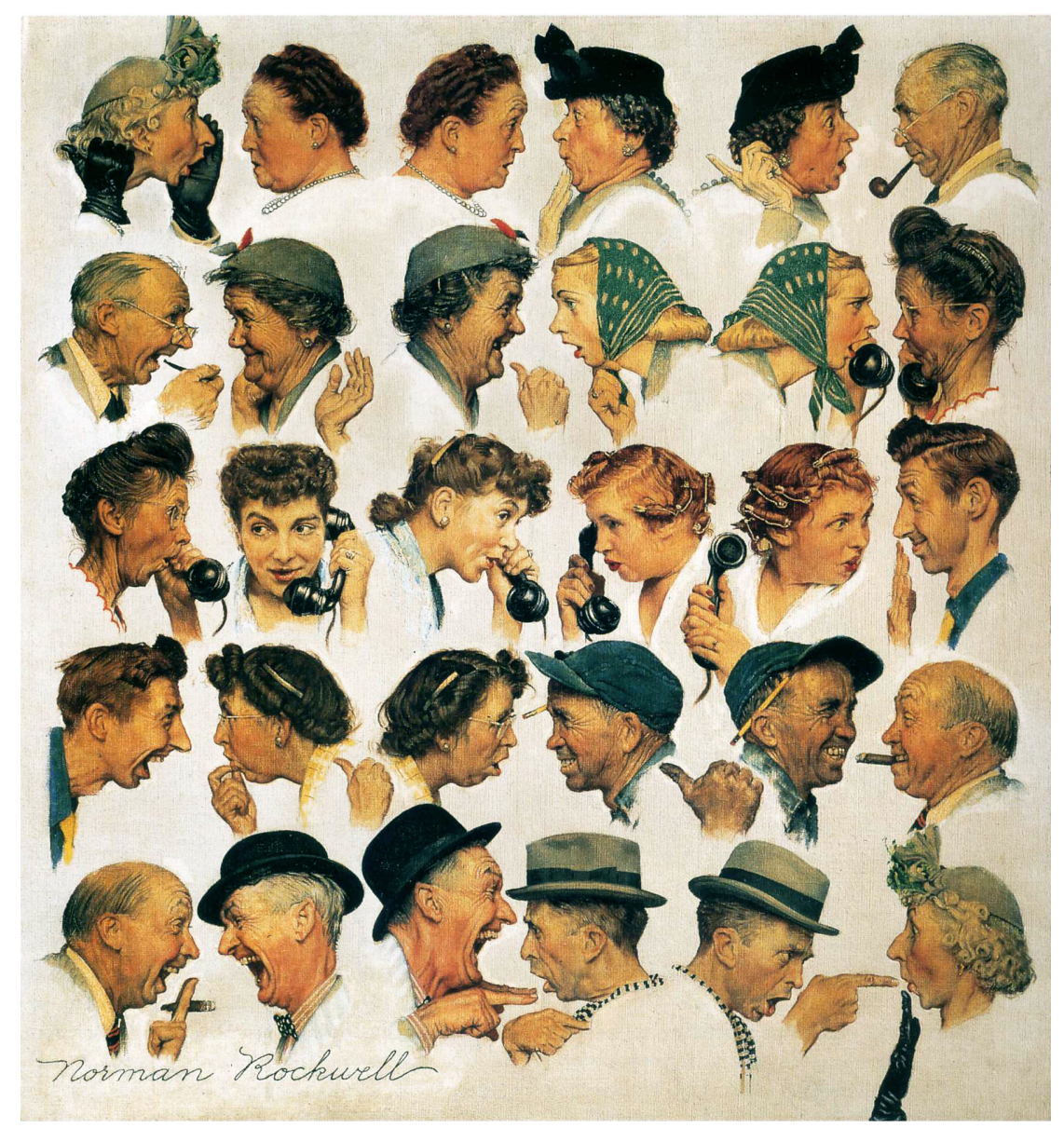

Figura 3.6 - Norman Rockwell — “The Gossips", 1948

Não há dúvida de que o pintor inseriu uma ordem linear que afeta o sentido da imagem. Ao mesmo tempo, como no exemplo do livro, essa subversão só se sustenta num dos níveis descritivos. Num plano inferior, onde recortamos cada uma das duplas de fofoqueiros, o arranjo é eminentemente planar; num plano superior, observamos uma totalidade que pode ser apreendida como tal. Sua sintaxe espacial não está suplantada, mas apenas problematizada.

Os exemplos nos mostram que é possível inserir elementos de outra 
ordem sintagmática num texto, mas essas inserções são excepcionais. São adições que podem gerar um certo hibridismo, como a imagem de Rockwell, que lembra histórias em quadrinhos, mas os textos não deixam de ser geridos por suas ordens planar ou linear, segundo o caso.

Retomando a argumentação apresentada antes dos exemplos, vimos que podemos supor um percurso de leitura para todo tipo de texto, mesmo os de organização planar, e que isso traz um problema à diferenciação entre as duas formas de arranjo sintagmático porque insere ambos os textos no tempo. Corremos novamente o risco de esbarrar na materialidade do significante para manter a diferença entre texto linear e texto planar. $\mathrm{Na}$ discussão dos contraexemplos, a resposta tanto para a organização sintagmática corrente como para sua alteração está ligada a uma segmentação do texto e estamos a todo tempo realizando leituras que abarcam o texto de forma mais global ou mais segmentada. Assim, o caráter linear ou planar da semiótica em questão é revelado pelo recorte na cadeia.

Voltando à discussão do Capítulo 2, um objeto qualquer só é texto se submetido à análise. Se, antes da análise, não podemos sequer tomá-lo como texto, certamente não podemos dizer nada de sua linearidade, de sua temporalidade ou de sua espacialidade. Assim, do ponto de vista semiótico, é a segmentação adequada que define (ou revela) a natureza de sua sintagmatização. ${ }^{17} \mathrm{O}$ indício desse caminho está na própria formulação de Saussure. Se, por um lado, começa sua definição de forma a atribuir à linearidade uma natureza concreta ("O significante, sendo de natureza auditiva, desenvolve-se no tempo"), o linguista genebrino a desenvolve

\footnotetext{
${ }^{17}$ Para o papel teórico da adequação ao objeto, ver Hjelmslev (2003: 15-17).
} 
em termos de representação e medida ("O significante [...] a) representa uma extensão, e b) essa extensão é mensurável numa só dimensão"). Sendo assim, apesar de encontrar expressão na materialidade que se desenvolve no tempo, a linearidade é antes o resultado da análise que estabelece sua forma e graduação. Numa semiótica planar, a segmentação adequada mostrará a influência da sintaxe espacial nos traços elencados. Já numa semiótica linear, a análise desvelará o papel da consecução no arranjo dos elementos.

\subsection{Contraste de Termos Relacionados}

Iniciamos esta tese apontando a amplitude do fenômeno da repetição e procedemos a sua delimitação progressiva: a opção pela semiótica, que estabelece o escopo geral (Capítulo 1), a apresentação das escolhas epistemológicas e o lugar teórico da repetição (Capítulo 2) e as condições textuais que determinam a pertinência da repetição (neste Capítulo 3). Se todo esse trajeto de redução e esses elementos sintagmáticos que se manifestam no que chamamos de linearidade são condições para os efeitos sobre o fluxo textual discutidos acima, muitos casos do que se diria repetição estão excluídos (como no exemplo do soneto de Shakespeare) e poderíamos nos perguntar se devemos de fato chamar o fenômeno sob escrutínio de repetição. Já buscamos, por exemplo, fazer uma diferença entre repetição e série, quando discutimos filmes e cartazes publicitários. No entanto, outros autores que discutiram o fenômeno chamaram-no redundância ou iteração, por exemplo. Assim, nos perguntamos qual é de fato a definição de repeti- 
ção? Não haveria um outro termo mais apropriado para as características levantadas?

Uma discussão contrastiva de termos próximos pode nos esclarecer o melhor nome a atribuir ao fenômeno. Não propomos uma tipologia e não buscamos exaustividade: isso seria contraditório à postura exposta acerca das listas retóricas. Apresentamos aqui uma discussão metateórica que, por meio do contraste de termos, encerrará o caminho de delimitação do que chamamos repetição. ${ }^{18} \mathrm{O}$ procedimento não é novo, afinal a definição pela negativa é parte do pensamento saussuriano. Ademais, esses passos nos permitirão retomar as características definidoras da repetição pertinente a este estudo.

\subsubsection{Identificação e Linearidade}

Antes de mais nada, para escolher os termos que são comparáveis à repetição, e que, portanto, poderiam substitui-lo, é preciso retornar à definição mínima do fenômeno discutida no Capítulo 2. Assim, o primeiro traço que um termo precisa sugerir é o da identificação na cadeia, ou seja, é preciso que itens individuais na cadeia sejam identificados como pertencentes à mesma categoria.

Dada essa primeira condição, comecemos pelo retorno à discussão da noção de série, que, nas artes, se constitui num todo coerente a partir de membros de "mesma natureza" ou semelhantes. Como vimos, o fator da

\footnotetext{
${ }^{18}$ Apoiamo-nos no Michaelis Moderno Dicionário da Lingua Portuguesa (http://michaelis.uol.com.br/moderno/portugues/) e no Trésor de la Langue Française informatisé (http:/ / www.cnrtl.fr/definition/) para levantar os traços pertinentes.
} 
retomada ou reaparição do mesmo está colocado, mas os efeitos discutidos não se verificam pois esse tipo de manifestação não pressupõe necessariamente a linearidade. Outros termos próximos são a imitação, que reproduz traços, sem uma exigência de coincidência total (podendo mesmo tomar a forma de uma paródia), e a reprodução, que se refere tanto à ideia de uma cópia ou imitação fiel, quanto à noção de procriação de seres e novos exemplares da mesma obra. Nesse sentido, a reprodução se aproxima da concepção de token, elemento único que aponta uma categoria geral, uma definição, um tipo (type). ${ }^{19}$

Por outro lado, podemos imaginar o caso inverso em que haveria linearidade, mas ausência de retomada. O termo variação se aproxima dessa definição e um bom exemplo desse aspecto linear e dessemelhante é a variação em música, na qual um tema é retomado a cada vez com alterações que exploram as possibilidades do sistema musical da época. Vemos pela própria formulação dada à questão que há um núcleo que é repetido, porém a escolha do termo "variação" toma o que é semelhante como dado e coloca em evidência as diferenças. Essa é afinal a condição de toda diferença: a existência de um núcleo ou ao menos um aspecto comum. Assim, não se trata de dizer que não há repetição na variação, apenas que não é isso o que o termo coloca em evidência.

\footnotetext{
${ }^{19}$ Para uma breve apresentação dos conceitos de type e token, consultar a Stanford Encyclopedia of Philosophy, disponível em: http:/ / plato.stanford.edu/entries/types-tokens/.
} 


\subsubsection{Identificação, Linearidade e Saliência}

Outras características a serem levadas em consideração são aquelas ligadas à noção de figura, na oposição a fundo discutida acima. Condensaremos aqui essa relação em sua resultante geral: a saliência. É a ausência desse traço que torna o termo redundância inadequado para descrever nosso objeto. Na linguística, a redundância é vista como necessária para a transmissão da mensagem, ou seja, é uma forma de compensar o ruído que pode impedir a apreensão de partes do enunciado (Frédéric, 1985: 84-86). Independentemente das razões para sua existência, a redundância se realiza por meio de repetições gramaticalmente determinadas, como a concordância de número e gênero na língua. Em função de sua obrigatoriedade, a redundância não pode ser explorada na constituição do texto, como é o caso para outras formas de repetição facultativas.

O curioso é que, numa outra acepção — talvez mais corrente -, redundância conota exatamente o oposto, contando com traços de abundância e excessividade. Tudo se passa como se representasse exatamente o polo oposto ao de sua primeira acepção numa escala de extensidade da repetição. Num extremo, temos a repetição mínima que garante a coesão e a possibilidade de interpretação de um texto: trata-se da acepção linguística de redundância. No outro polo, encontramos a redundância entendida como excessiva, em que justamente a multiplicação pode afetar a compreensão do texto ou a atenção de um suposto enunciatário. Entre os dois limites, ocupando o comprimento da escala, estão todas as retomadas que ultrapassam esse limite mínimo e que, portanto, podem ser manipuladas no texto 
para criar variações de ritmo, andamento, espera, mas que não chegam a saturar a mensagem. É este último tipo de repetição que é nosso objeto de estudo. Nos termos de Claude Zilberberg (2011b:49-66), construímos uma sintaxe da repetição:

\begin{tabular}{|c|c|c|c|c|}
\hline \multirow[b]{2}{*}{$\begin{array}{l}\text { somente } \\
\text { menos }\end{array}$} & retomada & $\begin{array}{l}\text { progressão / } \\
\text { ampliação }\end{array}$ & recrudescimento & \multirow[b]{2}{*}{$\begin{array}{l}\text { somente } \\
\text { mais }\end{array}$} \\
\hline & $\begin{array}{l}\text { retirada de pelo } \\
\text { menos um menos }\end{array}$ & $\begin{array}{l}\text { retirada de mais de } \\
\text { um menos / } \\
\text { acréscimo de pelo } \\
\text { menos um mais }\end{array}$ & $\begin{array}{l}\text { acréscimo de mais } \\
\text { de um mais }\end{array}$ & \\
\hline 4 & & & & $\longrightarrow$ \\
\hline $\begin{array}{l}\text { ausência de } \\
\text { repetição }\end{array}$ & $\begin{array}{c}\text { redundância } \\
\text { linguística }\end{array}$ & repetição & $\begin{array}{c}\text { redundância } \\
\text { excessiva }\end{array}$ & $\begin{array}{l}\text { saturação de } \\
\text { repetição }\end{array}$ \\
\hline
\end{tabular}

Figura 3.7 - Sintaxe extensiva da repetição

Estamos cientes de que, na proposta de Zilberberg, "somente mais" e "somente menos" perfazem o ponto inicial e final da escala. Entretanto, por adequação ao objeto de pesquisa, decidimos considerar esses extremos como a ultrapassagem do limite, tomando as duas acepções de redundância como as fronteiras da escala. Como será discutido no Capítulo 4, a ausência total de reiteração e igualdades, de um lado, e a repetição total sem possibilidades de diferença, de outro, são perspectivas eminentemente especulativas, não produzindo textos interpretáveis.

Dizemos que a repetição pertence à dimensão da extensidade porque os intervalos se contam e não se medem, como na sintaxe intensiva (Zilberberg, 2011b:49-50; 121-122). A repetição é uma manifestação possível da intensidade manifestada, ou seja, da tonicidade e do andamento do texto. 
Assim como a intensidade rege a extensidade no esquematismo tensivo, a repetição está a serviço dos efeitos de sentido buscados. É essa relação de manifestação, isto é, o laço que se estabelece entre a repetição e seu efeito possível, que discutiremos no próximo capítulo e ilustraremos nas análises.

Com as comparações acima, percorremos todos os critérios relevantes e mostramos a inadequação dos sinônimos de repetição para a descrição do fenômeno estudado. Sobretudo, delimitamos por exclusão o campo do que escolhemos chamar repetição. Ainda assim, dois termos muito próximos do sentido de repetição merecem breves comentários. Primeiramente, a noção de recorrência, frequentemente usado como sinônimo de repetição, é vista por Frédéric (1985:86) como uma categoria ampla que abarca a repetição e a redundância. O termo é também definido como uma repetição de operações e até mesmo como um processo repetitivo. Nessa segunda acepção, a recorrência adquire um caráter de sobredeterminação em relação à repetição de termos (que pode ser entendida tanto como a cadeia resultante quanto como cada elemento que retoma o anterior). Ela não descreve o efeito, mas o procedimento. Em ambas as interpretações, recorrência parece inferir um universo mais amplo do que o da repetição.

Finalmente, iteração (ou reiteração) é o termo eleito por François Rastier (2009: 93), por expressar — melhor que a expressão "recorrência" — o resultado de um processo de encodagem e decodagem. O semanticista francês não evoca "repetição" como um termo possível, mantendo o seu campo de conjectura entre iteração, recorrência e redundância. Entretanto, 
aponta a mesma qualidade da iteração que consideramos central para a repetição: a ordenação. Do ponto de vista mais corrente trazido pelos dicionários, iteração é definida como sinônimo de repetição. Se há algo que é por vezes adicionado à noção de iteração é o traço de novidade, fazer novamente, renovar, o que pode até vir a ser interpretado como a não obrigatoriedade da ordenação. Por conta desses outros traços possíveis, a iteração pode contemplar nuanças que são estrangeiras ao estudo aqui proposto. Em todo caso, Rastier estava discutindo a iteração como um aspecto de um outro mecanismo: ela era o meio para se chegar ao objeto final que é a isotopia. O próximo capítulo discutirá a diferença tensiva entre isotopia e repetição e, até por isso, é bom guardar o contraste.

Uma vez bem delimitado, não nos parece haver melhor expressão para refletir a discussão proposta do que o próprio termo repetição. 
4

\section{Complexidade da Repetição}


O capítulo anterior foi o último passo no percurso de definição do nosso objeto e vimos as condições textuais para que as identidades que reconhecemos no texto sejam percebidas como repetição. Invertemos agora a perspectiva e, uma vez bem estabelecidas as condições do fenômeno, passamos a falar de seus efeitos.

Discutir efeitos é um terreno movediço e enganoso, uma vez que a interpretação é, em última instância, contingente a uma realização — se não a cada atualização ou leitura do texto. A fim de escapar dessa armadilha, buscaremos, antes de mais nada, entender a repetição como uma das estratégias possíveis para chegar a um certo efeito. Por outro lado, demonstraremos também que o efeito de que nos ocupamos é uma das funções possíveis da repetição. Inversamente, para que o estudo não se torne por demais restrito, é preciso observar ainda que não só estamos estudando um fenômeno muitíssimo vasto (a repetição), como também um efeito grandemente estruturador do conteúdo (o ritmo). A amplitude desses dois aspectos da pesquisa justifica todas as nossas tentativas de restrição, sem as quais seria impossível apreendê-los.

\subsection{Manifestante e Manifestado}

Ao discutirmos a redundância como termo vizinho à repetição na seção 3.4.2, apontamos uma diferença de níveis entre a repetição e as categorias tensivas com as quais ela parece interagir e que serão pertinentes à estruturação dos efeitos rítmicos investigados. Quando começamos a abordar a repetição, os exemplos talvez mais imediatamente acessíveis são os que 
se referem à expressão: por exemplo, as rimas em "The Raven" de Poe e do soneto de Shakespeare tratados no capítulo anterior. Poderíamos então supor uma diferença de níveis na percepção da repetição onde uma expressão constante encontra conteúdos diferentes. No entanto, os inventários do Capítulo 1 trazem exemplos de repetições de palavras, nas quais expressão e conteúdo são retomados, além de constâncias puramente de conteúdo, como é o caso da sinonímia e da repetição temática. Ainda assim, subsiste uma ideia de que a repetição manifesta algo que lhe é logicamente anterior, que ela está a serviço de um mecanismo organizador mais geral. Se não fosse assim, para que repetir?

Se voltarmos à necessidade da linearidade para o estabelecimento de uma repetição, podemos supor que a repetição não é uma relação de expressão e conteúdo, mas que tem um funcionamento semelhante, ou seja, a repetição manifesta algo mais abstrato, assim como o conteúdo é manifestado pela expressão. Assim, a oposição relevante é manifestante e manifestado: a repetição — manifestante — é uma realização possível do princípio de organização sintagmática - manifestado. Essa oposição mais geral abarca tanto a expressão quanto o conteúdo repetitivos e pressupõe a configuração de uma semiose:

a manifestação, concebida como presentificação da forma na substância, pressupõe, como condição, a semiose (ou o ato semiótico) que conjunge a forma da expressão e a do conteúdo antes mesmo, por assim dizer, de sua realização material. (Greimas \& Courtés, 2011 : 299300)

Dessa forma, a repetição é o resultado perceptivo de uma relação parti- 
cular de níveis. Trata-se da relação de uma substância manifestante e uma forma manifestada (Hjelmslev, 2010 : Def. 31 e 32), na qual a substância é percebida como repetitiva. ${ }^{1} \mathrm{O}$ termo repetição descreve, assim, tanto o efeito dessa relação quanto a sua manifestação, ou seja, a repetição é tanto o fenômeno quanto os objetos que dele resultam. É nesses termos que Molinié (1994:105 e ss.) pode falar de "efeito de repetição", como efeito de figura retórica. É também nesse sentido que poderemos dizer que a repetição manifesta outros efeitos de sentido que vão se revelar em mudanças de ritmo e andamento.

\subsection{Extremos Especulativos}

A fim de esclarecer a ligação entre a repetição, a ritmização e o andamento do conteúdo, especularemos acerca de situações limites impraticáveis, mas que revelam, por seu caráter extremo, o liame essencial entre essas três instâncias. Para isso começamos pela afirmação aparentemente simples de que as diferenças são tão essenciais à percepção de identidades quanto estas para a apreensão daquelas. Parece bastante evidente a ideia de que precisamos de uma certa constância para perceber a diferença. Num texto qualquer, se tudo com o que deparamos são diferenças, elementos novos,

\footnotetext{
${ }^{1}$ Para um outro uso - não incompatível com esse — da noção "manifestante / manifestado", ver Zilberberg (2012:31): "Recorrendo à noção hjelmsleviana de 'manifestação', a qual garante a transição entre o 'esquema' e o 'uso', diremos que a intensidade está em posição de manifestada, a extensidade em posição de manifestante." (Tradução nossa para: "En recourant à la notion hjelmslevienne de 'manifestation', laquelle [...] assure la transition entre le 'schéma' et l"usage', nous dirons que l'intensité est en position de manifestée, l'extensité en position de manifestante."). Esse paralelo vem também reforçar nossa afirmação de que a repetição pertence à dimensão da extensidade (ver seção 3.4.2 acima).
} 
somos ofuscados pela velocidade; sequer as percebemos como elementos diferentes. Diferentes do quê? A diferença passa a ser a regra e somos então lançados para fora do texto (ou dessa sequência desordenada a que talvez nem mesmo possamos chamar texto) e tomamos o todo como uno. Em outras palavras, tomamos a sequência de elementos variados como um bloco único de coisas semelhantes; semelhantes num nível superior. No final, apagamos as diferenças em favor da unidade.

Propomos um exercício que possa ilustrar essa ideia. Criemos uma sequência de imagens aleatórias apresentadas na televisão. Tentemos reunilas da maneira mais variada possível a fim de evitar qualquer categorização que as agrupasse, que trouxesse identidades e estrutura. Teríamos assim fotos realistas e desenhos abstratos, close-ups e planos de conjunto, múltiplos ângulos, imagens coloridas e em preto e branco e tudo o mais que se possa imaginar combinado de forma totalmente aleatória. Digamos então que tenhamos chegado a uma miríade de imagens tamanha que nenhum espectador pudesse encontrar aí alguma coerência e que nossa sequência fosse longa o suficiente para que as fronteiras de início e de fim também se dissipassem e deixassem de operar como elementos reguladores (possíveis igualdades). Para usar as ferramentas do capítulo anterior, seriam figuras sem fundo, o que é uma contradição de termos, visto que figura e fundo são noções que se definem mutuamente: uma não existe sem a outra. Nos quadros da semiótica, diríamos que essas imagens são por demais aceleradas e não entram no campo de presença do enunciatário.

Nosso espectador não suportaria o andamento frenético e nenhuma informação se fixaria, pois há uma necessidade de repetição para a incorpo- 
ração de novos materiais, ou seja, esperamos de nosso texto uma mínima coerência. Nesse contexto, o enunciatário terminaria por não mais ver imagens, mas sim tela. Seria tentado a passar a um plano mais amplo, onde encontraria limites, ordem, elementos de oposição e comparação que dariam sentido a essa sequência e a definiriam como imagens de televisão. Dentro dessa categoria, poderíamos, enfim, compreender o sentido do non-sense que havíamos criado.

Menos intuitiva é talvez a impossibilidade de identidades sem diferença. Parece relativamente claro que, diante de dois elementos, sabemos facilmente dizer: são iguais. No entanto, para ao menos percebê-los como dois elementos, é preciso que sejam distintos, separados por um espaço em branco ou pelo silêncio. Assim, para que sejam iguais, devem antes ser distintos. Se não houver minimamente alguma alternância, borram-se os limites e novamente, como no caso do excesso de variação, nos deparamos com um bloco unitário, com a matéria sem forma. Assim, aproximamonos da exigência saussuriana da oposição para a forma e da forma para o sentido.

Esses casos extremos aventados revelam antes de mais nada duas expectativas mínimas da interpretação. O primeiro exemplo introduz a necessidade da coerência e o segundo traz uma exigência que, neste caso extremo, se apresenta como a alternância mínima para a compreensão. Entretanto, uma vez vencida essa barreira mínima da compreensão, a alternância se manifestará numa exigência de novidade, ou seja, que algo diferente ou novo seja apresentado. Não estamos aqui confundindo a possibilidade de interpretação com o desejo romântico do original. O novo de que tratamos 
é interno ao texto, isto é, o texto deve ter direção.

Para além dessas características da interpretação, somos confrontados a questões de andamento e ritmo. No primeiro caso, temos um andamento de tal forma frenético do conteúdo que se perde qualquer possibilidade de encontrar-lhe um ritmo. Para que haja ritmo, é preciso que se estabeleçam alternâncias regulares. A mesma falta de ritmo se observa no segundo exemplo, mas por razões inversas. Ao diluirmos as fronteiras, tudo se passa como se estivéssemos o tempo inteiro frente ao mesmo objeto, como uma exposição longuíssima a um único elemento. A estaticidade total também não apresenta alternâncias e, portanto, não cria ritmo. Ambos os extremos estão contemplados na definição de ritmo do Dicionário Grove de Música: “a subdivisão de um lapso de tempo em seções perceptíveis" (Sadie, 1994 : 788). As "seções perceptíveis" são o que chamamos "alternâncias regulares" ausentes do primeiro cenário; a exigência de que essas alternâncias se desenrolem no tempo se opõe à estaticidade resultante do segundo cenário.

Assim, a estrutura é a primeira condição para o reconhecimento do ritmo. É preciso que haja identidades, diferenças e alternâncias no texto. Muito próxima da definição de repetição discutida no Capítulo 2, vemos então como interagem esses dois mecanismos. Em certa medida, podemos dizer que a repetição é uma forma de manifestação do ritmo, ou ainda, que o ritmo requer alguma repetição para se construir.

O ritmo, por sua vez, está na dependência do andamento, uma vez que este age sobre a percepção daquele: os limites máximo e mínimo do andamento apagam qualquer possibilidade de apreensão de um ritmo. Até aqui tratamos de novo vs. conhecido como a alternância geradora do ritmo 
do conteúdo, mas também o par forte vs. fraco pode estar na raiz do ritmo - via de regra, o novo é tônico e o conhecido é átono - e poderíamos dizer que é na verdade a subdimensão tensiva da tonicidade, agindo sobre a temporalidade, que estabelece o ritmo (Zilberberg, $2010: 4)$. De fato, são esses os elementos que destilamos da definição musical apresentada acima: um lapso de tempo (temporalidade) recortado em seções perceptíveis (alternantes entre tônicas e átonas). No entanto, não podemos deixar em segundo plano o papel do andamento. Vimos a sua influência nos casos limites, mas também em textos plausíveis há uma ação clara do andamento sobre a qualidade do ritmo. $\mathrm{O}$ andamento acelerado aproxima e multiplica os tempos fortes, criando um estilo rítmico entrecortado ("coupé"); por outro lado, o andamento lento escande as pausas e silêncios, revelando o liame que vai de um tempo forte ao outro, perfazendo assim um estilo rítmico corrido ("coulé") (Zilberberg, 1996:29).

Por fim, o ritmo está na dependência também do aspecto. Não poderia ser diferente, uma vez que o aspecto opera as demarcações e as segmentações do texto e, com isso, dirige o progresso discursivo (Zilberberg, 1996:26-28). A demarcação é a função aspectual que estabelece as extremidades e os limites do discurso e se manifesta em incoatividade e terminatividade: o começo e o fim. Em nosso primeiro cenário hipotético, vimos que a diferença absoluta e a velocidade paroxística lançam o sujeito para fora do texto. Este buscará o sentido não na cadeia interna — tornada inapreensível - mas nas bordas externas que fazem do caos um conjunto: imagens televisivas, neste caso. A outra função aspectual em jogo, a segmentação, estabelece limiares e intervalos. Especialmente evidente no segundo 
exemplo, a segmentação é essencial para que enxerguemos partes num todo, ou seja, para que nosso objeto não seja um contínuo indiferenciado. É porque há limiares e intervalos que podemos separar tempos fortes e fracos e, com isso, esboçar o princípio de uma ritmização.

Vemos assim que a repetição pressupõe diversos aspectos estruturais e tensivos que se organizam numa rede finamente entremeada. Assim, das oposições mais básicas — identidade, diferença, alternância — passamos pelas subdimensões tensivas — andamento, tonicidade, temporalidade e as segmentações e demarcações aspectuais para determinar o ritmo em sua relação com a repetição. Ao trazer o aspecto à baila, trazemos para a ordem do dia as relações de parte e todo, local e global e, com elas, certos regimes de progressão textual. Entretanto, resta-nos ainda alguns passos a explorar que desembocarão exatamente nessa questão.

\subsection{Repetição e Isotopia}

Usamos exemplos irreais para colocar em evidência a inescapabilidade do liame entre repetição e ritmo. Este é assim frequentemente manifestado por aquela. Uma vez que admitimos essa relação, podemos passar a examinar de que forma se dá a progressão textual por meio da repetição. Começamos então pela comparação entre ocorrências repetitivas relevantes e um outro mecanismo semiótico que guarda diversos pontos em comum com a repetição: a isotopia.

Segundo o Dicionário de Semiótica (Greimas \& Courtés, 2011 :275-276), isotopia designa: 
inicialmente a iteratividade, no decorrer de uma cadeia sintagmática, de classemas que garantem ao discurso-enunciado a homogeneidade. Segundo essa acepção, é evidente que o sintagma que reúne ao menos duas figuras sêmicas pode ser considerado como o contexto mínimo que permite estabelecer uma isotopia.

Dessa forma, o conceito de isotopia põe em jogo a semelhança entre semas e figuras, mas ao mesmo tempo cria a necessidade de que se estabeleçam diferenças entre eles. Tomemos o clássico poema de Baudelaire (1975:9-10) "L'Albatros" como exemplo:"

Souvent, pour s'amuser, les hommes d'équipage

Prennent des albatros, vastes oiseaux des mers,

Qui suivent, indolents compagnons de voyage,

Le navire glissant sur les gouffres amers.

A peine les ont-ils déposés sur les planches,

Que ces rois de l'azur, maladroits et honteux,

Laissent piteusement leurs grandes ailes blanches

Comme des avirons traîner à côté d'eux.

Ce voyageur ailé, comme il est gauche et veule!

Lui, naguère si beau, qu'il est comique et laid!

L'un agace son bec avec un brûle-gueule,

L'autre mime, en boitant, l'infirme qui volait!

Le Poète est semblable au prince des nuées

\footnotetext{
${ }^{2}$ Não vamos propor aqui uma análise desse poema tantas vezes revisitado. Trataremos apenas de uma das linhas isotópicas que colaboram na sua composição.
} 
Qui hante la tempête et se rit de l'archer;

Exilé sur le sol au milieu des huées,

Ses ailes de géant l'empêchent de marcher.

Nas duas primeiras estrofes, marcamos algumas palavras e locuções que desencadeiam uma isotopia marítima - sobretudo de uma viagem marítima. Se "les hommes d'équipage" já sugere talvez essa leitura, a ocorrência de "l'albatros" e "des mers" a confirma. A ideia de que se trata de uma viagem se faz ver apenas quando acrescentamos os verbos "suivent" e "glissant". Esses traços são importantes para contextualizar o jogo cruel dos marinheiros enfastiados que aparece na segunda e na terceira estrofe.

Esse breve exemplo nos mostra que as expressões têm algo em comum: elas oferecem uma reiteração de traços que vão reforçar uma ideia, como se remetessem todos ao mesmo lugar figurativo. Nesse processo, alguns traços que estão em potência em cada palavra são também suprimidos. É o caso, por exemplo, de tantos semas ligados à fúria do mar, à ressaca, às tempestades. Todos esses traços que poderiam desencadear uma série de lugares comuns da literatura estão aí "desativados", suspensos.

Por outro lado, é importante na isotopia que cada elemento seja também diferente um do outro. A diferença entre as expressões marcadas em nosso exemplo faz com que o cenário adquira nuanças e as imagens se enriqueçam. O texto ganha uma direção.

Entre semelhanças e diferenças, a isotopia tem um efeito extenso na composição de um sentido global, ou seja, ela é coextensiva ao texto (ou ao trecho em que a isotopia é pertinente, em textos mais longos). Podemos dizer do poema como um todo que ele gira em torno de uma isotopia 
marítima - entre outras (ver nota 2). Por meio desse mesmo mecanismo, há um efeito de caráter intenso na interpretação que se constrói para cada termo. Os termos vizinhos restringem o leque de traços estocados pelo uso à contingência desse texto, ou seja, o sentido de cada elemento parte de uma grande rede de potencialidades para ser determinado pelo contexto imediato. Assim, podemos generalizar a formulação de Claude Zilberberg (1996 : 24-26) acerca do poema "L'Eau douce" de Guillevic e dizer que o valor semiótico de um elemento é tributário de seu contexto imediato, mas também da espera que o projeta na direção dos elementos que o sucedem.

Como na isotopia, a repetição nos apresenta um encadeamento sintagmático e a posição do termo na cadeia é relevante. O primeiro termo é a apresentação do novo. O segundo é já informação dada. O segundo elemento é também o que introduz uma relação particular entre os termos. Em outras palavras, ainda que diferentes em função da sua posição, eles devem ser lidos como o retorno do mesmo. Assim, ele é também o anúncio de uma regra, de uma expectativa de repetição. Em termos semelhantes, na isotopia, o primeiro termo abre toda uma gama de possíveis caminhos. A entrada do segundo revela a relação e restringe as possibilidades.

Assim, o mecanismo sintáxico da isotopia e o da repetição parecem correr em paralelo. Como vimos no poema de Baudelaire, a isotopia é responsável pela expansão de um sentido pelo texto e, dessa forma, dá-lhe coesão. A repetição também pode ter esse papel, uma vez que por meio da iteração, ela dissemina o sentido do elemento repetido pelo texto. Podemos dizer isso, por exemplo, do retorno ao refrão em uma canção. Ele parece muitas vezes "amarrar as pontas", ou seja, atribuir coesão. Tomemos como 
exemplo um caso de repetição que não apresenta exatamente a forma de um refrão, mas que traz a cada momento à memória um certo conteúdo. Trata-se do poema “One Art” de Elizabeth Bishop (1984:178):

The art of losing isn't hard to master;

so many things seem filled with the intent

to be lost that their loss is no disaster,

Lose something every day. Accept the fluster

of lost door keys, the hour badly spent.

The art of losing isn't hard to master.

Then practice losing farther, losing faster:

places, and names, and where it was you meant

to travel. None of these will bring disaster.

I lost my mother's watch. And look! my last, or next-to-last, of three loved houses went.

The art of losing isn't hard to master.

I lost two cities, lovely ones. And, vaster, some realms I owned, two rivers, a continent. I miss them, but it wasn't a disaster.

— Even losing you (the joking voice, a gesture I love) I shan't have lied. It's evident the art of losing's not too hard to master though it may look like (Write it!) like disaster. 
Uma mesma frase é repetida em quatro das seis estrofes que compõem o poema: "a arte de perder não é difícil de dominar". ${ }^{3}$ Aquilo que devemos entender por "perda" vai mudando e se complexificando a cada estrofe com as diferentes figuras do que é deixado para trás: chaves, lugares, nomes, casas, rios, reinos e "você". Ainda assim, a frase repetida literalmente ${ }^{4}$ nos transporta de volta para o início e reúne num mesmo conjunto todas as figuras disparatadas. Uma das funções da repetição aqui é, portanto, dar coesão ao texto, organizando esse contexto como uma moldura que encerra o poema por todos os lados.

Uma outra forma de disseminar conteúdos num texto se dá por meio de explicações ou definições. Assim, se voltarmos ao texto de Baudelaire e recorrermos ao dicionário para consultar um vocábulo qualquer, teremos por exemplo: ${ }^{5}$

huée: Cris poussés par des chasseurs, des pêcheurs pour faire lever, rabattre, effrayer le gibier, le poisson.

Cris, vociférations poussés par un groupe plus ou moins important de personnes pour manifester l'hostilité ou la réprobation.

Vemos aí a apresentação de um sentido condensado em uma palavra e, em

\footnotetext{
${ }^{3} \mathrm{~A}$ tradução livre e os grifos em negrito são nossos.

${ }^{4} \mathrm{~A}$ última repetição não reproduz exatamente as anteriores. Há uma atenuação entre "não é difícil" ("isn't hard") e "não é muito difícil" ("is not too hard"). Como essa mudança não interfere em nosso argumento e uma definição de seu papel no poema exigiria uma análise mais aprofundada, não vamos estender a discussão.

${ }^{5}$ Definição do Trésor de la Langue Française informatisé (http:/ / www.cnrtl.fr/definition/). Mantivemos a definição em francês pois vamos contrastar o termo definido "huée" com as palavras usadas para sua definição. Aqui está uma tradução nossa para as duas definições: "Gritos emitidos por caçadores, pescadores para fazer levantar, abater, amedrontar a caça, o peixe." e "Gritos, vociferações emitidas por um grupo mais ou menos grande de pessoas para manifestar hostilidade ou reprovação."
} 
seguida, espraiado em um ou dois longos sintagmas. A propriedade da textualização que permite a reescritura de palavras em suas definições é a elasticidade, que faz com que denominações e definições sejam entendidas como condensações e expansões textuais, cujos sentidos são percebidos como equivalentes (Fiorin, 2014:31). Ao tratar das definições de dicionário, Hjelmslev (2003:74) aponta que os termos definidos podem ser considerados reduções dos sintagmas que os definem e propõe a seguinte formulação: "por definição entendemos uma divisão seja do conteúdo de um signo, seja da expressão de um signo."

A definição em termos de divisão indica uma espacialidade dispersa (Zilberberg, 2012:22), uma temporalidade alongada, na qual se deixam ver as etapas, e um andamento desacelerado. Assim, isotopia, repetição, definição apresentam, nesses termos, um estilo tensivo descendente (Zilberberg, $2011 b$ : 49-61). A força da surpresa, da introdução de um elemento novo no campo de presença vai diminuindo em virtude da reiteração, da repetição, da escansão desse mesmo elemento. O impacto da novidade vem a ser paulatinamente substituído pelo conforto do conhecido.

Entretanto, a repetição não é de todo semelhante aos outros mecanismos. Uma definição de dicionário que repetisse o termo a ser definido seria um dicionário ineficaz:

huée: huée

Mesmo a retomada do vocábulo em meio à explicação a tornaria confusa:

huée: Huées poussés par des chasseurs, des pêcheurs pour faire lever, rabattre, effrayer le gibier, le poisson. 
Huées poussés par un groupe plus ou moins important de personnes pour manifester l'hostilité ou la réprobation.

Nesse sentido, a repetição se distancia dos outros dois mecanismos em função do seu regime de progressão textual (Zilberberg, 1996:27). Se a isotopia apresenta uma série de semelhanças que reúnem os termos numa linha interpretativa, ela também põe em jogo as diferenças necessárias para a criação de direção no texto. Assim, o modo de progressão da isotopia é linear, ou seja, transitivo, aberto para o que vem em seguida. Num movimento relativamente semelhante, a explicação é um desdobramento de traços de início condensados, mas ela é por isso mesmo uma forma de restrição do leque de interpretações e deslizamentos de sentido que estão em potência no termo isolado. A direcionalidade e a abertura estão também presentes nesse mecanismo. A repetição, por sua vez, não produz essa direcionalidade progressiva. Para tanto, é preciso a intervenção de nuanças de diferença entre as ocorrências. A repetição é a permanência insistente num mesmo elemento; seu regime é a circularidade fechada e intransitiva que se encerra em si mesma, voltando sempre ao início. Se levada adiante, ela passará do conforto do conhecido à saturação.

\subsection{Estilo Tensivo}

Um novo estilo tensivo se anuncia na repetição: o estilo ascendente. $\mathrm{O}$ estilo descendente discutido até aqui é o resultado da apreensão de uma regra. O novo nos é apresentado, mas logo nos damos conta de que ele se repete e que continuará a se repetir de forma regular. Cada ocorrência 
é a confirmação do esperado. Não há surpresa. As retomadas são cada vez mais átonas, justamente por não trazerem nada de novo ao espírito. Entretanto, a permanência nesse estado é impraticável. A ausência total de mudança leva a uma estagnação: o texto volta sempre ao seu início e não há evolução. Há portanto uma retenção da progressão temporal, associada ao fechamento e à concentração.

Em função da natureza complexa e opositiva da linguagem, a permanência excessiva num dos polos de uma oposição gera uma expectativa de mudança (Tatit, 2007a:31-32). Em outras palavras, na teoria saussuriana, a estrutura constitutiva da linguagem se faz por oposições. Ao tratar dos princípios que regem a fonologia, Saussure (1997: 62-63) traz à baila essa relação:

A ciência dos sons não adquire valor enquanto dois ou mais elementos não se achem implicados numa relação de dependência interna; pois existe um limite para as variações de um conforme as variações do outro; somente o fato de que haja dois elementos engendra uma relação e uma regra, o que é muito diferente da simples verificação.

Ainda que o trecho aborde um aspecto específico da língua - a fonologia —, a relação diz respeito à concepção de estrutura em geral (Hjelmslev, 1991a:115-116). Dessa forma, cada elemento da língua não encontrará seu sentido ou sua função em fatores externos, mas se construirá por oposição a um outro elemento interno que lhe é comparável. Assim, se a oposição está na fundação do sistema e apenas podemos compreender um elemento por sua relação de dependência com outro, a afirmação de 
um convoca também a presença do outro. Mais ainda, os "Princípios de Fonologia" (Saussure, 1997 :49-78) propõem que um esforço continuado numa certa direção atingirá um limite: o limite da abertura vocálica é o núcleo silábico; o limite do fechamento vocálico é a fronteira silábica. Em ambos os casos, a continuidade toma a direção oposta: no auge da abertura começa o fechamento vocálico; no ponto máximo do fechamento, inicia-se a abertura. Assim sendo, mais do que uma oposição paradigmática, já temos nos "Princípios de Fonologia" um exemplo das condições de concatenação sintagmática baseada no mesmo princípio opositivo.

Esse fenômeno é, portanto, estrutural e relacional; não depende da substância manipulada. Como aponta Zilberberg (2006b:21-23), é também nos "Princípios de Fonologia" que está colocada a tese da independência da forma em relação à substância. Assim, essa saturação de um mecanismo (sons cada vez mais abertos ou sons cada vez mais fechados) leva ao limite e à inversão da direção. Se voltarmos a nosso objeto de eleição, vemos que, ao atingir um limite mínimo de tensão, a repetição sugere o seu oposto, ou seja, uma quebra do esquema repetitivo.

A repetição cria um efeito de parada na progressão textual. A permanência nesse estado seria a continuação da parada (Tatit, 2002:200-201; 2007a:54): 


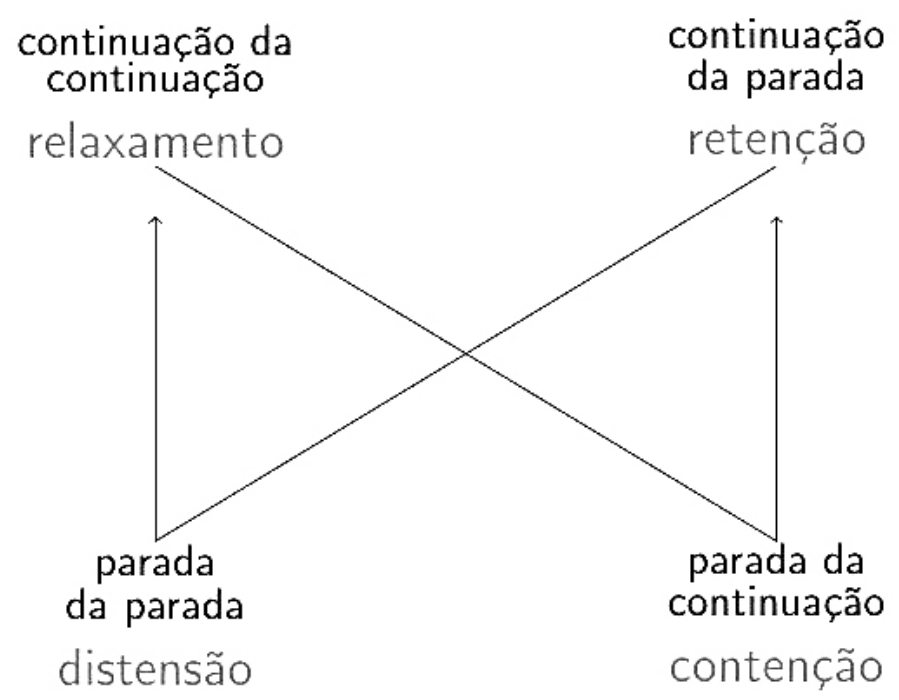

Figura 4.1 - Esquema de paradas e continuações

Do ponto de vista do desenvolvimento de um texto, a demora excessiva em qualquer uma dessas fases é inviável. Isso é bastante claro para os subcontrários desse quadrado, uma vez que são momentos de passagem. O eixo dos contrários, diferentemente, apresenta fases mais alongadas e podemos encontrar facilmente exemplos de permanência. Entretanto, justamente pelo caráter opositivo da linguagem, o alongamento em qualquer dessas fases acaba por gerar uma tensão. Ainda que se possa dizer que essa tensão está ligada às flutuações presentes no imaginário humano e que tais flutuações se manifestam nas oposições do sistema linguístico, uma vez fundado o sistema, gera-se uma necessidade interna de mudança. Um texto que se mantém sempre numa mesma fase produz um estranhamento, um mal-estar. Assim, a repetição será administrada de forma a preparar a mudança e criará uma tensão expectante de mudança. ${ }^{6}$

\footnotetext{
${ }^{6}$ A permanência excessiva numa repetição pode resultar também num estado de tédio
} 


\subsection{A Espera}

Podemos nos perguntar ainda sobre o que determina o limite da repetição tolerável. Para responder em que ponto a tensão máxima requer uma mudança, devemos recorrer às propriedades da leitura e à noção de espera. Para Octavio Paz (2012: 64):

O ritmo provoca uma espera, suscita um desejar. Se é interrompido, temos um choque. Algo se rompe. Se continua, esperamos alguma coisa que não sabemos nomear. O ritmo provoca em nós um estado de ânimo que só se acalmará quando sobrevier "alguma coisa". Ele nos deixa em atitude de espera. Sentimos que o ritmo é um ir em direção a algo, mas não sabemos o que vem a ser esse algo.

Parece um pouco contraditório que o ritmo seja circular e, ao mesmo tempo, desencadeie uma espera inquieta, que "só se acalma quando sobrevém algo". A explicação disso está nas propriedades da leitura e nas consequências da linearidade discutida no Capítulo 3. Ao iniciarmos um texto, seus elementos têm valor catafórico ou valor de chamada, convocação. Criamos hipóteses e esperas em relação ao que vai surgir. Por outro lado, nossas hipóteses podem ser confirmadas ou não e soluções inusitadas podem vir à tona. Os elementos mais tardios do texto têm valor anafórico, de retomada (Zilberberg, 1996:26). No correr do texto, podemos imagi-

e levar à "perda" do enunciatário: não há interesse, sua atenção flutua e ele se "descola" do texto. Isso se dá, em alguns casos, a partir de uma experimentação estética, mas também se o enunciatário não está bem inserido na cultura manifestada pelo texto. Em manifestações de cultura tradicional com tendência à repetição, um estrangeiro muitas vezes julgará o texto monótono. Para experimentações estéticas, ver os filmes de Abbas Kiarostami. Para manifestações culturais, ver a música e a dança Sufi, por exemplo: http:/ / www.youtube.com/watch?v=9VLEw6Ucrvw. 
nar sempre essas duas forças em jogo na interpretação de cada trecho ou até mesmo de cada signo. No trecho de Octavio Paz acima, vemos essas duas forças descritas: de um lado, o ritmo aponta numa direção que não sabemos qual é, mas ao mesmo tempo, se é interrompido, "sentimos um choque". Sendo assim, o valor da repetição na construção do impacto só será resolvido a posteriori. O dito ponto máximo de tensão só é depreendido, em última análise, uma vez a mudança ocorrida.

Também do ponto de vista de uma teoria analítica, a definição última do limite só pode ser regressiva. Da mesma forma como a leitura do texto é ao mesmo tempo progressiva e retrospectiva (Zilberberg, 2010:6), a função de suas partes depende do que lhe sucede tanto quanto do que lhe antecede. A própria segmentação é um procedimento tensivo: de um lado, propõe um primeiro programa que alinha sequências ordenadas a partir de uma origem; de outro, introduz um contraprograma de retomada, em que os lugares atribuídos inicialmente para os elementos se torna complexo e incerto (Zilberberg, 1996 : 24). No caso dos termos repetitivos, a regra implicativa pede pela continuação da repetição. A entrada do novo transforma o sentido da repetição, que passa a ser a preparação para a mudança, o caminho sem surpresas para uma virada de impacto, a calma que antecede a tempestade.

Essas observações parecem contradizer os valores átonos da espera:

os fatos que se produzem conforme o esperado são numerosos e relativamente insignificantes porque sua realização foi precedida por sua atualização, dado que, de certo modo, eles já estão aí, enquanto aqueles que se produzem contra toda espera são raros e carregados 
de sentido, levando a pensar que o número e a gravidade apresentam uma variação em razão inversa. (Zilberberg, 2010:10)

A atualização do ritmo repetitivo é a sua continuação, mas essa espera é tensa e pede mudança. A espera de uma mudança não parece diminuir o choque da mudança em si. Entramos portanto na mesma lógica das sucessões de aberturas e fechamentos proposta nos "Princípios de Fonologia": não apenas encadeamos estilos tensivos numa sintagmática do conteúdo, mas principalmente observamos como um estilo convida e mesmo exige o surgimento do outro.

É importante observar que tudo sugere que a entrada súbita de uma grandeza no campo de presença tende a ser mais impactante no grande esquema de variações de tensão. Entretanto, como vimos discutindo, textos são cadeias e o que vem antes sempre influencia o que vem depois e vice-versa. Não negamos aqui os achados de Claude Zilberberg, antes nos inserimos em seu universo para o tratamento desse tema. Também não estamos, por outro lado, medindo ou julgando quais configurações produzem maior ou menor impacto. Nossas investigações buscam tão somente avaliar a forma de construção do impacto numa das configurações textuais possíveis: na repetição.

Numa observação metateórica, é curioso refletir ainda sobre alguns escritos de Claude Zilberberg (1995; 2010:9) que apontavam a grande importância atribuída à falta e à espera na semiótica em detrimento do andamento acelerado. Desde então, o acontecimento, o sobrevir, a surpresa entraram na ordem do dia das pesquisas semióticas no Brasil e os estudos que giram em torno da falta passaram a segundo plano, talvez 
justamente porque tratam dos fatos "numerosos e relativamente insignificantes". Nossa discussão é, nesses termos, eminentemente tensiva, uma vez que estamos preocupados em estabelecer o liame entre a falta e a surpresa. A lógica da construção repetitiva é concessiva e portanto tônica: espera-se que tudo continue o mesmo, mas não continua e exatamente por isso entendemos que o mesmo era, na verdade, a preparação para o diferente.

\subsection{Local e Global}

Se, com a repetição não resolvida, estamos no máximo da espera e esta só se resolve a posteriori, vemos que há uma relação do ritmo com a globalidade. O ritmo não é mera intermitência, pois esta opera num âmbito local. Para que a repetição seja apreendida como um ritmo, é preciso compreender o conjunto das repetições tomado globalmente, ou seja, é necessário recortar o todo no qual opera a repetição:

A estruturação [do ritmo] não deve ser situada apenas no nível do esquema (abstrato), quer dizer, em relação a uma interioridade (por exemplo, para o iambo, o contraste breve-longo), sendo que uma estrutura rítmica, para que seja identificada, deve ser reconhecida entre as partes constitutivas, sucessivas, de um todo constituinte. Em outras palavras, um ritmo não é uma concatenação de esquemas contrastivos. O essencial é portanto que o esquematismo não relegue a segundo plano uma concepção gestaltista da estruturação do mesmo 
e do diferente na sucessividade. ${ }^{7}$ (Gérard, 2006:3)

É preciso a noção de acento, que é a perspectiva horizontal, mas também a perspectiva hierárquica vertical entre a parte e o todo. ${ }^{8}$

Nesse sentido, voltamos à noção de aspecto de que tratávamos acima. O componente global é estabelecido pelo recorte de extremidades e cria uma totalidade. O componente local cria intervalos e segmenta o texto em partes. Ao integrar o ritmo, a repetição requer uma noção global e outra local, de todo e de parte, para se fazer sentir. Precisamos tanto da identificação, quanto da linearidade e da saliência (ver seção 3.4.2).

Em outra escala, a repetição também age de forma intensa e/ou extensa no texto. Entendemos extenso como uma força centrífuga que espraia o sentido e é, portanto, coextensivo ao texto. Intenso, inversamente, é a força centrípeta e concentradora do partitivo, de valores expressos por uma ou mais partes (Hjelmslev, 2010 : Def. 249 e 250; Zilberberg, 1996 : 27). Assim, os recortes que estabelecem partes e todos são não somente necessários para a percepção da repetição e do ritmo em si, como também para reconhecer seu papel global no texto. De um lado, podemos ter repetições que agem

\footnotetext{
${ }^{7}$ Tradução nossa para: "La structuration ne doit pas être située au seul niveau du schéma (abstrait) c'est-à-dire par rapport à une intériorité (ex. pour l'iambe, le contraste bref-long), alors qu'une structure rythmique, pour être identifiée, doit être reconnue entre les parties constitutives, successives, d'un tout constituant. Autrement dit, un rythme n'est pas une concaténation de schémas contrastifs. L'essentiel est donc que le schématisme ne secondarise pas une conception gestaltiste de la structuration du même et du différent dans la successivité."

${ }^{8}$ Essa exigência de um componente relacional horizontal associado a um componente de análise vertical se assemelha grandemente às condições para a configuração de uma semiótica (Cf. 2.1). Por outro lado, a determinação de um texto também exige uma análise "vertical" — a paradigmática - e uma análise "horizontal" — a sintagmática (Cf. 2.1.1). A recorrência dessas duas qualidades da análise para a configuração de mecanismos e objetos distintos parece apontar para uma generalização e poderíamos nos perguntar se essa é uma exigência estrutural de todo estudo semiótico de verve hjelmsleviana.
} 
localmente para gerir o andamento de um trecho do poema. Um dos exemplos oferecidos acima que se encaixa nesse modelo é a última estrofe de "The Hollow Men" de T.S. Eliot, repetida aqui:

This is the way the world ends

This is the way the world ends

This is the way the world ends

Not with a bang but a whimper.

Apesar de a repetição estar colocada no final do poema e, com isso, ter um impacto no texto como um todo, a construção repetitiva está afetando o andamento localmente na construção da virada final. Neste caso, apresentamos apenas uma repetição local, mas podemos supor a existência de textos compostos de uma sequência de repetições independentes. ${ }^{9}$ Observamos aí uma tendência à circularidade, construída de totalizações parciais e improdutivas: anda-se em círculos.

Por outro lado, repetições de âmbito mais global amarram o andamento de todo o texto. Esse é o caso da repetição de sons [־.] e das palavras "Lenore" e "nevermore" em "The Raven". A cada estrofe que vê esses elementos repetidos, o sujeito está mais inexoravelmente preso em sua obsessão eterna. O caráter totalizante dessa repetição conhece um regime de progressão que é linear: cada repetição é mais uma volta no parafuso, ou seja, uma direção sem perspectiva imediata de fechamento. Como vimos, o texto de Poe não propõe uma solução para a angústia do ator do enunciado. Uma vez que tal fechamento só ocorre ao final do texto

\footnotetext{
${ }^{9}$ Atestaremos esse caso com a reprodução de mais estrofes de "The Hollow Men" ao final do próximo capítulo.
} 
(se ocorrer), as sucessões do texto são sentidas como dirigidas, transitivas. Talvez seja estranho imaginar que a repetição possa ser linear, mas se nossa argumentação até aqui se sustenta, a repetição dirige a percepção e, paradoxalmente, ${ }^{10}$ não ir a lugar nenhum é também uma direção do sentir para o enunciatário.

Por fim, podemos ainda aventar o estilo misto ou híbrido de uma progressão em espiral, "ao mesmo tempo circular e linear" (Zilberberg, 1996:28-29). Nesse caso, a progressão se dá por ciclos que se sobrepõem, fazendo com que em parte retomem e em parte avancem os conteúdos trabalhados. Um exemplo do estilo espiral está representado na estrutura das repetições nos "Poema(s) da Cabra" de João Cabral de Melo Neto, analisado no próximo capítulo.

Neste capítulo, abordamos a delicada noção de que a repetição possa ter um efeito no arranjo tensivo do texto. Dizemos que é delicada porque a própria ideia de estudar efeitos é fluida e frequentemente contingente ao ato de leitura. Assim, preferimos falar da repetição como uma manifestação possível da trama tensiva do texto. Abordamos então a repetição em estilos tensivos descendente e ascendente, na progressão textual circular, linear e espiral e, com isso, entramos em detalhes da construção da espera e do papel fundamental do aspecto para a gerência da repetição. Por todo o capítulo usamos exemplos de repetição para explorar as diferentes facetas do fenômeno. No próximo capítulo, invertemos a perspectiva e, ao invés

\footnotetext{
${ }^{10}$ Essa ideia é paradoxal para o senso comum. Como discutido acima, toda a teoria saussuriana é baseada em opostos complementares e suas alternâncias.
} 
de extrair a repetição relevante, vamos mantê-la no texto integral e com isso explorar de que forma ela se insere na interpretação global do texto. 


\section{Análises}

\section{Contraste entre Local e Global}

Porque o único sentido oculto das cousas

É elas não terem sentido oculto nenhum,

É mais estranho do que todas as estranhezas

E do que o sonho de todos os poetas

E os pensamentos de todos os filósofos,

Que as cousas sejam realmente o que parecem ser

E não haja nada que compreender.

Alberto Caeiro 


\section{ANÁLISES}

CONTRASTE ENTRE LOCAL E GLOBAL

As análises apresentadas neste capítulo são menos uma ilustração da discussão empreendida no último capítulo, do que sua extensão. Aliás, a nosso ver, é essa a função das aplicações: confrontar-nos com os limites e extensões de nosso corpo teórico. Nesse sentido, apresentam exemplos particulares e mais orgânicos de repetições no texto, inseridos na análise global dos objetos, com sua direção própria, isto é, não a serviço direto da argumentação da tese. Nesses termos, podemos observar a maneira como a repetição interage com os demais aspectos da análise e, assim, melhor entender o lugar e o uso da repetição nos textos.

A primeira análise discute um poema do João Cabral. $\mathrm{O}$ aspecto repetitivo se constrói em espiral, no sentido de que palavras aparecem paulatinamente no texto, reiteram-se e desaparecem, abrindo lugar para novas repetições, de forma a enriquecer sempre a palavra-chave: "cabra". Estabelece-se, assim, um laço interessante entre a ação local e global da repetição no texto.

A segunda é a análise de uma canção de Cole Porter, interpretada por Ella Fitzgerald. Há uma frase que se repete ao longo do texto, mas sua interpretação muda à medida que a história avança. Esse estudo contribui para a discussão da repetição como estratégia global e, portanto, para a manifestação de uma linearidade nesse objeto tão circular que é a repetição. 


\subsection{Poesia - A Desconstrução de um Objeto em}

\section{Valor}

Nos “Poema(s) da Cabra” (Anexo I), João Cabral de Melo Neto (1997: 239_

245) toma a figura desse animal ao mesmo tempo nordestino e mediterrâneo como seu objeto de trabalho. À cabra vai somando qualificações, habilidades, potências. Entretanto, ao acrescentar-lhe tanto, o que antes poderia ser um símbolo - alguma materialidade que remete a ideias - , começa a se tornar apenas qualidade. A cabra passa de objeto de estudo a valor último imbuído no homem do Sertão.

Para construir esse percurso, João Cabral vai usar de alguns recursos já bastante reconhecidos em sua poética, como o tom, a forma, a rima, o vocabulário. Vamos, então, analisar cada um desses componentes, além de alguns outros não tão frequentemente mencionados, mostrando de que forma estão imbricados nessa estrutura construída pelo poeta e como operam para criar o efeito sugerido de um objeto transformado em puro valor.

\subsubsection{O Tom e o Gênero}

Os "Poema(s) da Cabra" são divididos em onze partes, das quais nove são numeradas e formam o centro do poema. Além dessas nove partes, há uma introdução e um epílogo não numerados. O poema, com o distanciamento típico de João Cabral de Melo Neto (Nunes, 1971:63), cria uma espécie de tratado ou estudo da cabra, que acaba por se revelar num tema caro ao 
poeta: a condição do homem do Sertão.

O tom geral da peça é mesmo quase o de um tratado e está aí a primeira presença estruturante da repetição no poema. Diversos elementos da estrutura sintática, da escolha de vocabulário e da forma da expressão contribuem para esse tom. Primeiramente, observamos uma estrutura sintática repetitiva com amplo uso de cópula, como se o enunciador estivesse todo tempo encadeando definições: isso é aquilo, se " $a$ " é " $b$ ", então "c" é "d", e assim em diante. As sentenças do texto tomam, assim, uma forma proposicional. Os versos curtos, trazendo definições conceituais e associando clara e diretamente sujeitos e predicados, lembram premissas de silogismo.

No vocabulário, percebemos uma estratégia bastante reconhecida na obra cabralina, que é a escolha por uns poucos itens lexicais que vão sendo repetidos exaustivamente (Villaça, 2003:147-148; Barbosa, 1974: 148 e 2005 : 122 e 129). ${ }^{1}$ No interior de "Poema(s) da Cabra", as repetições vão contribuir para a construção desse simulacro de texto "científico". Como veremos em mais detalhes no decorrer da análise, a cabra pouco a pouco passará de um objeto (ou entidade) a uma qualidade. A repetição traz o eco de texto científico, na medida em que, nesse gênero de texto, certos itens lexicais formam uma metalinguagem específica, e devem ser sempre repetidos sem lançar mão de sinônimos, para a construção do sentido "justo" das palavras. Também assim, no poema de João Cabral, a "cabra", a "pedra", o "osso" ganham sentido preciso, quase como uma "metalinguagem" cabralina.

\footnotetext{
${ }^{1}$ Para um exemplo desse procedimento de João Cabral, conferir a repetição das palavras "caminho", "cana", "encontrar" no trecho "Do Petricu ao Taparucá" do poema "O Rio" (Melo Neto, 1997: 100).
} 
Por fim, como que para garantir o tom, encontramos elementos de expressão muito rígidos: todas as partes têm quatro estrofes; cada estrofe, quatro versos; todos os versos, oito sílabas; as rimas toantes sempre nos segundo e quarto versos de cada estrofe; cada estrofe sempre com uma e apenas uma expressão em itálico (voltaremos a isso). A forma constante espelha a sintaxe simétrica e o vocabulário repetitivo. Dissemos que essas estratégias são muito frequentemente encontradas no verso de João Cabral, mas, para além das idiossincrasias do autor, esses elementos geram um efeito no texto em estudo: reforçam o simulacro de texto científico que despontava no desenvolvimento do tema, nessa construção da qualidade do nordestino.

Cada uma das nove partes centrais numeradas que formam os "Poema(s) da Cabra" traz o seu tema geral condensado numa figura marcada no texto por letras em itálico: (i) mais barato; (ii) negro de vida; (iii) apenas côdea; ${ }^{2}$ (iv) o inconformado conformista; (v) parte com o Diabo; (vi) capaz de pedra; (vii) jamais contemplativa; (viii) mesma casta; (ix) o aço do osso. Mais uma vez, a combinação de um elemento gráfico e seu sentido na economia do texto reforçam o tom do poema. A elasticidade do discurso apresentada na condensação de uma expressão, em oposição ao desenvolvimento do tema que se observa pelas quatro estrofes da parte em que a expressão está inserida, traz novamente à baila o formato argumentativo do texto: como se fizesse uma análise (nas estrofes) e em seguida sua síntese (na expressão que, quase sempre, fecha a parte). Note-se como, por exemplo, mais barato

\footnotetext{
${ }^{2}$ Côdea: espécie de crosta externa dura - pode ser casca de pão, pode ser crosta de sujeira.
} 
condensa a ideia que vai se formando desde a primeira estrofe dessa parte. Reitera-se, por toda essa Parte Um, a qualidade "inferior" do negro da cabra. De início, nega-se a riqueza na primeira estrofe. Em seguida, são usados adjetivos que qualificam seu preto como "pouco", "cinzento", mas também como "pobre". Na terceira estrofe, é descrito como um preto que "perdeu toda cor no gasto". Vão, assim, se reiterando semas de pobreza e falta de brilho. Esses semas se veem espelhados na escolha do elemento em negrito: mais barato.

Todos esses elementos repetitivos são estruturantes do texto, mas não interferem muito nas modulações tensivas variáveis no texto, nos moldes tratados no Capítulo 4. Sua função se assemelha talvez mais ao papel da rima no poema de Shakespeare, mencionado no Capítulo 3. Ademais, outros aspectos da construção do poema, não especialmente ligados à repetição, contribuem para o tom geral. Como um tratado - e isso é comum em quase todo poema de João Cabral —, há um distanciamento entre a instância da enunciação e aquilo que vem sendo tratado no texto. $\mathrm{O}$ texto é todo construído no registro enuncivo. Mais que isso, as escolhas de ancoragem de tempo e espaço revelam um tempo alongado e um espaço amplificado.

No espaço, vemos regiões amplas, maior que a escala humana. Quando são mencionados muros, cercas, caatinga, esses poderiam estar em qualquer parte do Sertão. São lugares estereotipados que trazem uma ideia de repetição, de uma condição universal do Sertão nordestino. Ademais, os lugares mais específicos mencionados estão deslocados do centro "argumentativo" do poema. É exatamente na introdução e no epílogo que 
estão esses elementos de localização espacial como o Moxotó, o Pajeú e o próprio Mediterrâneo. Essas partes, inicial e final, são diferentes em diversos pontos. Para começar, elas estão entre parênteses, como se destacadas do conjunto. Não estão numeradas e trazem os topônimos mais específicos, como acabamos de mencionar. ${ }^{3}$ Além disso, no epílogo, surge o único trecho de debreagem enunciativa, numa explicação: “Em nada me lembra..." e "não minto".

No tempo, há o predomínio do presente gnômico, outro construtor de generalizações. Não há momentos pontuais no texto. As ações correspondem a funções descritivas como: "cabra cava raízes" ou "nordestino desconfia de cabra". Há uma referência a uma temporalização no passado nas menções ao Mediterrâneo, ao mármore, ao "mar clássico", ao "ébano douto". Esse tempo é sempre associado ao espaço do Mediterrâneo, mas veremos que a imutabilidade instaurada na figura de um tempo clássico é um traço que também será reconhecido no Sertão, dado que a condição do nordestino está arraigada no "aço do osso".

O presente gnômico, a ideia de imutabilidade e o largo uso de descrições garantem uma estaticidade ao texto. A cabra aparece, então, como um elemento de dinamicidade, de transformação, ainda que, no poema, surja localizada no passado, como mudança já operada. Vemos, especialmente nas partes Oito e Nove, o uso do pretérito perfeito em verbos que sugerem a transformação do homem e do jumento por incorporarem as qualidades

\footnotetext{
${ }^{3}$ Usamos a edição da Nova Fronteira de 1997. Outras edições do poema trazem diferentes formas de marcação da parte inicial e da parte final. Ainda assim, permanece o fato de que essas partes estão diferentemente destacadas de tal forma que ficam ressaltadas do conjunto.
} 
da cabra. Assim, temos:

Os jumentos são animais

que muito aprenderam com a cabra.

O nordestino, convivendo-a,

fez-se de sua mesma casta.

$[\ldots]$

A cabra deu ao nordestino

esse esqueleto mais de dentro:

(Melo Neto (1997: 244). Grifos nossos.)

\subsubsection{A Progressiva Aproximação}

As partes Oito e Nove trazem também uma virada no poema: de objeto descrito a cabra passa a trazer as qualidades que se entreveem no homem. No entanto, o poeta não diz apenas que o nordestino é forte, duro ou resiliente, mas constrói, para dizê-lo, um novo "adjetivo", uma qualidade de cabra.

Por meio de estratégias de exacerbação, o poeta faz da cabra uma qualidade mais forte que o forte, mais dura que o duro. Daí termos a justificativa do epílogo que garante que a cabra do "nobre" Mediterrâneo é a mesma do Moxotó. ${ }^{4}$ Trata-se da mesma cabra, pois é, na verdade, uma essência

\footnotetext{
${ }^{4}$ Essa traduzibilidade de figuras do Nordeste e do Mediterrâneo (em geral da Espanha) foi reconhecida como uma estratégia em vários poemas de Cabral desde o livro Paisagens com Figuras, anterior a Quaderna, de que o "Poema(s) da Cabra" faz parte (Melo Neto, 1997). Cf. Barbosa (2005: 120 e 124). Neste artigo, procuramos localizar que papel essa correspondência de figuras desempenha na economia deste poema em particular.
} 
da cabra, uma figura da inerência, que portanto está presente de forma genérica em todas as cabras. Se, a partir dessa virada, retraçarmos nossos passos, lendo de baixo para cima, vemos que o tema do Nordeste já estava colocado desde antes. Na Parte Nove, vemos a cabra como parte do nordestino, o seu núcleo; ela está dentro do homem; é o "aço do osso". Na oitava parte, a cabra e o nordestino são um; são da "mesma casta". Numa e noutra parte, constrói-se o ser da cabra. Na sétima parte, a cabra está ligada à lavoura do Sertão em figuras como "desenterrar raízes" e "mãos ásperas" do trabalho com a terra e, portanto, vemos o fazer do animal. Na Parte Seis, a cabra está livre para circular na caatinga, ao mesmo tempo que presa a ela. Trata-se do seu estar. Sua condição é como a do sertanejo. Na parte de número cinco, a cabra é tratada como um instrumento do homem, um instrumento de lidar com a terra e, nesse momento, instaura-se o elemento narrativo talvez mais crucial na transposição para o nível figurativo, que é o poder da cabra. Esse poder da cabra pode ser visto, por exemplo, na última estrofe da quinta parte:

Por isso quem vive da cabra e não é capaz de seu braço desconfia sempre da cabra: diz que tem parte com o Diabo. (Melo Neto, 1997: 242)

A primeira associação das qualidades da cabra ao homem, em especial de seu poder, está aí expressa. Esse trecho nos remete ao uso comum da designação cabra para se referir ao homem do Nordeste; inclusive à forma cabra macho, que diz respeito à coragem e força do sertanejo. Vemos assim 
que, em todos esses momentos, a figura do sertanejo já está presente por meio de figuras metonímicas: suas mãos, seu lugar, seu trabalho.

Voltamos, então, a ler o poema do começo ao fim e percebemos que, ao lado dessas figuras do Sertão, para a incorporação dessa qualidade de cabra ao nordestino, foi sendo construída uma aproximação gradativa do sujeito. Dissemos, no início, que o texto se construía à distância do sujeito da enunciação. Esta se mantém. A aproximação a que nos referimos é de um sujeito do enunciado. Aos poucos, o poema vai caminhando na direção de uma escala humana. Não estamos aqui tratando exatamente de uma aproximação espacial, ainda que ela também possa ser percebida. Trata-se, mais precisamente de um fechamento figural (Zilberberg, 1986; $2006 b$ :109-110). Em outros termos, nas primeiras partes, temos figuras abstratas ou gerais, portanto distantes, como as cores (Parte Um: negro, branco, pardo), como o dia, a noite, o luto, o mistério (Parte Dois). Na terceira parte, já há elementos próximos à cabra como a terra e a pedra e começa-se a trazer elementos do corpo: lábios, moela. Na quarta parte, temos uma comparação com os outros animais e entra aí a figura do homem. Daí em diante, podemos seguir os elementos comentados acima: a cabra vai se tornando o homem, pois passa por seu instrumento (Parte Cinco), vive onde o homem vive (Parte Seis), cultiva a lavoura como o homem (Parte Sete), até ser comparável ao homem, de mesma casta (Parte Oito). Por fim, a cabra "entra" no homem e é sua essência (Parte Nove). 


\subsubsection{O Tratamento das Figuras}

\section{O Clássico e o Sertão}

Ao opor a figura do Mediterrâneo à do Sertão, o texto engendra uma série de efeitos de sentido. O primeiro deles é justamente a criação de uma temporalidade, ainda que bastante alusiva, na ideia de que o Mediterrâneo remete a tempos passados, clássicos e nobres. Daí que a primeira parte se inicia numa explicação de que o negro da cabra é diferente do "negro douto do ébano". Justamente a partir dos sentidos solenes trazidos na introdução pela referência ao lugar que chamamos "berço da civilização ocidental", é que João Cabral vai começar a traçar as oposições que vão configurar essa qualidade de cabra.

Aos poucos, vai se associando ao mar europeu um andamento desacelerado, marcado na escansão do tempo. Esse andamento lento está ligado às próprias ideias de Antiguidade e do Classicismo, mas também está marcado na oposição ao Sertão, caracterizado, como veremos, por um andamento mais acelerado: este deixa-se ver no trabalho constante, na lida com a terra seca. A cabra deve "cavar", "desentranhar raízes", "verrumar a terra magra", sem ser "jamais contemplativa".

Por fim, essa temporalidade que dissemos estar associada ao Mediterrâneo se revela imutável, uma vez que seus valores perduram no tempo. Essa imutabilidade aparece expressa, por exemplo, na fixidez das ondas do mar que "estão no mármore traçadas" (segunda estrofe do epílogo). Entretanto, nesses termos, o Sertão também é imutável e está aí o ponto de aproximação que permeia o epílogo. A própria escassez de marcas temporais do texto já 
produz um efeito de alargamento do tempo, no sentido da construção de uma verdade atemporal. Mais de perto, vemos que o tratamento de temas abstratos nas primeiras estrofes também tem esse mesmo caráter, uma vez que não determinar um tempo é o mesmo que dizer que se fala de todos os tempos.

Nas estrofes em que se vai aproximando da cabra, revela-se pouco a pouco certo fatalismo. Por exemplo, na sexta parte, temos uma cabra "condenada à caatinga". Nas últimas partes, como a cabra passou a uma qualidade, ela ocupa o espaço interior: “O núcleo de cabra é visível / por debaixo de muitas coisas". Há uma ideia de essência, de algo que faz parte constitutiva do homem em figuras como: "esse esqueleto mais de dentro", "o fundo centro de seus ossos" ou "o aço do osso, que resiste / quando o osso perde o seu cimento." Esse fatalismo e essa interioridade, que são traços associados aos homens do Nordeste, trazem consigo o mesmo sema de imutabilidade que víamos, por razões distintas, nos valores associados ao período clássico. Se no início do texto vai se traçando uma separação entre os valores do Mediterrâneo e os do Sertão, o epílogo retoma e reaproxima os dois lugares, tornando um e outro atemporais.

\section{Espaços Opostos}

Outras oposições criadas pelo autor são da ordem da espacialidade. Vemos associados à figura da cabra dois termos opostos, fazendo desse animal um termo complexo. Dessa forma, faz-se presente a horizontalidade nas figuras da "caatinga", do animal "ambulante", do "vasto sem nada", como aparece na Parte Seis, como também, logo em seguida na Parte Sete, a verticalidade 
está marcada em termos como a "pendente", o "cavar" e a "vida sob a superfície". Esse traço, em particular, remete à figurativização da cabra na iconografia medieval, em que o capricórnio é considerado industrioso e vencedor, bem como traz uma dimensão vertical em sua figura. Sua metade traseira é a de um peixe, profundo portanto, e sua metade dianteira é a cabra, o animal terrestre que alcança as maiores alturas.

Também os opostos "dentro e fora" na Parte Seis contribuem para a configuração da cabra como elemento complexo. ${ }^{5}$ Vemos, assim, figuras da cabra" trancada do lado de fora", mas que também é "trancada por dentro". Ela está ainda tanto dentro quanto fora, pois é "ambulante prisioneira", ou ainda, "prisioneira e carcereira". Veremos, a seguir, que essa elaboração paroxística da figura da cabra pela convergência de contrários encontrará eco nas construções concessivas da forma de argumentação do poeta.

\section{Construção Concessiva}

Um outro traço da construção da figura da cabra que se sobressai na argumentação do poeta é a forma concessiva da apresentação dos contrastes. Nas primeiras partes está o contraste entre aquilo que diz e aquilo que não diz respeito à cabra, ou seja, a argumentação por contrastes fortes, por vezes beirando o oxímoro, como em: "Negro do feio, às vezes branco" (Parte Um) ou "o reduzido irredutível, / o inconformado conformista" (Parte Quatro). À medida que avançam as estrofes, vai-se criando uma nova

\footnotetext{
${ }^{5}$ Curioso notar que, a respeito de Uma Faca só Lâmina, Barbosa (2005:122) vai comentar que vários termos na poesia de Cabral vão se substituindo para que se atinja o âmago da imagem: só lâmina. A mesma busca da essencialidade parece se operar aqui, mas esse centro da imagem é de uma essência complexa, totalizante.
} 
forma de argumentação em que o enunciador cria um limite numa escala tácita. Para ele, então, a cabra vai estar além desse limite determinado. Como exemplo, começamos no registro da morte, que está sempre presente, como na sexta parte, em figuras como "caatinga seca", "vasto sem nada", "fome e sede". Dentro desse paradigma, aparece, na Parte Sete, a figura do urubu à procura de carniça. Em seguida a essa imagem, a vida da cabra é apresentada como sem espaço para lazer. Ora, por contraste, é como se o autor estivesse dizendo que a procura do urubu por carniça fosse um lazer perto da castigada vida da cabra. $\mathrm{O}$ urubu, que era o fim da cadeia alimentar, daquele a quem só cabem os restos da ceia de um outro, não é ainda o limite, pois ainda há a cabra. Uma outra figura de máxima resiliência no contexto sertanejo é o jumento. No entanto, na Parte Oito, está dito que toda essa força e resistência foi aprendida - da cabra.

Essa construção de traços hiperbólicos é concessiva, na medida em que ao enunciatário é dado um limite e, portanto, uma expectativa de fim. Entretanto, aquilo que lhe vem em seguida é o recrudescimento do que já tinha chegado ao extremo, é o só mais (Zilberberg, 2011b: 55-56).

\subsubsection{Estrutura Involutiva}

A escolha vocabular repetitiva e as recorrências sintáticas guardam mais um valor no conjunto, que contribuirá para o desenvolvimento do sentido global que constrói a cabra como figura da resistência sertaneja, bem como da amarração formal dos elementos envolvidos nessa construção. Esses dois mecanismos - repetição de palavras e de formas sintáticas - têm 
um efeito no ritmo global do texto. A insistência, numa determinada parte, num grupo de vocábulos, garante uma permanência rítmica, um vai-e-vem entre os mesmos elementos, que produz uma resistência à evolução do texto. Assim, na Parte Dois, por exemplo, temos uma reiteração do claro e do escuro, da vida e da morte: semas que se repetem exaustivamente nos vocábulos.

\begin{tabular}{cc}
\hline CLARO & ESCURO \\
\hline $\begin{array}{c}\text { sol, solar, } \\
\text { luminar, queimado }\end{array}$ & $\begin{array}{c}\text { escuridão, noturno, noite, } \\
\text { carvão, coque, hulha, pólvora }\end{array}$ \\
\hline \hline VIDA & MORTE \\
\hline sol, vida & funeral, luto, morte \\
\hline
\end{tabular}

A sintaxe, por ser igualmente repetitiva, também retém o texto, sem deixá-lo progredir.

Uma vez terminada a Parte em questão, o texto, naturalmente, volta a caminhar quando da passagem para a Parte seguinte. Dito dessa forma, temos a impressão de que o texto progride em ciclos sucessivos, em que cada parte forma um ciclo. O mecanismo é, entretanto, um pouco mais elaborado. Nessa mudança progressiva, alguns elementos se mantêm, mas outros são deixados para trás e novas palavras são introduzidas. Note-se que a palavra "negro" e os vocábulos que se referem aos mesmos semas vêm sendo repetidos desde a Parte Um. Eles se mantêm nas Partes Dois e Três, mas na Parte Quatro já não estão mais. Entretanto, não é apenas a escolha vocabular que vai mudando: os sentidos convocados vão evoluindo 
paulatinamente. Escolhemos uma das linhas de evolução do texto como exemplo dessa progressão na expressão e no conteúdo.

Logo na parte introdutória do poema, somos apresentados à ideia de que a terra foi tornada pedra e que esta é ocupada pela cabra. A Primeira e Segunda Partes abandonam essas noções para tratar do negro pobre, sujo e de pouca qualidade da cabra. A Parte Três ainda menciona o negro, porém já menos vezes do que antes (a palavra aparece quinze vezes na Parte Dois e apenas cinco, na parte Três). O que se introduz agora são as palavras "raiz", "duro" e "fundo" associadas ao negro e à pedra, retomada da parte introdutória. Em contraposição, somos também apresentados a tudo o que a cabra não é: orvalho, folhas, moelas, úmidos e lábios. A pedra continua a ser apresentada aqui e ali e, na Sexta Parte, aparece novamente contrastando com folha e verde. Na Parte Sete, já não mais aparece a palavra "pedra"; também não encontramos a palavra "duro" ou "fundo". Esses sentidos estão, no entanto, presentes em algumas palavras repetidas (proibida de folhas, desentranhar raízes) e outras novas que vêm deslocar parcialmente o sentido primeiro. Assim, se "o negro é o duro que há no fundo da cabra", agora é abordado um sentido mais literal — ou ao menos figurativamente externo à cabra: "cavar a vida sob a superfície", "grosseira, de mãos ásperas". A Oitava Parte retoma o caráter de essência que tinha a palavra "fundo" na Parte Três, mas usa para isso o vocábulo "núcleo" e combina o caráter externo à cabra da Parte Sete com essa noção profunda: "o núcleo de cabra é visível”, crosta, couro, sola, couraças, escamas. Por fim, a Parte Nove continua a tratar do núcleo e retoma o fundo, acrescentandolhe o centro. Essa essência dura sugerida na figura da pedra do início do 
poema se torna nervo, ossatura, esqueleto e acaba como "o aço do osso". Propomos um breve levantamento da presença dessas palavras em algumas das partes:

\begin{tabular}{ll}
\hline Parte & Palavras \\
\hline \hline Introdução & Mediterrâneo, terra, pedra, fera \\
\hline Um & negro, preto, pobre \\
\hline Dois & negro, queimado, carvão \\
\hline Três & negro, duro, fundo, pedra \\
\hline Quatro & arisco, rebelde, selvagem \\
\hline Cinco & terra, pedra, dura \\
\hline Seis & pedra, folha, seca \\
\hline Sete & cavar, superfície, folha, raíz \\
\hline Oito & núcleo, visível, crosta, couro \\
\hline Nove & núcleo, fundo, aço, osso \\
\hline Conclusão & Mediterrâneo, Sertão, terras, negras \\
\hline
\end{tabular}

Fica claro pelo quadro que há uma certa circularidade global, não apenas porque o vocábulo cabra se repete em todas as partes, mas também pelo retorno da menção ao Mediterrâneo, que fora abandonado na própria introdução. No entanto, ao lado disso, vemos uma clara progressão que vai pouco a pouco introduzindo, repetindo e abandonando palavras. Tudo se passa como se o poeta destilasse um sentido até que esteja bem integrado no que devemos entender por cabra. Uma vez o sentido incorporado, pode passar para um próximo. A mudança não é súbita. A Parte Três é exemplar: 
ao mesmo tempo em que apresenta as últimas repetições de negro, introduz as noções de fundo e duro que começam a ser exploradas nessa parte e nas que se seguem.

A combinação da repetição circular com a progressão linear cria um modo espiral de progressão textual (Zilberberg, 1996:27-29). Esse mecanismo parece reforçar o sentido até que a cabra - único item que se mantém por todo o texto - esteja, por assim dizer, impregnada daqueles valores. Estamos aí mais uma vez construindo esse núcleo de cabra que será figura especialmente intensa ao cabo do poema.

A sintaxe parece usar da mesma estratégia, talvez com ainda menos variações. As Partes Um, Dois e Três apresentavam apenas sentenças assertivas, com o verbo ser e formas genitivas com a preposição de. Na Parte Quatro, são introduzidas perguntas e novos verbos, apenas para depois cair novamente nas orações com a cópula. E assim, segue num vai-e-vem entre repetições de um tipo e de outro que vão montando um fluxo, um ritmo talvez mais global no poema do que o trabalho local do vocabulário.

Essa estrutura rítmica dos elementos lexicais, em especial, é semelhante àquela da canção popular desenvolvida por Luiz Tatit (1997: 22 e ss.). O autor observa que há um processo de concentração na repetição constante de certos trechos da melodia, que evita que a melodia se desenvolva, ou evolua com direção. É como se a canção estivesse a todo tempo se revolvendo sobre si mesma. Transposto esse mecanismo para o componente verbal, os sentidos reiterados insistentemente nos itens lexicais criam uma concentração no plano do conteúdo, levando ao que Tatit chama de involução. 
Os progressos se darão de maneira gradual, na forma de desdobramentos. A canção que oscila entre as tematizações (essas repetições locais) e os desdobramentos está no registro da concentração de ordem intensa. Essa dinâmica de tematizações e desdobramentos articula o mesmo tipo de progresso paulatino. A ênfase, no modelo de Tatit, está mais claramente no fechamento involutivo do que na organicidade da passagem de uma repetição a outra, sugerida pela expressão "espiral". O essencial é que o poema de Cabral evolui lentamente por desenvolvimentos locais, numa alta concentração de sentido. Assim, esse mecanismo "musical" contribui mais uma vez para a intensidade de sentido com que é construída a figura da cabra.

Iniciamos este estudo pela observação de que a estrutura dos "Poema(s) da Cabra" lembrava francamente a de um tratado. Levantamos então uma série de elementos formais que faziam construir esse simulacro de um poema-tratado. Nesse sentido, observamos uma série de elementos da expressão, assim como o uso de construções abstratas, aparência de silogismos e formas proposicionais. Observamos recursos retóricos na elaboração argumentativa: oxímoros, construções hiperbólicas, argumentações concessivas. Por fim, estudamos o caminho rítmico traçado pela repetição do conteúdo lexical e sintático. Todos esses elementos, além de conduzir o tom, levavam também a argumentação numa certa direção: o texto de João Cabral traça o caminho do geral para o particular e de volta ao geral. Se de início aparecem qualidades atribuídas por itens lexicais gerais 
ou por demais distanciados do objeto em descrição - a cabra -, num segundo momento, passa-se à aproximação do objeto por meio de uma descrição estereotipada nos topoi da vida árida do Sertão. Se, então, víamos uma tendência à aproximação e à particularização, não é exatamente nessa direção que segue o texto. Mais uma vez caminhando para o sobrevir, para o inesperado, o poeta passa a uma dimensão abstrata, mas, dessa vez, traz consigo a cabra, que vinha tão hiperbólica e contrastivamente sendo construída. A cabra do poema deixa de ser um animal e passa a ser uma qualidade - não se fala mais da cabra, mas do núcleo de cabra. Como sugere o título deste estudo, a cabra deixa de ser um objeto para buscar ser só valor. Há, sim, uma continuação na direção de uma aproximação, mas porque essa cabra-qualidade passa a ser interior, compondo o centro mesmo do homem nordestino. 


\subsection{Canção - Estudo das Emoções na Letra, na Música e na Voz}

A canção "Miss Otis Regrets", de Cole Porter, nos apresenta o percurso passional de uma mulher. Dizemos conhecer as flutuações de seus estados de alma, mas, em verdade, apenas nos é relatada a sequência de eventos que desembocará em sua morte. Por conta disso, é muito difícil, em cada sequência da letra, nomear a paixão que está sendo mobilizada. Ainda assim, resta uma impressão geral de que conhecemos os sofrimentos de Miss Otis.

$\mathrm{Na}$ realidade, conhecemos a história por meio do relato de um(a) criado(a), que foi incumbido(a) - não sabemos detalhes dessa determinação - de avisar uma outra pessoa da ausência de Miss Otis num compromisso. É nessa instância, na relação do narrador com o narrado, que aprenderemos não apenas o desenrolar da ação, mas também como interpretar as mobilizações passionais. Essa relação, entretanto, não é banal. Como dissemos, não é simples nomear as variações passionais. Elas são mais aludidas do que ditas e é também nesse ponto que axiologias são apresentadas e negadas.

Assim, propomos, neste estudo, a investigação da relação narradornarrado, tida como lugar de eleição do enunciador para a manipulação de tensões desse texto. A relação gira, nessa peça, em torno de uma mesma frase que se repete. A repetição recebe uso particular nessa dinâmica: sua interpretação sofre alterações importantes a cada parte do relato que se apresenta, chegando a mudar a referência apreendida. Em outras palavras, a cada repetição, imaginamos um cenário diferente descrito pela frase. 
Para analisar a mediação entre a narração e os valores apreendidos na enunciação, dividiremos as partes do texto, traçando uma relação com sua organização musical. Em seguida, investigaremos o percurso passional de Miss Otis por meio do encadeamento narrativo e das figuras que dão pistas dos estados de alma da protagonista. Por fim, estabeleceremos as diferenças entre o narrado e a narração e as formas como estão simbioticamente entrelaçados na construção do sentido global do texto.

\subsubsection{Organização Textual}

Para chegar ao papel do narrador, traçaremos antes um quadro do relato que nos é apresentado. Nosso foco é a depreensão da caracterização passional da personagem Miss Otis, a construção da axiologia do texto e a mediação do narrador. Portanto, o centro da análise é o componente verbal. Entretanto, é inegável que a expressão na forma de canção é central para a organização desse relato. Assim, usaremos os elementos rítmicos e melódicos pertinentes para apoiar e evidenciar relações que, de outra forma, estariam sub-representadas na letra.

Como a história nos é apresentada em uma canção, ela é organizada em curvas melódicas que se repetem com variações na letra. Oferecemos, abaixo, o texto verbal organizado a partir da sua relação com a melodia. As letras maiúsculas indicam cada uma das três partes (a cada vez que mudam as letras, a melodia será retomada do início e repetida). Os algarismos arábicos representam uma frase distinta. ${ }^{6}$ A repetição do algarismo equivale

\footnotetext{
${ }^{6}$ Não estamos nos fiando à terminologia musical. Entendemos por frase apenas uma sequência que corresponde aproximadamente a uma frase verbal e que tem uma certa
} 
à repetição da curva melódica. Assim, por exemplo, A1 e B1 têm letras distintas, mas a mesma melodia; A1 e A2 têm curvas melódicas distintas, mas participam da primeira parte da música.

\begin{tabular}{l|l}
\hline \hline A1 & Miss Otis regrets she's unable to lunch today \\
\hline A2 & Madam, Miss Otis regrets she's unable to lunch today \\
\hline A3 & She is sorry to be delayed \\
\hline A4 & But last evening down in Lover's Lane she strayed \\
\hline A5 & Madam, Miss Otis regrets she's unable to lunch today \\
\hline \hline B1 & When she woke up and found that her dream of love was gone \\
\hline B2 & Madam, she ran to the man who had led her so far astray \\
\hline B3 & And from under her velvet gown \\
\hline B4 & She drew a gun and shot her lover down \\
\hline B5 & Madam, Miss Otis regrets she's unable to lunch today \\
\hline \hline C1 & When the mob came and got her and dragged her from the jail \\
\hline C2 & Madam, they strung her upon the old willow across the way \\
\hline C3 & And the moment before she died \\
\hline C4 & She lifted up her lovely head and cried \\
\hline C5 & Madam, Miss Otis regrets she's unable to lunch today \\
\hline \hline
\end{tabular}

Além da tripla repetição melódica e do fato de cada repetição conter cinco frases, há outras recorrências importantes a notar. A primeira delas é a insistência na frase "Miss Otis regrets she's unable to lunch today". 7 Essa frase é peculiar por uma série de fatores. Primeiramente, ela encerra as três partes (em negrito na nossa tabela). No entanto, ela é muito pouco coesão melódica.

${ }^{7}$ Tradução livre: "Miss Otis sente não poder almoçar hoje". 
informativa. Não fosse o fato de ela ser repetida sem alteração ${ }^{8}$ alguma nas cinco vezes em que aparece na canção, ela expressa uma fórmula de polidez que, pela própria fixidez de seus termos, ganha um desgaste semântico.

Poderíamos, então, interpretar essa frase como mero pano de fundo: um elemento organizador que garante um lugar de repouso para o enunciatário da canção; algo como um refrão (Tatit, 1997: 24). Não negamos também esse papel: a fórmula feita associada ao conteúdo conhecido e retomado aponta para esse desgaste semântico e para uma cifra tensiva de pouco impacto. No entanto, a repetição é por demais regular e frequente (cinco recorrências numa canção de quinze frases). Mais ainda, há um descompasso radical entre a "pobreza" semântica dessa frase e o caráter trágico do relato que permeia suas ocorrências. A presença insistente da mesma frase e o descompasso patêmico entre as partes do texto sugerem que a equação tensiva é um pouco mais elaborada.

Apontamos no Capítulo 4 que a repetição insistente nega o progresso discursivo e, em função do caráter opositivo da linguagem, clama por uma retomada de direção. Em outras palavras, a repetição produz uma estagnação no texto: não há mudança, não há transformação, não há percurso, há apenas grandes ciclos que apontam sempre para o início do texto. A permanência nesse estado cria uma tensão, uma expectativa de retomada do percurso. Também aí poderíamos argumentar em favor de uma oscilação entre a frase que se reitera e a narração que avança. No entanto, iremos um pouco mais longe dizendo que o que se passa é uma ressemantização

\footnotetext{
${ }^{8}$ Há apenas alteração melódica em A1 e A2, mas A5, B5 e C5 têm inclusive a mesma melodia.
} 
da frase desgastada, ou seja, a cada passo da narrativa que se desenrola, reinterpretamos a frase sempre num crescendo de sentido e tensão.

\subsubsection{Os Grandes Ciclos da Narrativa de Miss Otis}

Veremos, então, de que forma a frase repetida pontua cada parte, encerrando os ciclos da narrativa. A cada nova fase, veremos um recrudescimento da tensão, associado a um incremento de sentido atribuído à frase, que se distancia pouco a pouco do seu estatuto de fórmula de polidez.

A narrativa se inicia por um aviso de que Miss Otis não comparecerá ao almoço planejado. O recado parece ser transmitido por um(a) empregado(a), dado o distanciamento nas fórmulas de tratamento: o uso de título e sobrenome para Miss Otis e o vocativo polido "Madam". ${ }^{9}$ Podemos ainda ir além e supor que esse empregado é, na verdade, uma mulher. Essa suposição está fundada em elementos mais sutis da tomada de posição desse ator-narrador. Não se trata de um relato isento. Há um posicionamento em favor da Miss Otis e uma familiaridade na descrição do vestido, na referência ao seu estado passional ("in Lover's Lane she strayed"), ${ }^{10}$ no adjetivo "lovely". ${ }^{11}$ Desenvolveremos as consequências dessas observações mais adiante, mas desde já podemos associar essa aproximação do narrador com Miss Otis, somada às fórmulas de tratamento, à figura da dama de companhia, da aia, talvez de uma escrava. O papel temático da aia que toma o partido da moça que acompanha em detrimento da avaliação da

\footnotetext{
${ }^{9} \mathrm{O}$ vocativo pode ser traduzido por "minha senhora" ou uma das inúmeras corruptelas que o português conhece: "sinhá", "iaiá", etc.

${ }^{10}$ Tradução livre: "ela se perdeu no caminho dos apaixonados".

11 "Lovely" pode ser traduzido por "graciosa".
} 
coletividade ou de um dever em relação aos patrões encontra paralelos clássicos na literatura. ${ }^{12}$

Depois de dado o recado da ausência da ama, a aia explica que na noite passada Miss Otis se perdeu numa forte experiência amorosa ("But last evening down in Lover's Lane she strayed"). Ora, já aí temos um contraste importante entre a programação da frase feita e uma intencionalidade ou uma sensibilidade trazida pela referência ao impacto afetivo (Landowski, 2007), mas o relato ainda está vago e podemos supor apenas uma dor amorosa que não entra em grande choque com a figura de uma aristocrata que se desenha. ${ }^{13}$ Sendo assim, as primeiras ocorrências dessa frase central não estão, afinal, tão problematizadas.

Em seguida, na parte a que chamamos B, a aia vai apresentar mais um desenvolvimento da narrativa. Miss Otis, se descobrindo enganada, vai até seu amante e o mata a tiros. A expressão em inglês "shoot down" não implica necessariamente a morte, mas frequentemente sim. ${ }^{14}$ A continuação da história e a sanção que recebe Miss Otis fazem crer que o desfecho foi de fato a morte do amante.

Entra aqui um outro desdobramento da história. Miss Otis cometeu um crime. Saímos mais claramente do circuito doméstico de uma mulher que sofre por amor e entramos na esfera pública. A ausência da protagonista

\footnotetext{
${ }^{12}$ Ver o papel da aia em "Romeo and Juliet", de William Shakespeare (1982).

${ }^{13}$ Outras figuras vão reforçar a ideia de que Miss Otis é uma aristocrata, mas o fato de ter uma criada e estabelecer compromissos de almoço com outras senhoras a quem se deve dirigir por "madam" já dão pistas de seu estatuto social.

${ }^{14} \mathrm{O}$ Cambridge Advanced Learner's Dictionary On-line apresenta a seguinte definição para "shoot down": atirar e, em geral, matar alguém sem demonstrar nenhuma empatia (Tradução nossa para: "to shoot and usually kill someone, showing no sympathy" (http://dictionary.cambridge.org/dictionary/british/shoot-sbdown?q=shoot+down\#shoot-sb-down_2)).
} 
para o almoço, mais uma vez repetida ao final da parte $B$, ganha outra dimensão: ela está agora impedida de ir talvez por uma determinação legal (a essa altura ainda não sabemos).

Entretanto, mais importante que as questões pragmáticas envolvidas com o seu compromisso perdido, o que esse novo trecho nos apresenta é um acréscimo passional maior do que aquele que se colocou na primeira parte. Por meio do fazer de Miss Otis, percebemos uma forte mobilização patêmica. Sua atitude, somada à ferida amorosa, toma as configurações de uma vingança ou mesmo de uma reação colérica. Na esteira do conhecido artigo de Greimas (1983) “De la colère: étude de sémantique léxicale”, sabemos que essas reações passionais, que instauram um sujeito do fazer, onde antes só havia um sujeito de estado, são precedidas de um encadeamento narrativo que envolve uma crise fiduciária e objetal. Se, por um lado, essa crise fiduciária e objetal conclui um contrato amoroso suposto nas figuras do amante e do "Lover's Lane", por outro lado, é condição necessária (ainda que não suficiente, como aponta Greimas) para o início de um programa de compensação: nesse caso, o assassinato do amante.

É por meio desse encadeamento narrativo e jogo de pressuposições que o fazer de Miss Otis nos apresenta também o seu estado passional. Por definição, só nos é dado ver o parecer: "o olhar alheio, portanto, tem somente o parecer como base de inferências sobre o ser do sujeito" (Harkot-de LaTaille, 1999). Essa característica - que forma também um postulado teórico da semiótica - é ainda mais acentuado nesse texto pela debreagem enunciva e a instauração de um narrador não-onisciente (Barros, 2001 : 83), além de francamente distanciado por conta de sua posição social. Fica, assim, es- 
clarecida a relação que apontamos acima de que é principalmente por meio do fazer que chegaremos a indícios do estado passional da protagonista.

No episódio seguinte $(C)$, confirma-se a sanção negativa pela prisão de Miss Otis, para logo ser substituída por uma outra forma mais cabal. Miss Otis é tirada da cadeia por uma multidão para ser enforcada. Novamente, é preciso reinterpretar a frase: Miss Otis não virá não apenas por estar detida, mas por estar morta.

Como vimos, então, o desdobramento pragmático do crime conduz a uma reinterpretação da frase "Miss Otis regrets...", assim como a sua morte subsequente traz uma "definitude" contraditória à transitoriedade aparente do "today" ("hoje") — como se o compromisso pudesse ser retomado no futuro. Ademais, também a dimensão passional ressignifica a frase. Esse caminho é um tanto mais sutil. Por um lado, vemos a criação de uma escala que vai de uma disposição patêmica forte - a infelicidade amorosa - a uma sanção negativa externa e forçada na forma da prisão, culminando no extremo da sanção com a morte da protagonista. O componente trágico vai, assim, recrudescendo e, portanto, se afastando cada vez mais da frase feita. Dito de outra forma, o contraste entre a história de Miss Otis e o recado da criada vai ficando a cada vez mais marcante.

Podemos considerar a frase que anuncia a ausência de Miss Otis e as razões para sua ausência como pertencentes a camadas distintas da história. Nesse sentido, o tom trágico da narrativa não se deixaria transferir para a frase fria e corriqueira. Algo se perde, porém, no sentido do texto se esse caminho for escolhido. A canção forma um todo de sentido e isso quer dizer que esperamos que as partes mantenham relações entre si e 
com esse todo. A justaposição de elementos discrepantes está na raiz de uma poeticidade. $\mathrm{O}$ contraste da frase corriqueira com o acontecimento excepcional choca as expectativas do enunciatário e transpõe a força do acontecimento do nível do enunciado para o nível da enunciação.

A percepção de que a cada enunciação da frase "Miss Otis regrets..." há uma mudança de sentido e, mais ainda, um caminho na direção de maior disjunção está bastante ressaltado na excepcional interpretação de Ella Fitzgerald. Três vezes a frase “Madam, Miss Otis regrets she’s unable to lunch today" é repetida no fechamento de cada parte. Na partitura que usamos para efeitos de comparação (Porter, 1959:60-62 - Anexo II), ${ }^{15}$ a curva melódica é a mesma para as três ocorrências. Não na versão de Ella. A primeira frase é realmente muito próxima da versão em papel. Já a segunda sofre importantes alterações. Para a nota que equivale à sílaba "Ma" de "Madam", a intérprete sobe cinco semitons, de tal forma que “Madam" não é mais cantado de forma ascendente, mas descendente. $\mathrm{O}$ mesmo com "Miss Otis": sobe três tons para "Miss" e desce para "Otis". Por si só essas alterações já desestabilizam as expectativas, pois desenham uma curva com direção diferente da partitura. No entanto, a análise pode ir além.

No arranjo da partitura, "Otis regrets she's unable to" traz todas as sílabas cantadas na mesma altura. Nessa frase da parte B, Ella canta "un-"

\footnotetext{
${ }^{15}$ A partitura retirada do songbook de Cole Porter não apresenta o tom escolhido por Ella Fitzgerald. Todas as observações que faremos acerca de alterações nas alturas realizadas pela intérprete e as anotações feitas à mão na própria partitura são tomadas proporcionalmente, ou seja, como se tivéssemos transposto a canção para o seu tom. Assim, não usaremos as notas em si, mas uma relação de quanto a cantora subiu ou desceu em semitons por relação ao esperado que ela cantasse, estivesse a partitura adaptada para sua voz.
} 
nove semitons abaixo. Ao fazer isso, aumenta enormemente a tessitura da música, que até então não contava com nenhuma nota tão grave. Tatit (1997:25) observa uma "correspondência quase imediata entre as grandes inflexões melódicas de tessitura e as tensões emocionais reveladas pelos cantores de temas românticos."16 As canções de temas passionais, ao explorar mais as variações de altura, tendem a colocar em evidência a disjunção do sujeito e seu objeto. Nesses termos, há uma associação entre os saltos intervalares e a cisão entre o sujeito e o objeto. Assim, ao ampliar a tessitura musical, a intérprete põe mais ênfase no caráter disfórico da letra que se apresenta.

Na conclusão da terceira parte, Ella Fitzgerald também manipula as alturas, mas numa outra direção. Ao invés de subir um pouco no início para, em seguida, fazer um grande salto descendente, ela promove diretamente um salto para a nota mais aguda da canção, que também não estava prevista na partitura. Ao cantar a sílaba "Miss" sobe dez semitons em relação à nota original. ${ }^{17}$ Essa mudança também gera, localmente, um salto importante em relação às notas vizinhas e muda a curva melódica. No entanto, mais central que isso é o fato de que, ao emitir na segunda frase uma sílaba nove semitons abaixo da versão da partitura e, na terceira, uma nota dez semitons acima, Ella transforma a tessitura da canção, tornando-a muito mais passional. No contexto da frase feita, ao inscrever modulações de altura numa frase originalmente mais regular e produzir diferenças a

\footnotetext{
${ }^{16}$ Para maiores detalhes do papel da tessitura, da direção da curva melódica e dos saltos, e do andamento na construção de canções passionais, ver Tatit (2007b: 94-128).

${ }^{17}$ Também na sílaba "-ble" (da palavra "unable"), sobe oito tons em relação ao arranjo anotado.
} 
cada interpretação, Ella Fitzgerald parece refletir na expressão melódica as variações de sentido que a frase adota a cada vez que é enunciada e a cada momento que conhecemos uma nova parte da narrativa.

Essa amplitude melódica aparece num outro trecho da canção, mas também por escolha da intérprete (não estava prevista na partitura). Na sequência final da narrativa, no momento em que está prestes a morrer, Miss Otis levanta os olhos para o céu e chora, numa forte alusão à figura clássica da Pietà. A letra diz: "And the moment before she died / she lifted up her lovely head and cried". "The" é a sílaba mais grave e "-ly" (de "lovely") é a mais aguda, numa distância total de dezessete semitons.

Nesse processo de manipulação de alturas associado à ideia de que a frase permeia e pontua a história de Miss Otis, começamos a sair da monotonia da frase feita e a entrar num processo de ressignificação daquilo que antes era desgastado.

\subsubsection{Duas Formas de Emergência do Sentido}

Já sugerimos acima que, para sentirmos o impacto do relato de Miss Otis, é preciso reconhecer uma transposição da força do acontecimento do narrado para a enunciação, como num sincretismo de níveis. Vamos aqui passar a traçar novos paralelos e relações para mostrar que operações estão na base dessa relação, ou seja, por que não há isenção e verdadeiro distanciamento entre as duas instâncias.

Numa discussão acerca das propostas semióticas para o tratamento do sensível, Eric Landowski (2005:101-104) cria uma escala que tem, como 
pontos extremos, duas instâncias de não-sentido: de um lado, o contínuo absoluto do cotidiano, tornado banalizado pela insignificância, de outro, o excesso de descontinuidades e quebras, o caos do aleatório tornado insensato. ${ }^{18}$ Propomos interpretar o fazer de Miss Otis e sua Aia como duas ocorrências de instauração do sentido por meio dos processos de negação do não-sentido, conforme previsto por Landowski.

\section{O Trajeto de Miss Otis}

O descontínuo aleatório, para Greimas (1987), está ligado à fratura estética que introduz o sensível no mundo insignificante do cotidiano. No entanto, Landowski (2005: 103) sugere que, se generalizarmos a questão, esse acidente pode ser de qualquer ordem e, portanto, o descontínuo pode surgir de forma disfórica. Na história de Miss Otis, a traição ou a decepção amorosa toma a forma desse descontínuo devastador. Se uma traição é um lugar comum no universo literário e na vida cotidiana, a percepção daquele que é traído será condicionada pela imagem de si mesmo e do outro que construiu e a dimensão que toma o evento que vem romper essa confiança na imagem (Harkot-de-La-Taille, 1999; Harkot-de-La-Taille \& Taille, 2004). Sendo assim, a traição pode surgir como insensata. Trata-se da irrupção de um acontecimento disfórico que coloca o sujeito na modalidade do sofrer (Zilberberg, 2012: 20-21, 29).

Como já apontamos anteriormente, não nos é dado ver detalhes das

\footnotetext{
${ }^{18}$ Os dois polos propostos por Landowski guardam semelhanças aos extremos especulativos que discutimos em 4.2 acima. Entretanto, estávamos ali tratando de limites impossíveis, de não-textos. Landowski, por sua vez, está no limiar do não-sentido, do tédio e do insensato: todas possibilidades plausíveis, ainda que raras e limítrofes.
} 
condições que levaram Miss Otis a atirar em seu amante, mas a violência de sua reação faz supor uma intensa decepção. Miss Otis parece, então, buscar ultrapassar o insensato daquilo que lhe sobreveio, por meio da restauração de uma ordem (Landowski, 2005 : 102), uma busca pelo equilíbrio rompido (Greimas, 1983:241; Zilberberg, 2011b:169).

Em termos de fluxos aspectuais, a traição ou decepção inferida no texto ("the man who had led her so far astray") ${ }^{19}$ configuram uma parada na continuação, ou seja, o evento aleatório previsto por Landowski que perturba a ordem e rompe a possibilidade de trajeto. Para Zilberberg (2011b : 168), esse evento aleatório tem a configuração de um acontecimento: “[no] 'calor' do acontecimento - o 'calor' é uma metáfora que remete ao ápice, ou seja ao paroxismo da intensidade - a afetividade está em seu auge e a legibilidade é nula." É importante para a relação entre a teoria de Landowski e a de Zilberberg a questão da ausência de "lisibilidade". No auge do acontecimento, é impossível ao sujeito compreender o seu sentido.

A escolha de vocabulário é bastante significativa: "But last evening down in Lover's Lane she strayed". O verbo "stray" supõe um desvio do caminho, perda de direção. A permanência nesse estado (continuação da parada) é insuportável, é a permanência no não-sentido. Assim, a ação da protagonista vai na direção da retomada do fluxo: a parada da parada (Zilberberg, 2006b:147). O quadro apresentado na página 132 e reproduzido abaixo ilustra esse agenciamento de fluxos:

\footnotetext{
${ }^{19}$ Tradução livre: "o homem que a tinha tirado de seu rumo".
} 


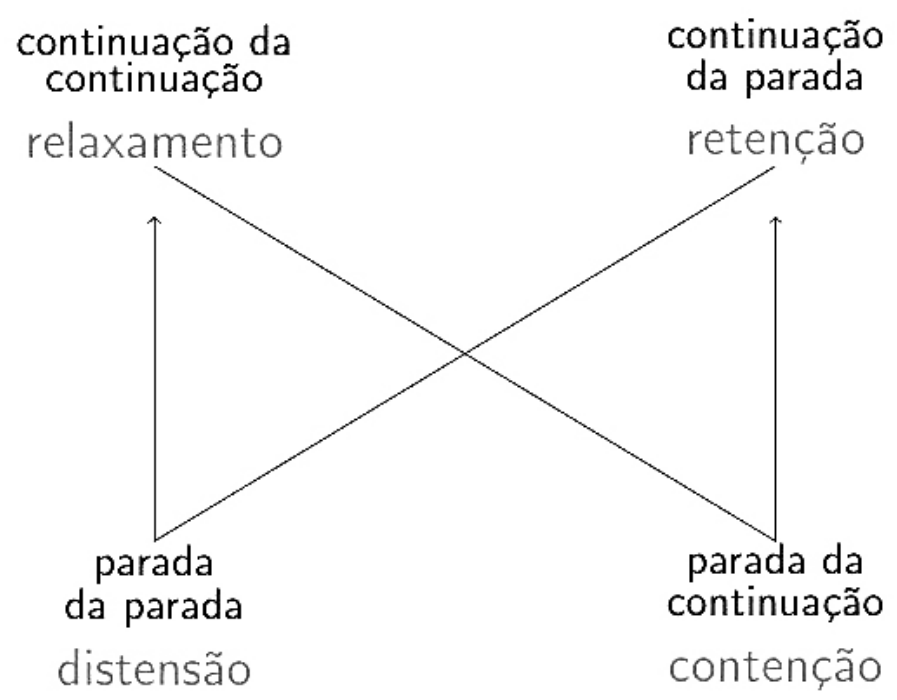

Figura 5.1 - Esquema de paradas e continuações

Voltando aos termos de Landowski, ao caos do acaso segue-se uma busca pela ordem na ação de Miss Otis. Entretanto, como descobriremos na terceira parte, ao agir dessa forma, a protagonista não adotou um destinador condizente com os valores do grupo em que circula, que exige certas linhas de comportamento (Harkot-de La-Taille \& Taille, 2004 : 22-24). Não agindo, então, segundo os valores considerados "corretos" pelo grupo, uma nova sanção virá de fora. O grupo nega mesmo a sanção despassionalizada da justiça (Greimas, 1983 :243-244): “when the mob came and got her and dragged her from the jail". ${ }^{20}$

Harkot-de La-Taille \& Taille (2004 : 24-25) apontam um contraste entre uma cultura mais individualista atual e um mundo mais tradicional de valores que começa a perder força a partir da década de 1950. Essa oposição parece estar instaurada em nossa história. Os valores coletivos não

\footnotetext{
${ }^{20}$ Tradução livre: "Quando a multidão veio e apanhou-a e arrastou-a da prisão".
} 
adotados por Miss Otis lhe são impostos pelo grupo de que participa, da forma mais definitiva possível. Apesar de ser essa a história que nos é relatada, tal posição não é a que permanece como valor central do texto para seu enunciatário.

\section{A História da Aia}

Abordamos, acima, o percurso de Miss Otis tomado sob uma perspectiva interna dos "interlocutores", ou seja, ora do ponto de vista da protagonista, ora do grupo que escolhe puni-la. No entanto, a história é contada por um narrador. A aia traz, em seu relato, uma outra posição. Ao descrever a protagonista com figuras de aproximação e delicadeza, falando de seu estado passional, descrevendo seu vestido, usando um adjetivo como "lovely" e construindo a figura da Pietà, que comentamos anteriormente, a criada se coloca em oposição à violência da descrição da cena de enforcamento. Na frase "when the mob came and got her and dragged her from the jail", temos a figura da multidão que arrasta Miss Otis para fora da cadeia. Se a ideia de arrastar alguém para fora de um lugar difícil de sair como a prisão já sugere um grau de violência, sua associação aos traços aumentativos e desordenados da noção de multidão, onde não uma, mas várias pessoas agem sobre uma única mulher, torna a violência do ato extrema. A aia apresenta, assim, um outro valor, uma nova sanção, oposta à axiologia do grupo. $^{21}$

\footnotetext{
${ }^{21}$ A análise de Tatit (2001:45-55) para a letra de "Quando o Samba Acabou”, de Noel Rosa, encontra a mesma alternância de axiologia: os malandros decidem que aquele que perde a disputa, perde a namorada. O vencido acaba por se matar na encruzilhada. Rosinha, objeto dos malandros, sanciona diferentemente e presta homenagem ao malandro que cometeu o suicídio. Não há uma figura de narrador instaurado no texto como em
} 
Sua posição como narradora tem força sobre toda a narrativa por ser englobante, conforme ilustrado no esquema de Barros (2001:75) reproduzido aqui:

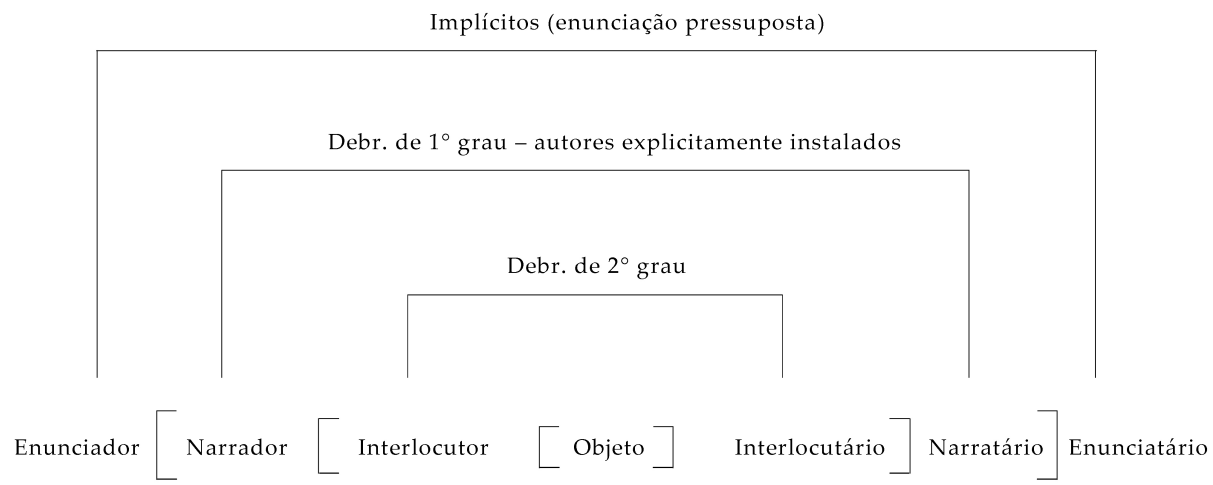

Figura 5.2 - Esquema da esfera de ação dos agentes do discurso

Ao contar a história, o narrador realiza um fazer pragmático de comunicação e um fazer cognitivo, no qual demonstra um saber, mas também realiza uma sanção (Greimas \& Courtés, 2011:327). O fazer cognitivo é “hierarquicamente superior à dimensão pragmática que lhe serve de referente interno" (Greimas \& Courtés, 2011:64). No entanto, a aia não é o destinador legítimo dessa narrativa, uma vez que não pode interferir na sanção pragmática e sua performance é principalmente cognitiva.

A esfera pragmática de sua ação está no diálogo suposto pela expressão “Madam". Toda a canção se apresenta no registro enuncivo. A única ocorrência enunciativa é esse vocativo. No componente verbal, o vocativo é um "Miss Otis Regrets", mas há uma figura mais abrangente da lua que acompanha a sanção de Rosinha: "de noite não houve lua, ninguém sambou". 
elemento estrangeiro: não se liga sintaticamente a nenhuma outra palavra da frase, pode ser inserido no início, no meio ou ao final da oração, enfim, não há uma restrição ou conexão com os demais elementos. Na canção, essa posição ímpar é acentuada pela estrutura harmônica: o compositor escolhe não usar de notas tônicas (que caracterizariam uma conclusão de frase), nem dominantes (que são usadas para introduzir uma nova frase, uma resposta) para a expressão "madam", ambas formas consagradas de passagem de uma frase a outra. "Madam" aparece entre as frases, quebrando a estrutura de pergunta e resposta. A interpretação de Ella Fitzgerald vai além e cria um contraste rítmico entre "madam" e as frases em volta, que não estava previsto na partitura. ${ }^{22}$ Esses contrastes põem em relevo a única instância enunciativa, acentuando a característica de diálogo.

Voltando à frase feita, núcleo do recado da ausência de Miss Otis, vemos aí os ares da programação, do contínuo monótono e insignificante. A frase, como dissemos, é dessemantizada pelo desgaste do uso; é a outra figura do não-sentido de que trata Landowski (2005 : 102): aquela que se dá pela continuidade ininterrupta. Todavia, ao repetir tantas vezes a mesma frase, cria-se um desconforto: é a continuação do vazio de sentido. Nos termos que discutimos anteriormente, a própria repetição sem alterações já é um princípio de ressignificação, minimamente pela criação do incômodo que toma a forma de uma pergunta: para quê repetir se o recado já foi dado?

\footnotetext{
${ }^{22}$ A célula rítmica original era colcheia-semínima-colcheia (ver na partitura a primeira ocorrência de "O-tis re"). Ella canta essa célula como semínima-colcheia-colcheia, exceto em "madam", que mantém o ritmo da versão escrita. Em outras palavras, onde antes havia uma identidade rítmica entre as partes (todas cantadas a partir da mesma célula rítmica), a cantora cria uma diferença, aumentando a estranheza de "madam" por relação ao resto.
} 
Aonde vamos se não vamos a lugar nenhum? Mais ainda, a narradora não se contenta em repetir o recado programado e escolhe contar a história por trás da ausência. Assim, nega o contínuo e instaura o sentido através de sua ação, que destoa e contrasta com a frase feita e pouco semantizada.

Toda a mobilização passional está no narrado. A narração privilegia o fazer cognitivo, a dimensão inteligível. Ela promove a distância necessária para que possamos entender a relação entre os eventos que se sucedem. No entanto:

não é possível opor conceitualmente o sentir, com o seu caráter imediato, à reflexividade do conhecer, nem separá-los analiticamente. [...] essas duas formas complementares de um único saber sobre o mundo misturam-se e, provavelmente, até se reforçam uma a outra. (Landowski, 2005 :95)

Por essa relação simbiótica entre sentir e conhecer e por toda a relação que apontamos entre o narrado e a narração, a dimensão passional da história de Miss Otis permeia todos os níveis do enunciado.

A posição social da aia, associada ao fato de que se dirige a uma figura aristocrática ("Madam”), cria o contraste da posição doméstica com a posição social. Há, portanto, uma “intertextualidade 'interna' de vozes que falam e polemizam no texto" (Barros, 1994:4). Isso promove, além de uma mudança nos valores axiológicos do texto e uma transferência de esferas passionais, uma outra forma de poeticidade. Segundo a proposta de Barros (1994:6), opõem-se discursos autoritários, monofônicos, e discursos poéticos, polifônicos. Estes últimos são os que instalam "internamente, graças 
a uma série de mecanismos, o diálogo intertextual, a complexidade e as contradições". Assim, tendo esse vocativo posto em destaque por mecanismos verbais e musicais - tanto da composição como da interpretação —, como eixo da explicitação da polifonia, cria-se um texto poético que é esteticamente trabalhado e ideologicamente comprometido.

\subsubsection{O Lugar da Enunciação}

Nesse estudo, investigamos as relações entre o narrado e a narração. Argumentamos que, por meio de mecanismos verbais e musicais, os estados de alma mobilizados no narrado eram transpostos para a narração de tal forma a criar o tom trágico e passional da canção. ${ }^{23}$ É assim que a oscilação entre a frase feita e as partes da narrativa, as escolhas de figuras, a exploração da tessitura melódica, os contrastes rítmicos criam relevos no enunciado.

Ao observarmos esses agenciamentos sintáxicos do texto, faz-se entrever a figura do enunciador de que ainda não tratamos. Permanecemos na figura do narrador. No entanto, o narrador é "um ator que engloba os papéis actanciais de Sujeito e Destinador discursivos" (Barros, 2001 :81). Se ele nem sempre reflete a posição do enunciador, ${ }^{24}$ em "Miss Otis Regrets", narrador e enunciador parecem estar sincretizados. Isso fica claro se, mais uma vez, considerarmos a relação entre o componente verbal e o musical.

Todos os pontos que levantamos acima acerca da melodia e do ritmo

\footnotetext{
${ }^{23}$ Fossem distanciadas as instâncias, talvez se criasse um texto cômico. As histórias dos palhaços de que tanto rimos são frequentemente trágicas, não fosse a forma de apresentação.

${ }^{24}$ Ver estudo de Cruz (2009) acerca da relação polêmica entre narrador e enunciador na obra de Machado de Assis.
} 
foram no sentido de destacar a narração (como, por exemplo, o papel de "madam" no relato). Um outro exemplo musical talvez dê a exata dimensão dessa relação. Na frase quatro de cada parte (A4, B4 e C4), o compositor insere mais um compasso alongando o resultado. Na interpretação, Ella Fitzgerald, de forma distinta, também alonga os tempos. Ora, esse é o trecho de maior mobilização passional em todas as partes no componente verbal. Ao determinar maior permanência ali onde há maior carga afetiva, $\mathrm{o}$ enunciador acentua a tristeza do relato da aia. Para Landowski $(2005: 104)$, o fazer estético do sujeito é uma:

atividade que pressupõe uma vontade consciente para sustentar a busca do valor e do sentido - e que necessita uma certa extensão temporal, de tal maneira que o encontro com o sentido aparecerá então com o resultado de um processo interativo e não mais como um dom gratuito.

Por mais contraditório que possa parecer, ao repetir o recado, a aia está abandonando os deveres de uma breve missiva e empreende seu tempo em relatar a história de Miss Otis. Também assim o enunciador alarga as temporalidades e constrói um objeto de valor. 


\subsection{Balanço}

Conforme proposto acima, apresentamos duas análises que se sustentam em si e cujas conclusões não estão a serviço da tese principal desta pesquisa. Ainda assim, vimos que a repetição tem papel central na composição de cada texto. Não sendo fator exclusivo, é de todo modo fundamental na estruturação que sustenta o sentido global.

Vimos que Claude Zilberberg (1996:27-29) propõe três formas de progressão textual baseadas nos recortes aspectuais: circular, linear e espiral — esta última uma conjugação das duas primeiras. Propusemos então transpor essas categorias para a progressão da repetição em si e seu papel no desenvolvimento do texto como um todo. O poema de João Cabral parece ser um claro exemplo de progressão espiral, sobretudo no vocabulário, em que palavras são paulatinamente acrescentadas, repetidas e abandonadas, numa sobreposição em que o novo é introduzido antes que o velho tenha desaparecido de todo. A manifestação das categorias circular e linear, porém, é de mais difícil precisão.

As características da progressão circular são o fechamento, a intransitividade, a finitude. Poderíamos dizer que são atributos de toda repetição. No entanto, escolhemos o poema de T.S. Eliot em que a repetição utilizada como exemplo está confinada a uma estrofe. Essa não é a única repetição do poema e, de fato, as repetições se fecham em pequenos círculos sucessivos, sem a intercessão verificada no poema de Cabral. Apresentamos aqui alguns outros trechos do poema "The Hollow Men", nos quais diferentes repetições locais se apresentam: 
I We are the hollow men

We are the stuffed men

Leaning together

Headpiece filled with straw.

\section{Alas!}

Our dried voices, when

We whisper together

Are quiet and meaningless

As wind in dry grass

Or rats' feet over broken glass

In our dry cellar

Shape without form, shade without colour,

Paralysed force, gesture without motion;

Those who have crossed

With direct eyes, to death's other Kingdom

Remember us - if at all — not as lost

Violent souls, but only

As the hollow men

The stuffed men.
II Eyes I dare not meet in dreams

In death's dream kingdom

These do not appear:

There, the eyes are

Sunlight on a broken column

There, is a tree swinging

And voices are

In the wind's singing

More distant and more solemn

Than a fading star.

Let me be no nearer

In death's dream kingdom

Let me also wear

Such deliberate disguises

Rat's coat, crowskin, crossed staves

In a field

Behaving as the wind behaves

No nearer -

Not that final meeting

In the twilight kingdom

Note-se que as repetições elencadas, não são sequer de mesma natureza: a primeira, em itálicos, é uma repetição vocabular; a segunda, em negrito, uma repetição sintática associada a uma reiteração sonora (shade / shape); por fim, a terceira, sublinhada, repete também palavras, mas em outra 
posição sintática (na primeira, eram predicativos do sujeito; na segunda, adjuntos de lugar) e com uma pequena alteração (as palavras "death's dream" são substituídas por "the twilight"). A análise poderia ser mais detalhada se fosse esse o nosso objetivo e encontraríamos ligações isotópicas e até mesmo palavras isoladas retomadas aqui e ali. Ainda assim, é possível reconhecer uma independência maior entre as repetições no poema de Eliot do que aquelas do poema de João Cabral. Em outras palavras, se os estilos não se separam de forma radical, eles são, ainda assim, claras tendências na organização textual da repetição.

Por fim, o modo linear sugere a abertura, a transitividade e a infinitude - características não intuitivamente ligadas à repetição. Ao mesmo tempo, o texto forma necessariamente um todo analisável e, em última instância, encerra-se, acaba. Sendo assim, a linearidade como modo de progressão não está apontando para o infinito absoluto, mas para um fechamento mais distante: para a perspectiva global. Esse é o caso da repetição do recado de ausência em "Miss Otis regrets". Não apenas sua repetição está distribuída por todo o texto, mas, por seu caráter englobante da história narrada, a frase abarca e contextualiza toda a narrativa. Por outro lado, encontramos um caráter propriamente linear na interpretação da frase que não é nunca a mesma, progredindo junto com a narrativa.

Nos exemplos mencionados, "circular" parece se associar a "local" ou "intenso" e "linear", a "global" ou "extenso", o que não é sem razão. As questões do todo e da parte, da totalidade e da localidade pressupõem as demarcações e segmentações aspectuais. Nesses termos, estamos diante de duas perspectivas reunidas pela sua dependência do aspecto. "Circular", 
"linear" e "espiral" são modos de progressão da repetição no texto. "Local" e "global" são âmbitos de pertinência das iterações. 


\section{Conclusão}

Como escrever senão sobre aquilo que não se sabe ou que se sabe mal? É necessariamente nesse ponto que imaginamos ter algo a dizer. Só escrevemos na extremidade do nosso próprio saber e nossa ignorância e que transforma um no outro.

Gilles Deleuze 
Em Des Formes de vie aux valeurs, Claude Zilberberg (2011a) parte de uma discussão acerca da tão comentada busca frenética pelo novo na modernidade. Um desejo de que não escapamos, nem a autora desta tese, nem o grande semioticista francês. Uma tese insere-se, no entanto, numa tradição, num percurso. Especialmente em semiótica, um texto se faz de outros textos e a novidade parece de difícil acesso. Zilberberg nos oferece então duas vias: a modificação do campo de presença a partir da inserção de um novo objeto, como foi o caso do inconsciente na teoria freudiana; ou a transferência do acento de sentido, como foi feito com a arbitrariedade por Saussure e com a tensividade nos estudos do próprio semioticista. Consideramos muito feliz a saída da novidade pela transferência de ênfase e percebemos que, em grande medida, é isso o que buscamos fazer nesta tese.

Ao colocar a repetição no centro de nossa investigação, produzimos um rearranjo dos demais instrumentos teóricos, que passaram a girar dentro dos limites desta tese - em torno do esclarecimento do fenômeno sob análise. Assim como todo estudo de perspectiva semiótica, é menos o porquê do que o como que interessa. Responder o porquê das coisas é assunto de outras disciplinas, uma vez que, por sua recursividade infinita, é o tipo de questão que leva à transcendência: em última instância, a resposta do porquê esbarra no não-saber ou numa explicação que escapa à esfera do homem. Sendo esta tese, de sua concepção à redação final, um estudo que busca a imanência, ficamos com as seguintes perguntas: como age a repetição no texto? Quais são as condições de seu aparecimento e funcionamento? 
Se voltarmos à sugestiva formulação de Lévi-Strauss com a qual abrimos esta tese: “[a] repetição tem uma função própria, que é a de tornar manifesta a estrutura do mito" (ver página 3), vemos que foi esse o nosso percurso, não mais na ordem do mito, mas na ordem do texto, ou seja, o estudo aqui empreendido parece mostrar que a repetição de fato manifesta uma estrutura, inclusive mais abrangente do que a sugerida pelo antropólogo francês. Chegamos à conclusão de que a repetição é uma manifestação possível de um princípio de arranjo sintagmático, bem como de tensões que impulsionam e determinam o fluxo textual. O desfecho é talvez menos importante que o trajeto percorrido (ou ao menos igualmente relevante).

Inventários como aqueles apresentados no primeiro capítulo são construídos de forma indutiva: das ocorrências individuais a uma generalização mais ou menos abrangente, segundo o escrutínio do pesquisador. Ao partirmos do elemento manifestante para chegar à estrutura manifestada, fizemos o caminho logicamente inverso. Tomamos o todo com seus elementos gerais e fortuitos e, ao analisá-lo, chegamos a seus componentes mais simples e constantes. Esse é o procedimento prescrito pela teoria hjelmsleviana e adotado para a constituição dos instrumentos teóricos da semiótica tensiva. É também o que foi intuído por Walt Whitman (1891:31) neste trecho de "Song of Myself": "Lack one lacks both, and the unseen is proved by the seen, / Till that becomes unseen and receives proof in its turn." 25 , em que o poeta norte-americano propõe que se parta da experiência imediata para ir na direção daquilo que está inacessível aos olhos. A consequência

\footnotetext{
${ }^{25}$ Nossa tradução livre: "Se falta um, faltam ambos, e o invisível se prova pelo visível / Até que este se torne invisível e seja provado, por sua vez."
} 
do procedimento dedutivo é que, ao recortar homogeneamente o objeto, estabelecem-se as relações das partes e sua posição no todo. É assim que o percurso de investigação construído, que partiu do termo manifestante para investigar aquilo que o determina, revelou a posição relativa da repetição na teoria e determinou as relações que estabelece com os demais instrumentos teóricos. Definiu-se então sua posição no texto, bem como sua ligação necessária com as categorias da língua.

No excerto citado, Whitman sugere ainda uma recursividade em que a "prova" - no nosso caso, a análise - se repete, apontando para o procedimento que, para Hjelmslev (2003:11), nos levará à exaustividade. A continuidade da pesquisa nos fez chegar a três aspectos centrais que constroem a repetição sob estudo: a identificação, a saliência e a linearidade. Essa divisão da repetição mostra que há uma estrutura que está manifestada e, portanto, que a repetição está a serviço da construção do texto. Vai, nesse sentido, servir de "veículo" estrutural para a tensividade, o ritmo e o aspecto, o que quer dizer que sua presença nos textos está subordinada a esses elementos dirigentes do fluxo textual. Finalmente, porque está a serviço desse fluxo, podemos identificar certos modos ou estilos de progressão textual segundo as determinações criadas por meio da repetição, ou seja, segundo a repetição interfira no texto localmente, globalmente ou de forma mista, criando uma progressão que se assemelha à figura da espiral.

Estamos, por outro lado, conscientes do modesto alcance de nossa proposta geral e, sobretudo, dos limites específicos de cada parte. Para começar, 
no Capítulo 1, uma certa linguística e um certo aspecto da retórica nos ofereceram o contexto necessário para criarmos as oposições introdutórias de nossa perspectiva. No entanto, a linguística e a retórica que estão na base das distinções propostas por Frédéric podem ser muito mais elaboradas e trazer mais detalhes sobre conceitos que são apenas mencionados pela autora, como sentido próprio e figurado, que poderiam trazer mais pistas sobre o fenômeno. Ainda assim, o capítulo respeita seus propósitos, uma vez que dividimos o campo entre retórica, linguística e semiótica e essa comparação mostrou-se proveitosa na justificativa do caminho adotado. O Capítulo 2 também se depara com seus limites internos e sobretudo a ausência do conceito de conotação, brevemente mencionado no estudo linguístico-retórico, se faz sentir.

Os Capítulos 3 e 4 talvez encontrem mais continuidade entre si, mas a questão do aspecto não está mais que esboçada. Isso porque "a semiótica, divergindo de suas escolhas iniciais, terminou por conceder ao aspecto um alcance extraordinário, muito além de sua aplicação ao processo" (Zilberberg, 2011b:16). Mesmo na semiótica tensiva, o aspecto já recebeu inúmeras formulações: refere-se a limites e graus, formas de progressão textual, noções de abertura e fechamento, paradas e continuações. Assim, usamos aquilo que nos foi diretamente útil para descrever os meandros da repetição, mas apenas o exposto já sugere que ganharíamos com um estudo mais ordenado e detalhado. ${ }^{26}$

Por fim, no que toca o Capítulo 5, propusemos nossas análises como

\footnotetext{
${ }^{26}$ Renata Mancini (2006) propôs um lugar teórico para o aspecto na semiótica. Um estudo largo das diferentes concepções de aspecto em contraste com sua proposta seria um caminho possível.
} 
exemplos da atuação da repetição na economia geral dos textos. Entretanto, insistimos por toda a tese na extensão do fenômeno sob escrutínio e gostaríamos de acreditar que ele vai além do texto poético e cancional. Se teoricamente não há empecilho para um alargamento do escopo de aplicabilidade, a comprovação disso requer mais extensas análises de mais variados textos.

Reconhecidas as limitações, parece-nos ainda que atingimos nossa proposta para o tratamento da repetição e acreditamos ter encontrado o seu lugar teórico, suas condições e alguns desdobramentos. Nosso procedimento discursivo destacou, do ponto de vista amplo, o caráter opositivo, relacional e dinâmico da teoria semiótica, por meio da investigação do funcionamento da repetição. Por um lado, ao investigar a repetição nos quadros da semiótica, rediscutimos uma série de conceitos centrais à disciplina, das próprias concepções de semiótica e texto até a linearidade, o andamento e o aspecto, para citar apenas alguns. Por outro lado, o nosso trajeto eminentemente analítico reatualizou o procedimento semiótico e confirmou sua eficácia no estabelecimento de novos e antigos conceitos, além de realçar as relações entre as partes da teoria e o seu conjunto.

Por fim, o maior interesse de nosso exercício analítico está na própria virada de perspectiva que colocou a repetição no centro das investigações, uma vez que esclareceu certas contradições aparentes do fenômeno. A estrutura e o funcionamento da repetição permitiram entender de que maneira um mecanismo eminentemente circular acaba por criar uma direção 
ou como um procedimento átono cria um pico de tensão. O esvaziamento de sentido produzido pelo retorno incessante do mesmo no texto leva justamente ao seu oposto e, portanto, à criação de impacto e direção. Exatamente pelo fato de criar sentido onde parecia não haver nada, a repetição cria a ilusão da estrutura pura: do vazio criador do sentido. 


\section{Referências Bibliográficas}

ARrivÉ, Michel. “Diachronie et linéarité." Linx, (7), 1995.

URL http://linx.revues.org/1133

BADIR, Sémir. Hjelmslev. Figures du Savoir. Paris: Les Belles Lettres, 2000.

—. "La production de la sémiosis: Une mise au point théorique." Actes Sémiotiques, 2009.

URL http://epublications . unilim.fr/revues/as/3335

—. "Le texte: Objet théorique, objet empirique." In:JEANNERET, Yves \& MeEÙs, Nicolas (Orgs.), Que faisons-nous du texte?, p. 11-22. Paris: PUPS, 2012.

—. Épistémologie Sémiotique. Paris: Honoré Champion, 2014.

BARBOSA, João Alexandre. In: “Linguagem e metalinguagem em João Cabral". Metáfora Crítica. São Paulo: Perspectiva, 1974.

—. In: "Balanço de João Cabral". As Ilusões da Modernidade: Notas sobre a Historicidade da Lírica Moderna. São Paulo: Perspectiva, 1 ed., 2005.

BARros, Diana Luz Pessoa de. "Dialogismo, polifonia e enunciação." In:Dialogismo, Polifonia, Intertextualidade: Em Torno de Mikhail Bakhtin, p. 
1-9. Barros, Diana Luz Pessoa de and Fiorin, José Luiz, São Paulo: Edusp, 1994.

. Teoria do Discurso: Fundamentos Semióticos. São Paulo: Humanitas, 2 ed., 2001.

BARTHES, Roland. "L'ancienne rhétorique." Communications, vol. 16, 172$229,1970$.

Baudelaire, Charles. OEuvres complètes, vol. 1 of Coleção La Pléiade. Paris: Gallimard, 1975.

BENVENISTE, Émile. In: “Os níveis da análise linguística". vol. I, Problemas de Linguística Geral. Campinas: Pontes / Editora da Unicamp, 4 ed., 1995. Tradução de Maria da Glória Novak e Maria Luisa Neri.

BERTRAND, Denis. "L'expression rhétorique de la matière." In:AlONSO, Juan et al. (Org.), La Transversalité du sens: Parcours sémiotiques, p. 59-72. Saint-Denis: Presses Universitaires de Vincennes, 2006.

—. "La provocation figurative de la métamorphose." In:COLASBlaise, Marion \& Beyaert-Geslin, Anne (Orgs.), Le sens de la métamorphose, p. 161-173. Limoges: Pulim, 2009.

BISHOP, Elizabeth. The Complete Poems: 1927-1979. Nova York: Farrar, Straus and Giroux, 1984.

CAdiot, Pierre \& Visetti, Yves-Marie. Pour une théorie des formes sémantiques: Motifs, profils, thèmes. Paris: PUF, 2001. 
CHOI, Yong-Ho. Le temps chez Saussure. Tese de Doutorado, Université Paris X, Nanterre, 1996.

CortázAr, Julio. O Jogo da Amarelinha. Rio de Janeiro: Civilização Brasileira, 6 ed., 1999.

Cruz, Dilson Ferreira da. O Éthos dos Romances de Machado de Assis. São Paulo: Nankin / Edusp, 2009.

Deleuze, Gilles. Diferença e Repetição. Rio de Janeiro: Graal, 2 ed., 2006. Tradução de Luiz Orlandi e Roberto Machado.

Eliot, T. S. Complete Poems E Plays. Londres: Farber \& Farber, 2004.

FIORIN, José Luiz. Figuras de Retórica. São Paulo: Contexto, 2014.

FOnTANille, Jacques. “Identité." In:Greimas, Algirdas Julien \& COURTÉS, Joseph (Orgs.), Sémiotique : Dictionnaire raisonné de la théorie du langage, vol. Tomo 2, p. 109-110. Paris: Hachette, 1986.

—. "Textes, objets, situations et formes de vie: Les niveaux de pertinence du plan de l'expression dans une sémiotique des cultures." In:Alonso, J. et al. (Org.), La transversalité du sens: Parcours sémiotiques, p. 213-240. Saint-Denis: Presses Universitaires de Vincennes, 2006.

FREUD, Sigmund. In: “Recuerdo, repetición y elaboración". vol. 2, Obras Completas de Sigmund Freud. Madri: Biblioteca Nueva, 4 ed., 1981. Tradução de Luis Lopez-Ballesteros y de Torres.

FRÉDÉRIC, Madeleine. La répétition: Étude linguistique et rhétorique. Tübingen: Niemeyer, 1985. 
GenetTE, Gerard. "La rhétorique restreinte." Communications, vol. 16, 158-171, 1970.

GREIMAS, Algirdas Julien. In: "De la colère: étude de sémantique lexicale". Du sens II: essais sémiotiques. Paris: Seuil, 1983.

—. De l'imperfection. Périgueux, França: Pierre Fanlac, 1987.

Greimas, Algirdas Julien \& Courtés, Joseph. Dicionário de Semiótica. São Paulo: Contexto, 2011.

Grupo Mu. Retórica da Poesia: Leitura Linear, Leitura Tabular. São Paulo: Cultrix / Edusp, 1980.

GÉRARD, Christophe. "Sémantique et linéarité du texte: La place du rythme en sémantique des textes." Texto! Textes et Cultures, vol. 11(1), 2006.

URL http://www.revue \discretionary $\{-\}\{\}\{\}$ texto.net/Inedits/ Gerard/Gerard_Linearite.html

HARKOT-De LA-TAILle, Elizabeth. Ensaio Semiótico sobre a Vergonha. São Paulo: Humanitas, 1999.

HARKot-DE LA-TAille, Elizabeth \& TAILle, Yves de la. “Construção Ética e moral de si mesmo." In:Os Sentidos de Construção: o Si Mesmo e o Mundo, vol. 1, p. 69-101. Maria Thereza Costa Coelho de Souza, São Paulo: Casa do Psicólogo, 2004.

HJELMSLEV, Louis. In: "Por uma semântica estrutural". Ensaios Linguísticos. São Paulo: Perspectiva, 1991a. 
—. Le Langage. Paris: Gallimard, $1991 b$.

—. Prolegômenos a uma Teoria da Linguagem. Estudos. São Paulo: Perspectiva, 2 ed., 2003. Tradução de J. Teixeira Coelho Netto.

—. "Résumé d'une théorie du langage.", 2010. Tradução e edição eletrônica Alain Herreman.

URL http://resume.univ-rennes1.fr/

JAKOBSON, Roman. "Dois aspectos da linguagem e dois tipos de afasia." In:Linguística e Comunicação, p. 34-62. São Paulo: Cultrix, 2010.

LAKOfF, George \& Johnson, Mark. Metáforas da Vida Cotidiana. Campinas: Mercado de Letras, 2002.

LANDOWSKI, Eric. "Para uma semiótica do sensível." Educação e Realidade, vol. 2(30), 93-106, 2005.

—_. "Avant-propos: Ajustements stratégiques." Actes Sémiotiques, (110), 2007.

URL http://epublications. unilim.fr/revues/as/66

LEMOS, Carolina Lindenberg. Entre Expressões e Conteúdos: do Semissimbolismo às Categorias Tensivas. DissertaÃß̃̃̃o de Mestrado, Universidade de São Paulo, São Paulo, 2010.

—. "La temporalité et la négation dans le parcours interprétatif d'une installation de dany danino.", 2013.

LlORACH, Emilio A. Gramática Estrutural. Madrid: Gredos, 1972. 
LOPES, Marcos. "Semântica extensiva." In:CORTINA, Arnaldo \& MARCHEZAN, Renata Coelho (Orgs.), Razões e Sensibilidades: A Semiótica em Foco, p. 33-49. Araraquara / São Paulo: Laboratório Editorial - UNESP / Cultura Acadêmica, 2004.

LÉvi-Strauss, Claude. Antropologia Estrutural. Rio de Janeiro: Tempo Brasileiro, 1985.

Mancini, Renata Ciampone. Dinamização nos Níveis do Percurso Gerativo: Canção e Literatura Contemporânea. Tese de Doutorado, FFLCH - Universidade de São Paulo, São Paulo, 2006.

Melo Neto, João Cabral de. Serial e Antes. Rio de Janeiro: Nova Fronteira, 1997.

MoliniÉ, Georges. "Problématique de la répétition." Langue Française, vol. 101, 102-111, 1994.

Nunes, Benedito. João Cabral de Melo Neto. Petrópolis: Vozes, 1971.

PAZ, Octavio. O Arco e a Lira. São Paulo: Cosac Naify, 2012. Tradução de Ari Roitman e Paulina Wacht.

PoE, Edgard Allan. Complete Poems. Penguin, 1996.

PORTER, Cole. The Cole Porter Song book. Nova York: Simon and Schuster, 1959.

RASTIER, François. Sémantique interprétative. Formes sémiotiques. Paris: PUF, 3 ed., 2009. 
SAdIE, Stanley (Org.). Dicionário Grove de Música: Edição Concisa. Rio de Janeiro: Jorge Zahar, 1994. Tradução de Eduardo Francisco Alves.

SAussure, Ferdinand de. Curso de Linguística Geral. São Paulo: Cultrix, 1997. Tradução de Antônio Chelini, José Paulo Paes e Izidoro Blikstein.

SHAKeSPEARE, William. In: "Romeo and juliet". The Complete Works of William Shakespeare. Minneapolis: Amaranth Press, 1982.

—. The Sonnets. Londres: Leopard, 1996.

TALMY, Leonard. Toward a Cognitive Semantics, vol. Vol. 1. Boston: MIT Press, 2000.

TATIT, Luiz. Musicando a Semiótica: Ensaios. São Paulo: Annablume, 1 ed., 1997.

—. Análise Semiótica através das Letras. São Paulo: Ateliê, 2001.

—. "Abordagem do texto." In:FIORIN, José Luiz (Org.), Introdução à Linguística, vol. I. Objetos Teóricos, p. 187-209. São Paulo: Contexto, 2002.

—. Hjelmslev e as Bases Tensivas do Semi-simbolismo. São Paulo: Editora CPS, 1 ed., 2007a.

—. Semiótica da Canção: Melodia e Letra. São Paulo: Escuta, 3 ed., $2007 b$.

TestenOIRE, Pierre-Yves. "La linéarité saussurienne en rétrospection." Texto! Textes et Cultures, vol. XIX(2), 1-18, 2014.

VILlAÇA, Alcides. "Expansão e limite da poesia de João Cabral." In:Leitura de Poesia, p. 141-169. Alfredo Bosi, São Paulo: Ática, 2003. 
Whitman, Walt. Leaves of Grass. Filadélfia: David MacKay, 9 ed., 1891. URL http://www . whitmanarchive.org/published/LG/1891/poems/27

ZilberberG, Claude. "Figure." In:Greimas, Algirdas Julien \& COURTÉS, Joseph (Orgs.), Sémiotique: Dictionnaire raisonné de la théorie du langage, vol. Tomo II, p. 91-93. Paris: Hachette, 1986.

—. "Plaidoyer pour le tempo." In:FOnTANille, Jacques (Org.), Le Devenir, p. 223-241. Limoges: Pulim, 1995.

—_. "Rythme et générativité." Études littéraires, vol. 29(1), 21-38, 1996. URL http://id.erudit.org/iderudit/501144ar

—. "Esquisse d'une grammaire du sublime chez Longin." Langages, vol. 137(34), 102-121, 2000.

—. "Le double conditionnement — tensif et rhétorique — des structures élémentaires de la signification." In:AlONSO, J. et al. (Org.), La transversalité du sens: Parcours Sémiotiques, p. 35-45. Saint-Denis: Presses Universitaires de Vincennes, $2006 a$.

—. Razão e Poética do Sentido. São Paulo: Edusp, 2006b. Tradução de Ivã Carlos Lopes, Luiz Tatit e Waldir Beividas.

_. "Pour saluer l'événement." Actes Sémiotiques, (111), 2008.

URL http://epublications.unilim.fr/revues/as/1601

—. "Observações sobre a base tensiva do ritmo." Estudos Semióticos, vol. 6(2), 1-13, 2010. Tradução de Lucia Teixeira e Ivã Carlos Lopes.

URL http://www.revistas.usp.br/esse/article/view/49265/53347 
—. Des Formes de vie aux valeurs. Paris: PUF, 1 ed., 2011 a.

—. Elementos de Semiótica Tensiva. São Paulo: Ateliê, 2011b. Tradução de Ivã Carlos Lopes, Luiz Tatit e Waldir Beividas.

- La Structure tensive suivi de Note sur la structure des paradigmes et de Sur la dualité de la poétique. Liège: Presses Universitaires de Liège, 2012. ZinnA, Alessandro. "Linéarité et devenir." In:FontAnILle, Jacques (Org.), Le Devenir: Actes du colloque Linguistique et Sémiotique III, p. 243-264. Limoges: Pulim, 1995. 
Anexo I

Poema(s) da Cabra 


\section{POEMA(S) DA CABRA}

(Nas margens do Mediterrâneo

não se vê um palmo de terra

que a terra tivesse esquecido

de fazer converter em pedra.

Nas margens do Mediterrâneo

Não se vê um palmo de pedra

que a pedra tivesse esquecido

de ocupar com sua fera.

Ali, onde nenhuma linha

pode lembrar, porque mais doce,

o que até chega a parecer

suave serra de uma foice,

não se vê um palmo de terra

por mais pedra ou fera que seja,

que a cabra não tenha ocupado

com sua planta fibrosa e negra.)

1 A cabra é negra. Mas seu negro

não é o negro do ébano douto

(que é quase azul) ou o negro rico

do jacarandá (mais bem roxo).

O negro da cabra é o negro 
do preto, do pobre, do pouco.

Negro da poeira, que é cinzento.

Negro da ferrugem, que é fosco.

Negro do feio, às vezes branco.

Ou o negro do pardo, que é pardo.

Disso que não chega a ter cor

ou perdeu toda cor no gasto.

É o negro da segunda classe.

Do inferior (que é sempre opaco).

Disso que não pode ter cor

porque em negro sai mais barato.

2 Se o negro quer dizer noturno

o negro da cabra é solar.

Não é o da cabra o negro noite.

É o negro de sol. Luminar.

Será o negro do queimado

mais que o negro da escuridão.

Negra é do sol que acumulou.

É o negro mais bem do carvão.

Não é o negro do macabro.

Negro funeral. Nem do luto.

Tampouco é o negro do mistério,

de braços cruzados, eunuco. 
É mesmo o negro do carvão.

O negro da hulha. Do coque.

Negro que pode haver na pólvora:

negro de vida, não de morte.

3 O negro da cabra é o negro

da natureza dela cabra.

Mesmo dessa que não é negra,

como a do Moxotó, que é clara.

O negro é o duro que há no fundo

da cabra. De seu natural.

Tal no fundo da terra há pedra,

no fundo da pedra, metal.

O negro é o duro que há no fundo

da natureza sem orvalho

que é a da cabra, esse animal

sem folhas, só raiz e talo,

que é a da cabra, esse animal

de alma-caroço, de alma córnea,

sem moelas, úmidos, lábios,

pão sem miolo, apenas côdea.

4 Quem já encontrou uma cabra

que tivesse ritmos domésticos?

O grosso derrame do porco, 
da vaca, de sono e de tédio?

Quem encontrou cabra que fosse animal de sociedade?

Tal o cão, o gato, o cavalo, diletos do homem e da arte?

A cabra guarda todo o arisco, rebelde, do animal selvagem, viva demais que é para ser animal dos de luxo ou pajem. Viva demais para não ser, quando colaboracionista, o reduzido irredutível, o inconformado conformista.

5 A cabra é o melhor instrumento de verrumar a terra magra. Por dentro da serra e da seca nada chega onde chega a cabra.

Se a serra é terra, a cabra é pedra. Se a serra é pedra, é pedernal. Sua boca é sempre mais dura que a serra, não importa qual. A cabra tem o dente frio, 
a insolência do que mastiga.

Por isso o homem vive da cabra

mas sempre a vê como inimiga.

Por isso quem vive da cabra

e não é capaz do seu braço

desconfia sempre da cabra:

diz que tem parte com o Diabo.

6 Não é pelo vício da pedra,

por preferir a pedra à folha.

É que a cabra é expulsa do verde,

trancada do lado de fora.

A cabra é trancada por dentro.

Condenada à caatinga seca.

Liberta, no vasto sem nada,

proibida, na verdura estreita.

Leva no pescoço uma canga

que a impede de furar as cercas.

Leva os muros do próprio cárcere:

prisioneira e carcereira.

Liberdade de fome e sede

da ambulante prisioneira.

Não é que ela busque o difícil:

é que a sabem capaz de pedra. 
7 A vida da cabra não deixa

lazer para ser fina ou lírica

(tal o urubu, que em doces linhas

voa à procura da carniça).

Vive a cabra contra a pendente, sem os êxtases das descidas.

Viver para a cabra não é

re-ruminar-se introspectiva.

É, literalmente, cavar

a vida sob a superfície,

que a cabra, proibida de folhas,

tem de desentranhar raízes.

Eis por que é a cabra grosseira,

de mãos ásperas, realista.

Eis porque, mesmo ruminando,

não é jamais contemplativa.

8 O núcleo de cabra é visível

por debaixo de muitas coisas.

Com a natureza da cabra

outras aprendem sua crosta.

Um núcleo de cabra é visível

em certos atributos roucos

que têm as coisas obrigadas 
a fazer de seu corpo couro.

A fazer de seu couro sola,

a armar-se em couraças, escamas:

como se dá com certas coisas

e muitas condições humanas.

Os jumentos são animais

que muito aprenderam com a cabra.

O nordestino, convivendo-a,

fez-se de sua mesma casta.

9 O núcleo de cabra é visível

debaixo do homem do Nordeste.

Da cabra lhe vem o escarpado

e o estofo nervudo que o enche.

Se adivinha o núcleo de cabra

no jeito de existir, Cardozo,

que reponta sob seu gesto

como esqueleto sob o corpo.

E é outra ossatura mais forte

que o esqueleto comum, de todos;

debaixo do próprio esqueleto,

no fundo centro de seus ossos.

A cabra deu ao nordestino 
esse esqueleto mais de dentro:

o aço do osso, que resiste

quando o osso perde seu cimento.

(O Mediterrâneo é mar clássico, com águas de mármore azul.

Em nada me lembra das águas sem marca do rio Pajeú.

As ondas do Mediterrâneo

estão no mármore traçadas.

Nos rios do Sertão, se existe,

a água corre despenteada.

As margens do Mediterrâneo

parecem deserto balcão.

Deserto, mas de terras nobres

não da piçarra do Sertão.

Mas não minto o Mediterrâneo

nem sua atmosfera maior

descrevendo-lhe as cabras negras

em termos da do Moxotó.)

Melo Neto (1997 : 239-245) 
Anexo II

Miss Otis Regrets 


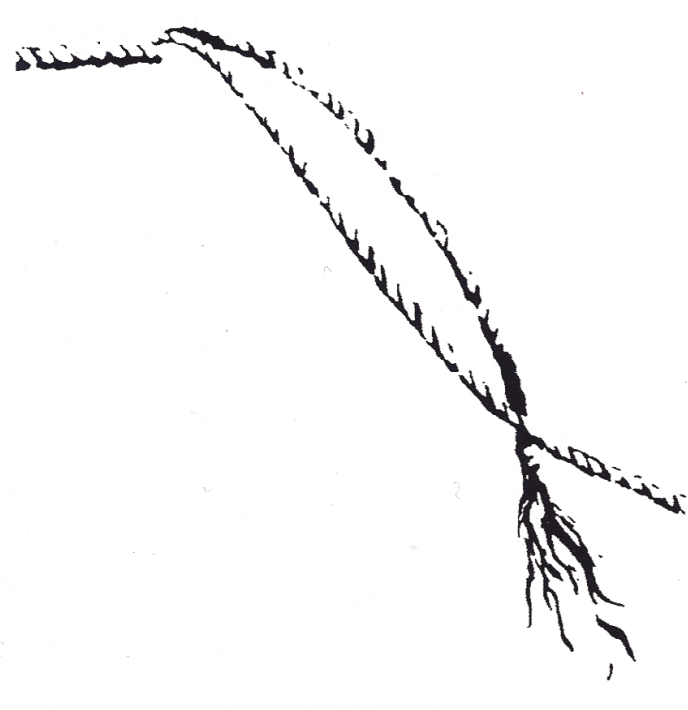

\section{Miss Otis Regrets}

1934
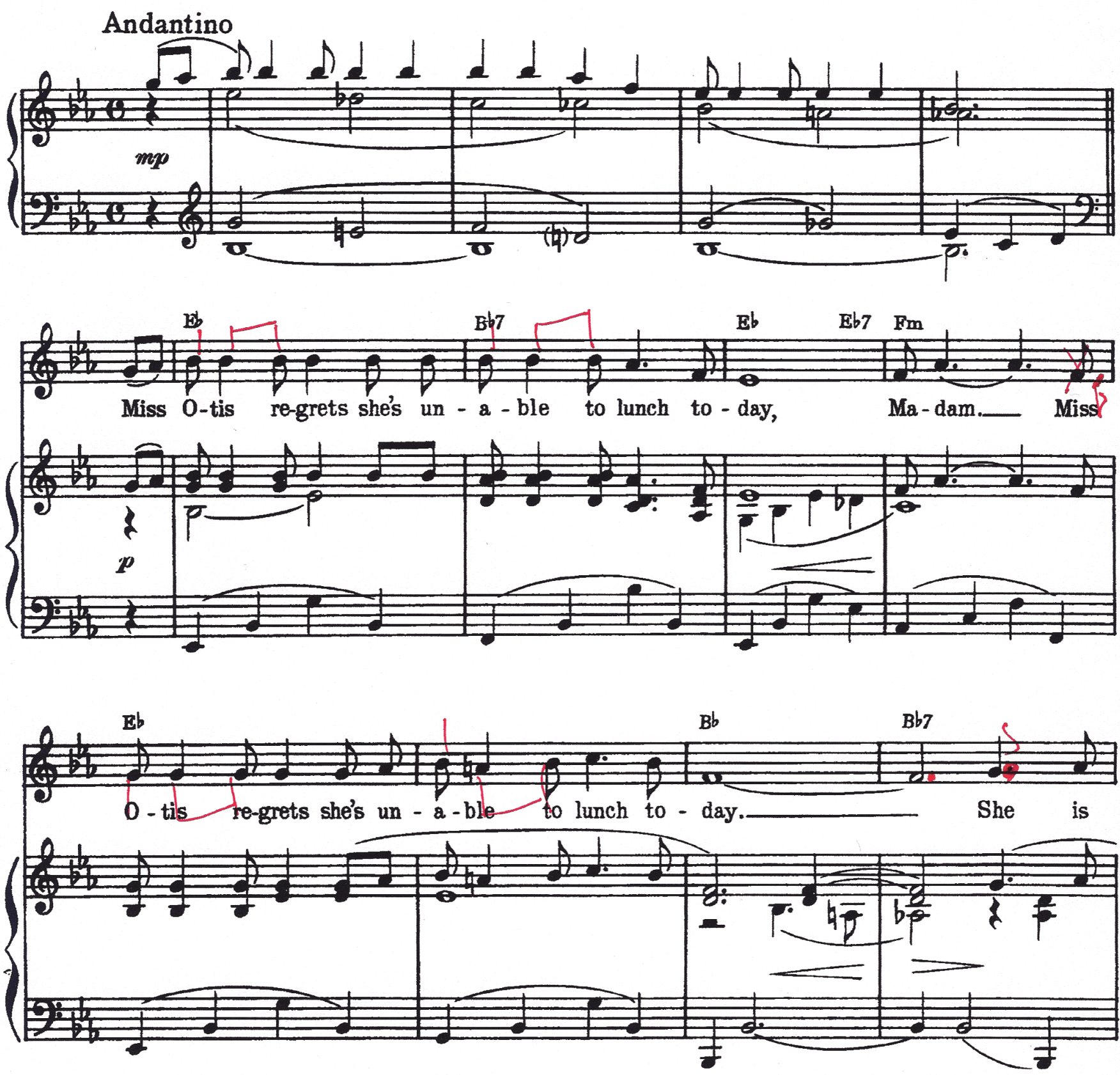

Copyright 1984 by HARMS, INC. 
single cford,
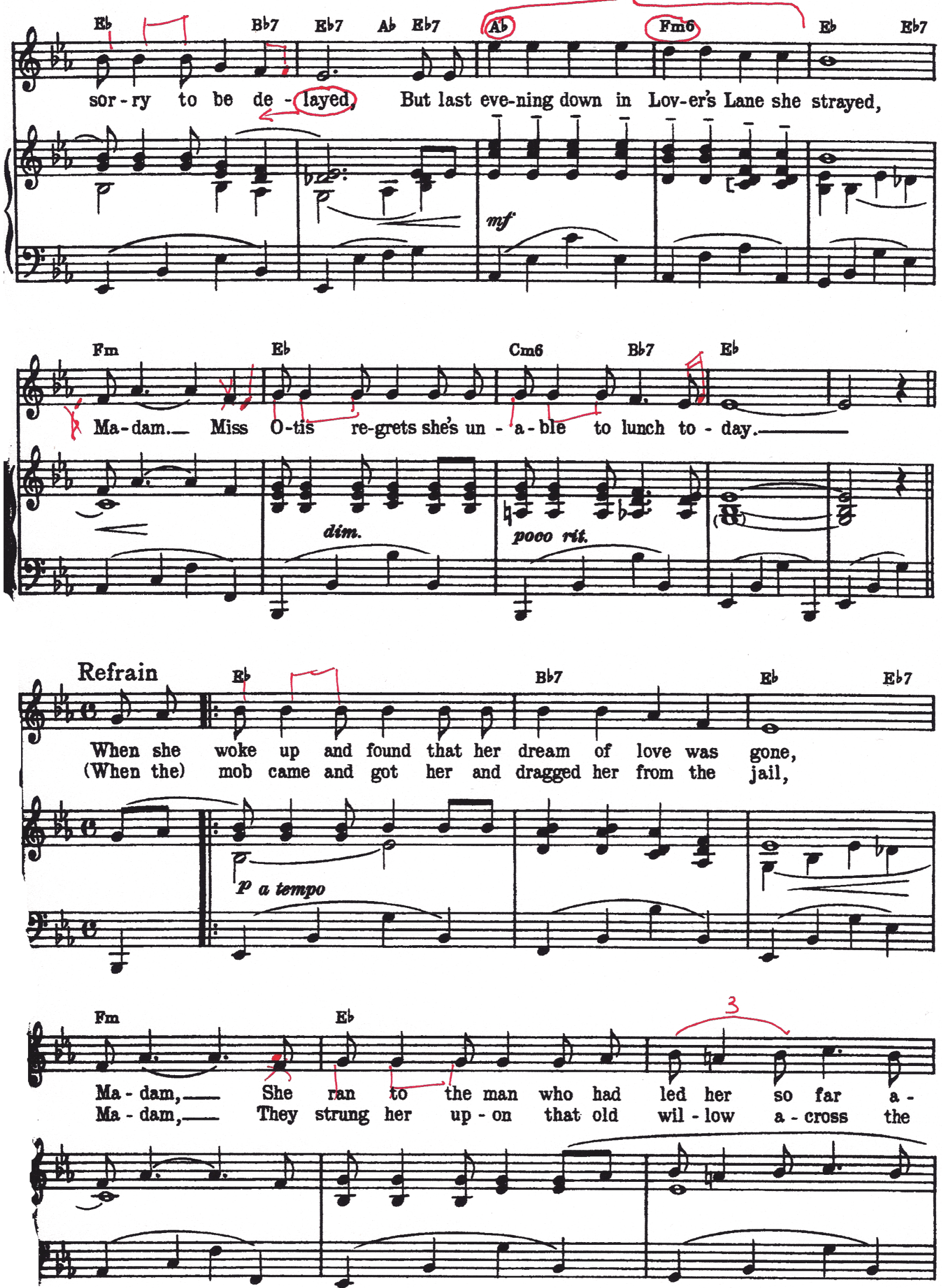

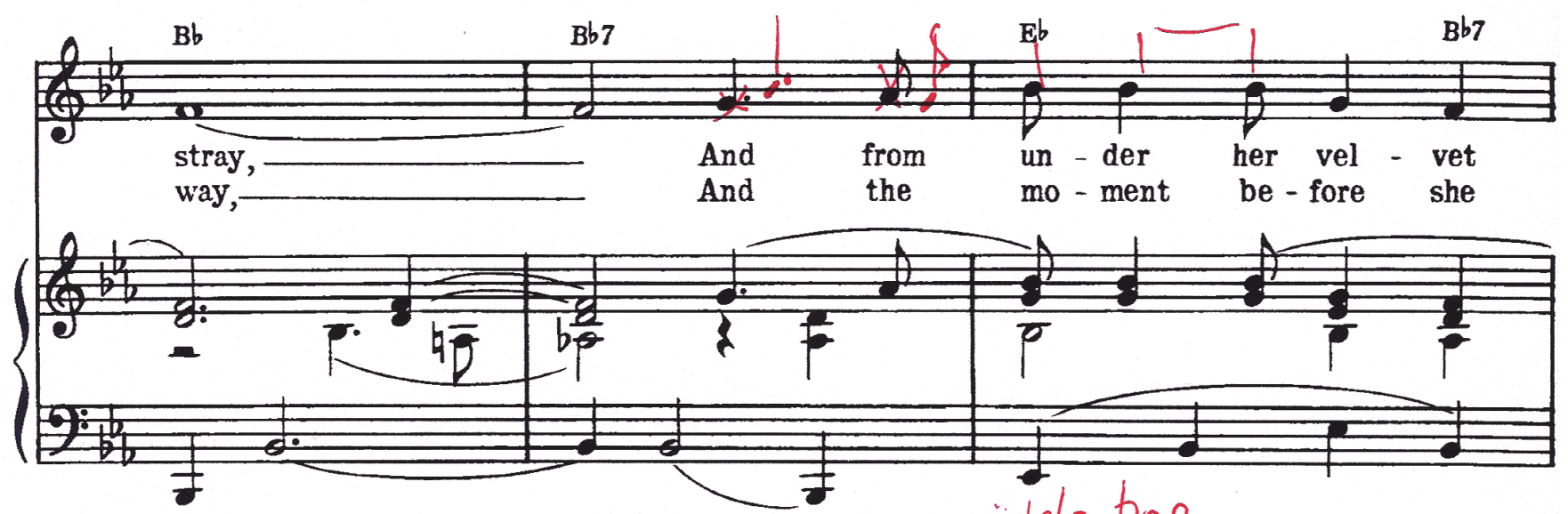

$$
\text { single boe }
$$
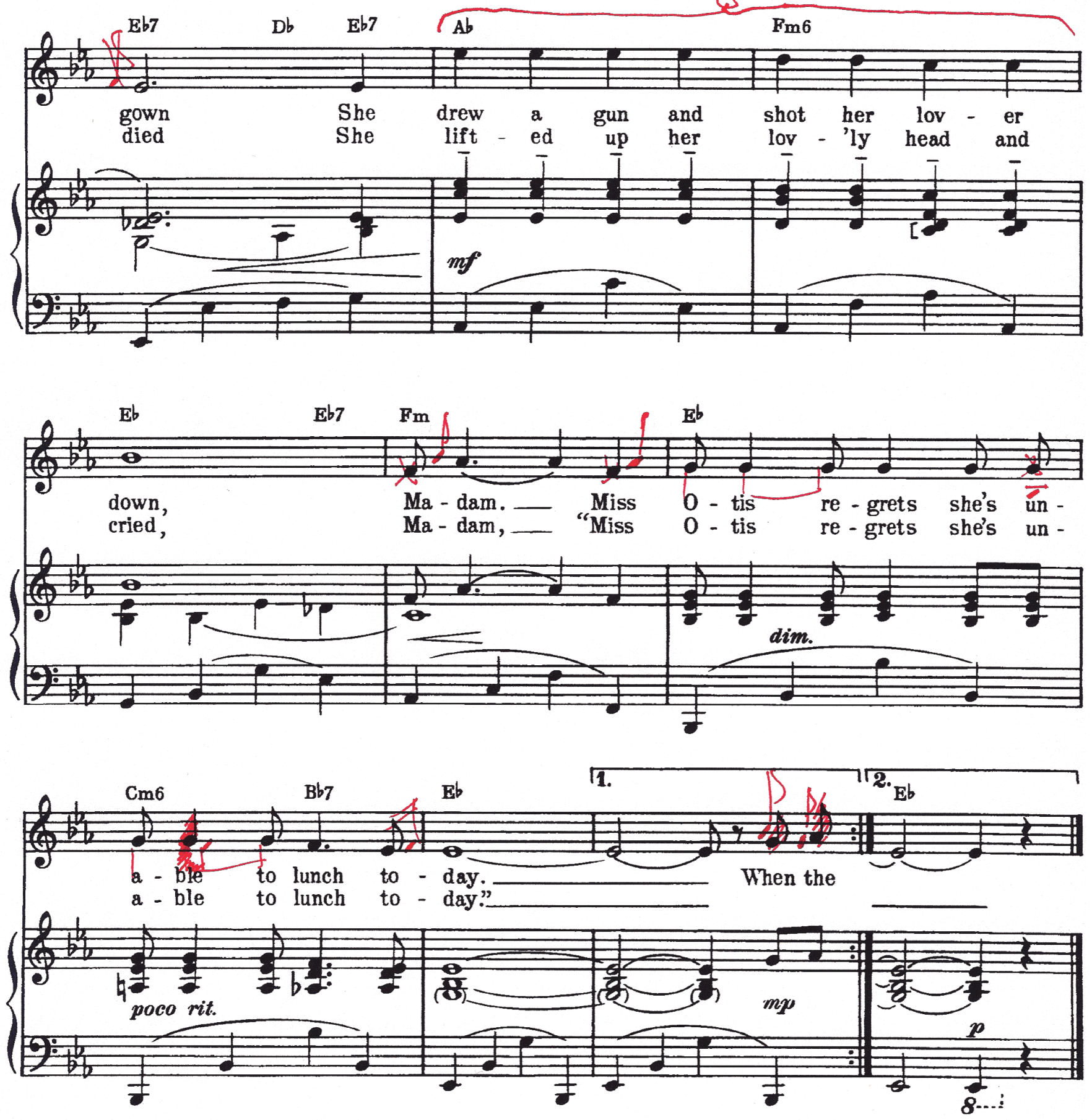

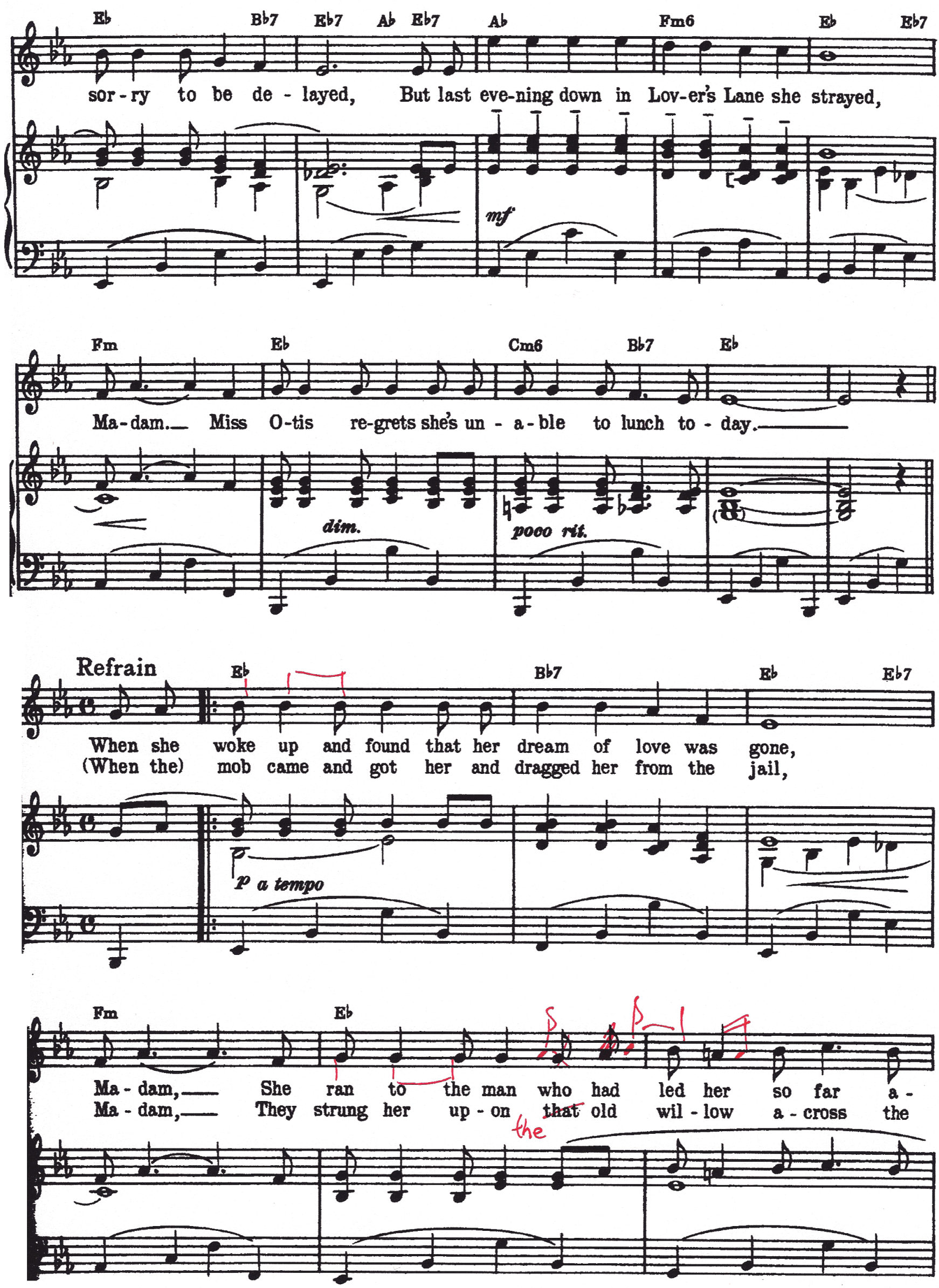

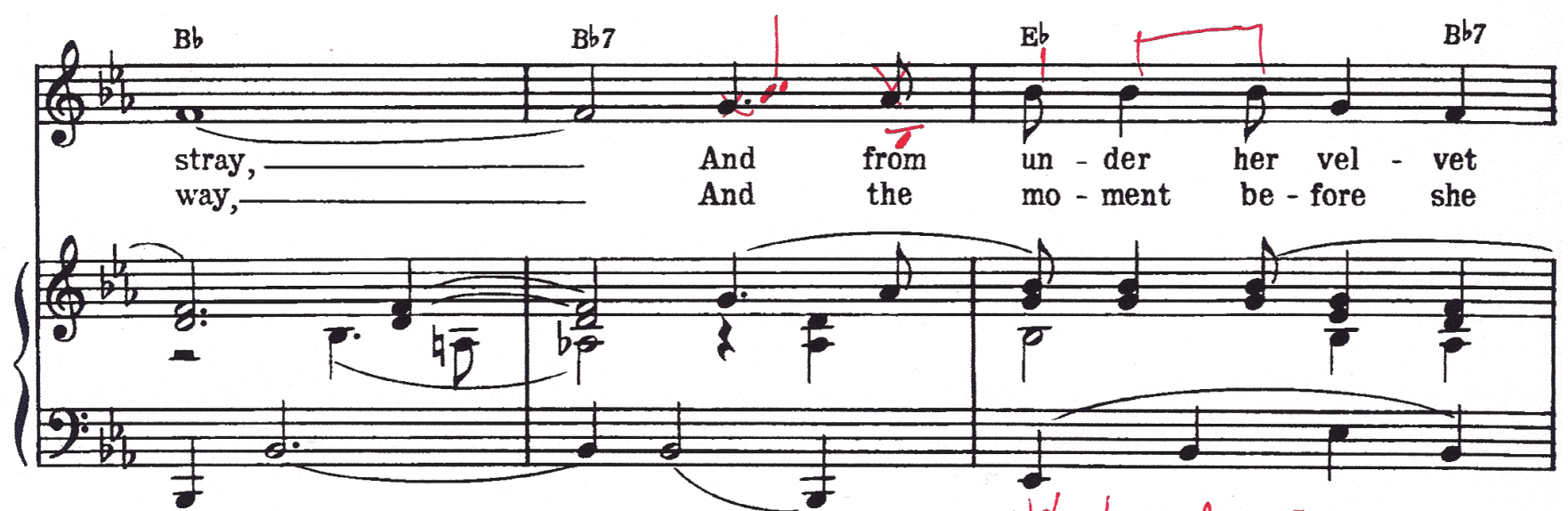

single bor, slower
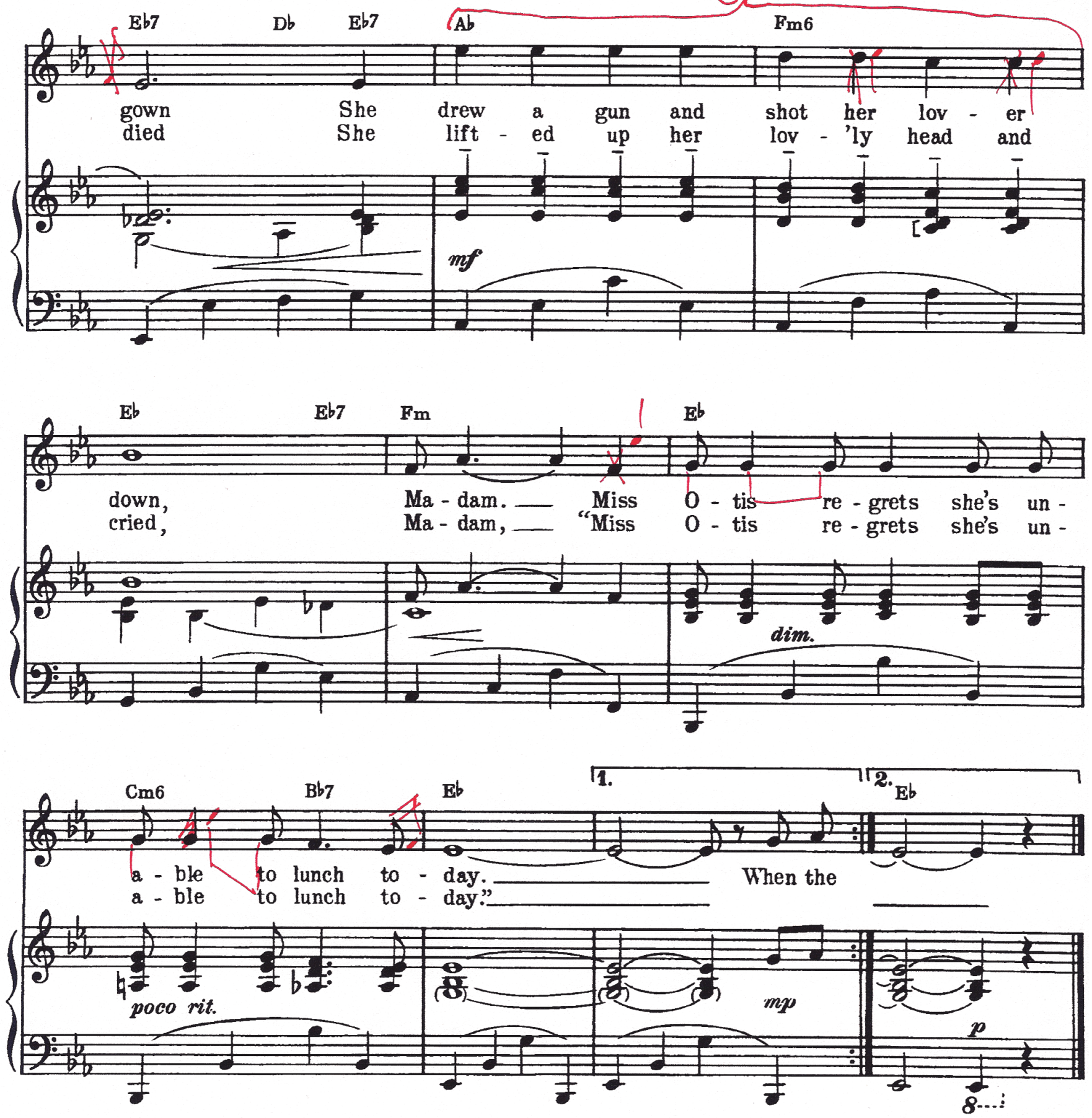


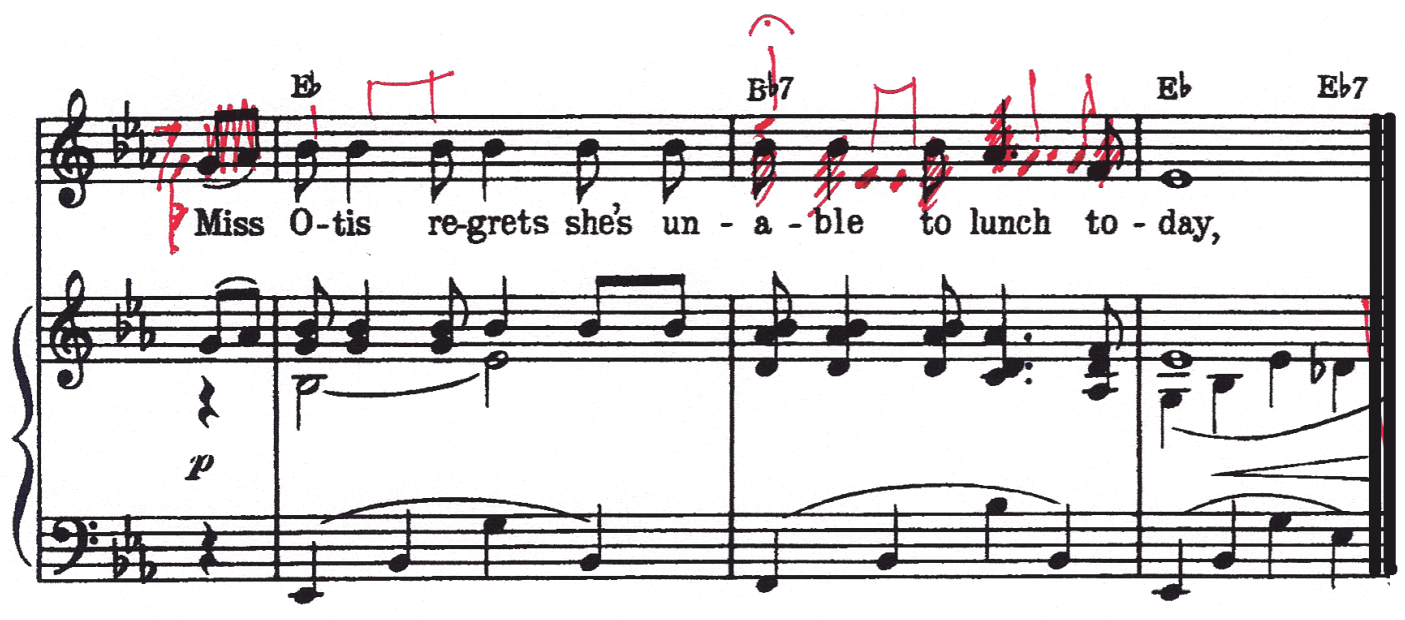

